\title{
MICHELI MEDEIROS
}

\section{Padronização de teste molecular para o diagnóstico de meningites bacterianas pós-neurocirurgia}

Tese apresentada à Faculdade de Medicina da Universidade de São Paulo para a obtenção do título de Doutor em Ciências

Programa de Doenças Infecciosas e Parasitárias

Orientadora: Prof. Dra. Anna Sara Shafferman Levin

(Versão corrigida. Resolução CoPGr 6018/11, de 1 de Novembro de 2011. A versão original está disponível na Biblioteca da FMUSP)

São Paulo 


\section{MICHELI MEDEIROS}

\section{Padronização de teste molecular para o diagnóstico de meningites bacterianas pós-neurocirurgia}

Tese apresentada à Faculdade de Medicina da Universidade de São Paulo para a obtenção do título de Doutor em Ciências

Programa de Doenças Infecciosas e Parasitárias

Orientadora: Prof. Dra. Anna Sara Shafferman Levin

(Versão corrigida. Resolução CoPGr 6018/11, de 1 de Novembro de 2011. A versão original está disponível na Biblioteca da FMUSP)

São Paulo 


\section{Dados Internacionais de Catalogação na Publicação (CIP)}

Preparada pela Biblioteca da

Faculdade de Medicina da Universidade de São Paulo

\section{Creprodução autorizada pelo autor}

Medeiros, Micheli

Padronização de teste molecular para o diagnóstico

de meningites bacterianas pós-neurocirurgia /

Micheli Medeiros. -- São Paulo, 2018.

Tese(doutorado)--Faculdade de Medicina da

Universidade de São Paulo.

Programa de Doenças Infecciosas e Parasitárias.

Orientadora: Anna Sara Shafferman Levin.

Descritores: 1.Meningite 2.Infecção 3.Craniotomia 4. Iíquido cefalorraquidiano 5.Diagnóstico 6.RNA

ribossômico $16 \mathrm{~s}$ 7.Análise de sequência

$\mathrm{USP} / \mathrm{FM} / \mathrm{DBD}-328 / 18$

Responsável: Eidi Raquel Franco Abdalla - CRB-8/4901 
Dedico esta tese à minha avó materna Elvira, aos meus pais Hamilton e Judith.

E aos meus sobrinhos Letícia, Arthur, Bernardo, Manuela e Cecília fica o exemplo de que é necessário dedicação e persistência para atingir os objetivos traçados. 


\section{AGRADECIMENTOS}

A Deus por permitir que eu desenvolvesse este trabalho por completo.

A minha orientadora Prof. Dra Anna Sara Shafferman Levin pelo apoio, incentivo, paciência, pelo exemplo de profissionalismo e acima de tudo pela oportunidade de aprendizado.

A Prof. Dra Silvia Figueiredo Costa pelo apoio técnico científico, por toda atenção e incentivo com o andamento do projeto.

Aos meus pais Hamilton e Judith, meus exemplos de vida, pelo incentivo, amor incondicional e apoio mesmo à distância, em todas as etapas desta pesquisa.

Aos meus irmãos Rodrigo e Fabrício, cunhadas Roberta e Fabiane juntamente com: Letícia, Arthur, Bernardo, Manuela e Cecília (os sobrinhos mais lindos do mundo) pelo carinho, apoio e momentos em família.

Helena pelo convívio tranquilo e saudável.

Aos colegas de laboratório, esta segunda família LIM 54, por todo o apoio e colaboração em todas as fases com este trabalho: Andréia, Ana Paula, Camila, Diego, Gaspar, Juliana, Sânia, Tatiana, Taniela e Victor. Em especial Lauro, Roberta e Débora pelo tempo dedicado e pelas sugestões valiosíssimas.

Ao LIM 46 coordenado pela Dra Ester Sabino, pela colaboração neste projeto, em especial aos alunos: Marcela, Flávia, Natália e Lucas.

Às funcionárias da Pró-sangue: Suzete e Anna por toda a atenção, aprendizado técnico científico e apoio no projeto. 
Ao Dr. Manoel Jacobsen Teixeira, chefe da Divisão de Clínica Neurocirúrgica do (ICHCFMUSP), que permitiu o desenvolvimento do projeto no setor de neurocirurgia.

Ao Dr. Hélio Rodrigues Gomes, responsável técnico do laboratório de Líquor, pela colaboração com o projeto.

Ao Dr. Ícaro Boszczoski (SCIH-IC), Dra. Denise Brandão (SCIH-IPq), Dr. Luiz Marcelo Sá Malbouisson (UTI Emergências Cirúrgicas e Trauma - IC) Dra. Maria José Carvalho Carmona (Anestesiologia - IC) pela colaboração e envolvimento com o projeto

Aos enfermeiros, residentes e médicos assistentes: da neurologia do Instituto de Psiquiatria, da UTI neurocirurgia, UTI traumatologia e Anestesiologia em especial a Carla Heleno Mollaco e Ana Natiele Barros por toda a ajuda e comprometimento na coleta do material estudado.

A Dr. José Ernesto Vidal, Prof. Dr. Robson Francisco de Souza e Dra. Thais Guimarães pelas sugestões propostas no exame de qualificação.

A Faculdade de Medicina da Universidade de São Paulo e ao Departamento de Moléstias Infecciosas e Parasitárias pela oportunidade de realizar o curso de pósgraduação.

As secretarias de Pós-graduação e do Departamento de Moléstias Infecciosas e Parasitárias, em especial a Roseli Santo, (que é uma santa) pela amizade, pelo apoio e atenção em todas as etapas.

A Capes pela bolsa concedida. 
Nobody said it was easy

No one ever said it would be this hard

Take me back to the start."

(The Scientist, Coldplay)

"Talvez não tenha conseguido fazer o melhor, mas lutei para que o melhor fosse feito. Não sou o que deveria ser, mas Graças à Deus, não sou o que era antes". (Marthin Luther King) 
Esta tese está de acordo com as seguintes normas, em vigor no momento desta publicação:

Referências: adaptado de International Committee of Medical Journals Editors (Vancouver).

Universidade de São Paulo. Faculdade de Medicina. Divisão de Biblioteca e Documentação. Guia de apresentação de dissertações, teses e monografias.

Elaborado por Anneliese Carneiro da Cunha, Maria Julia de A. L. Freddi, Maria F. Crestana, Marinalva de Souza Aragão, Suely Campos Cardoso, Valéria Vilhena. 3a ed. São Paulo: Divisão de Biblioteca e Documentação; 2011.

Abreviaturas dos títulos dos periódicos de acordo com List of Journals Indexed in Index Medicus. 
Este trabalho foi realizado no Hospital das Clínicas da Universidade de São Paulo e no Laboratório de Investigação Médica - 54 da Divisão de Moléstias Infecciosas da Faculdade de Medicina da Universidade de São Paulo com o auxílio financeiro ao aluno dado pela Coordenação de Aperfeiçoamento de Pessoal de Nível Superior (CAPES). 


\section{Sumário}

Lista de siglas e símbolos

Lista de tabelas

Lista de figuras

Resumo

Abstract

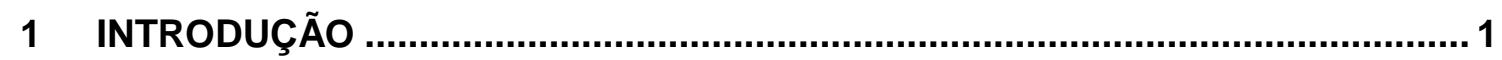

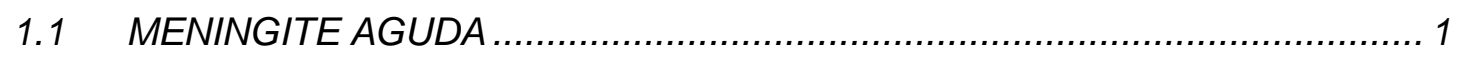

1.1.1 Meningite viral aguda ....................................................................... 1

1.1.2 Meningite bacteriana aguda adquirida na comunidade ........................ 4

1.1.3 Meningite bacteriana aguda hospitalar ……………………………….... 4

1.1.3.1 Agentes etiológicos encontrados na MAN.............................................. 5

1.1.3.2 Epidemiologia da MAN ........................................................................ 6

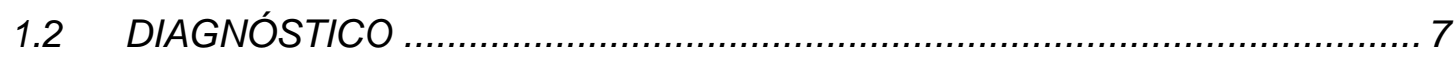

1.2.1 Diagnóstico convencional ...................................................................

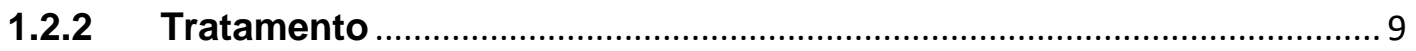

1.2.3 Diagnóstico complementar …………………………………………. 9

1.2.3.1 Reação em Cadeia da Polimerase (PCR) ........................................... 10

1.2.3.2 Reação em Cadeia da Polimerase em Tempo Real (RT-PCR)............ 11

1.2.3.3 Sequenciamento genético...................................................................... 11

1.3 ESTUDO DO RNA RIBOSSOMAL PROCARIÓTICO …............................. 12

1.3.1. Gene 16S DNA ribossomal............................................................... 13

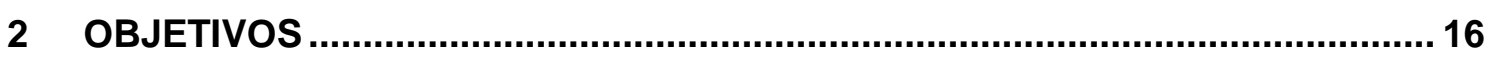

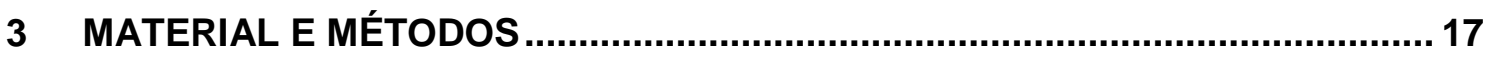

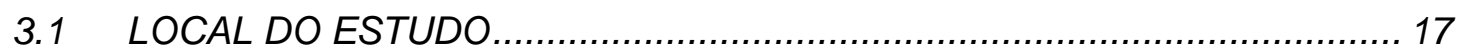

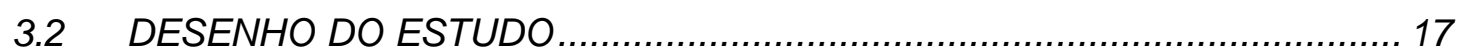

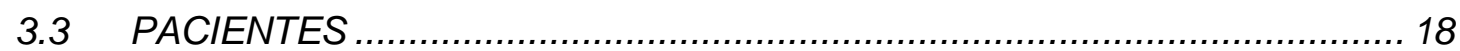

3.4 PADRONIZAÇÃO DO TESTE DE BIOLOGIA MOLECULAR PARA DIAGNÓSTICO DE MAN EM AMOSTRAS DE LCR INOCULADAS COM

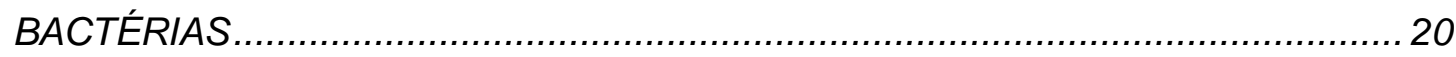

3.4.1 Validação da simplicação do gene 16S rRNA ………………………..... 20

3.4.2 Preparo das suspensões de microrganismos ......................................... 21 


\subsubsection{Extração e purificação de DNA, PCR para o gene 16S RNA}

ribossomal e eletroforese

3.4.4 Purificação das amostras e sequenciamento de Sanger ..................... 23

3.4.5 Análise das amostras sequenciadas ........................................................ 23

3.5 APLICAÇÃO DO MÉTODO DE BIOLOGIA MOLECULAR PARA

DIAGNÓSTICO DE MAN EM LCR DE PACIENTES SUBMETIDOS A

NEUROCIRURGIAS

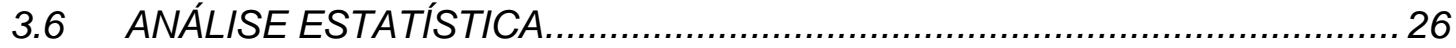

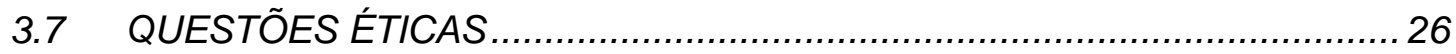

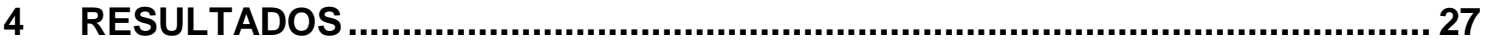

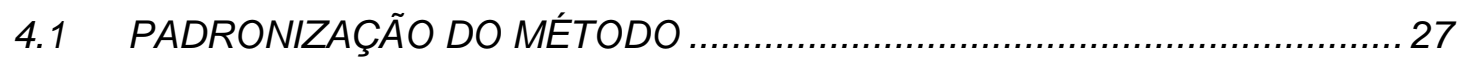

4.1.1 Validação da amplificação do gene 16S rRNA ……............................... 27

4.1.2 Determinação dos limites de detecção do método de biologia

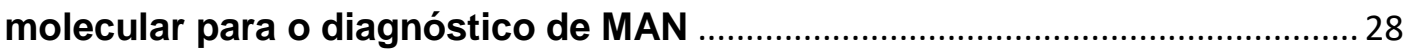

4.2 DADOS CLÍNICO-LABORATORIAIS DOS PACIENTES ............................ 29

4.3 APLICAÇÃO DO MÉTODO DE BIOLOGIA MOLECULAR EM AMOSTRAS DE LCR DE PACIENTES COM SUSPEITA DE MAN...................................... 33

4.4 COMPARAÇÃO DOS RESULTADOS DAS PCR POSITIVAS COM AS PCR NEGATIVAS DOS PACIENTES SUBMETIDOS A NEUROCIRURGIA .................. 36

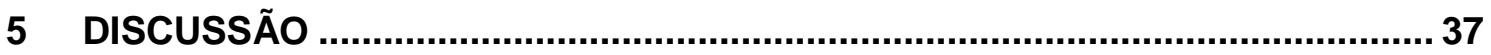

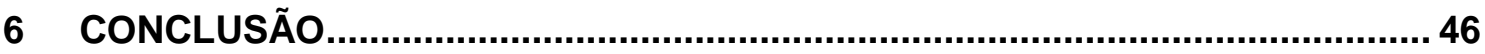

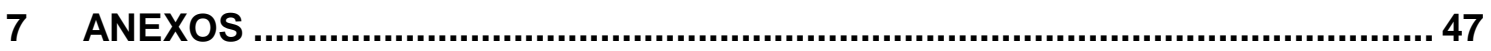

ANEXO A - Ficha Clínica desenvolvida para a pesquisa ................................. 47

ANEXO B - Parecer consubstanciado do Comitê de Ética.................................... 50

ANEXO C - Termo de consentimento livre e esclarecido aplicado na pesquisa...... 53

ANEXO D - Dados analisados dos pacientes submetidos a neurocirurgia e das

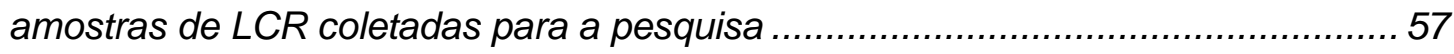

ANEXO E - Dificuldades enfrentadas durante a padronização e metodologias

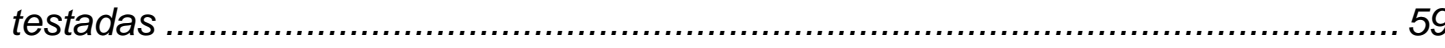

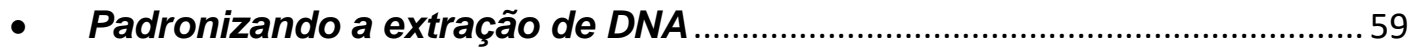

- Padronizando a reação de PCR do 16S RNA ribossomal............................ 59

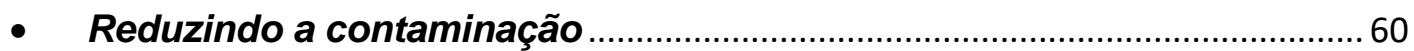

- Sequenciamento de nova geração Plataforma lon Torrent PGM ............... 60

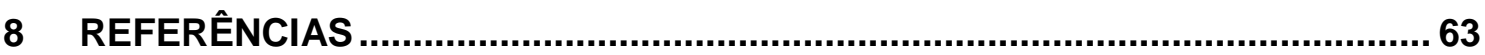




\section{LISTA DE SIGLAS E SÍMBOLOS}

ATCC

BLAST

CAPPesq

céls $/ \mathrm{mm}^{3}$

CDC/NHSN

DLC-HC

FMUSP

HC-FMUSP

HPN

ICHC

$\mathrm{IPq}$

LCR

LIM

MAN

MB

$\mathrm{mg} / \mathrm{dL}$

NCBI

NGS

PBS

PCR

RNA

rRNA
American Type Culture Collection

Basic Local Alignment Search Tool

Comissão de ética para análise de projetos de pesquisa

Células por milímetro cúbico

Centers for Disease Control and Prevention/The National Healthcare Safety Network

Departamento de Laboratório Central do Hospital das Clínicas

Faculdade de Medicina da Universidade de São Paulo

Hospital de Clínicas da Faculdade de Medicina da Universidade de São Paulo

Hidrocefalia de pressão normal

Instituto Central do Hospital das Clínicas

Instituto de Psiquiatria

Líquido cefalorraquidiano

Laboratório de Investigação Médica

Meningite após neurocirurgia

Meningite bacteriana

Miligramas por decilitro

National Center of Biotechnology Information

Sequenciamento de nova geração

Tampão fosfato-salino

Reação em cadeia polimerase

Ácido ribonucleico

Ácido ribonucleico ribossomal 
RT-PCR

SNC

TCLE

$\mathrm{UFC} / \mathrm{mL}$

UTI

$\mu \mathrm{L}$
Reação em Cadeia da Polimerase em Tempo Real

Sistema nervoso central

Termo de consentimento livre e esclarecido

Unidades formadoras de colônia por mililitro

Unidades de Terapia Intensiva

Microlitros 


\section{LISTA DE TABELAS}

Tabela 1 - Clafissificação da meningite aguda de acordo com o tipo de agente infeccioso, faixa etária do paciente e microrganismos associados 3

Tabela 2 - Principais agentes etiológicos relacionados aos fatores de predisposição a infecção pós-neurocirurgia

Tabela 3 - Sequência de nucleotídeos padronizados para a reação em cadeia da polimerase (PCR) 16S rRNA 20

Tabela 4 - Classificação de 51 pacientes expostos e não expostos a neurocirurgia, com relação à probabilidade de apresentarem meningite 30

Tabela 5 - Microrganismos mais prováveis encontrados no líquido cefalorraquidiano (LCR) de 51 pacientes expostos e não expostos à neurocirurgia identificados no sequenciamento pelo software BioEdit.

Tabela 6 - Comparação entre os parâmetros quimiocitológicos do líquido cefalorraquidiano (LCR) de amostras com resultado da reação em cadeia da polimerase (PCR) positiva e negativa 36 


\section{LISTA DE FIGURAS}

Figura 1 - Classificações taxonômicas propostas por Whittaker em 1969 e Woese em 1990.

Figura 2 - Regiões variáveis do RNA ribossomal 16S. Cada região variável no RNA ribossomal 16S está representada por uma cor diferente. As regiões V1 e V2 está em cor vermelha; V3 em laranja; V4 em amarelo; V5 e V6 e verde; V7 e V8 em azul e V9 em roxo

Figura 3 - Eletroforese em gel de agarose 1,5\% dos produtos de PCR para 16S rRNA, utilizando os primers 331F e 767R. Colunas: 1) peso molecular de 100 pares de base (Invitrogen® Thermo Fisher Scientific); 2) controle negativo (somente reagentes); 3) controle positivo (DNA bacteriano obtido de cultura pura); 4 a 9) amostras negativas; 10 e 11) amostra positiva (LCR com cultura bacteriana positiva; 12) peso molecular 100 pares de base (Invitrogen® Thermo Fisher Scientific).

Figura 4 - Limite de detecção para o kit de extração e purificação MagNa Pure Compact Nucleic Acid Isolation Kit; PCR para 16S rRNA, utilizando os primers 331F e 767R. Eletroforese em gel de agarose 1,5\% dos produtos de PCR. (A) Escherichia coli ATCC25922/ Colunas: PM) peso molecular 100 pares de base (Invitrogen® Thermo Fisher Scientific); 1) controle negativo mix; 2) amostra LCR puro; 3) amostra $10^{5}$ UFC/mL; 4) amostra $10^{4} \mathrm{UFC} / \mathrm{mL}$; 5) amostra $10^{3} \mathrm{UFC} / \mathrm{mL}$; 6) amostra $10^{2} \mathrm{UFC} / \mathrm{mL}$; 7) amostra $10 \mathrm{UFC} / \mathrm{mL}$; (B) Staphylococcus aureus ATCC25923/Colunas: PM) peso molecular 100 pares de base (Invitrogen® Thermo Fisher Scientific); 1) controle negativo mix; 2) amostra $10^{5} \mathrm{UFC} / \mathrm{mL}$; 3) amostra $10^{4} \mathrm{UFC} / \mathrm{mL}$; 4) amostra $10^{3} \mathrm{UFC} / \mathrm{mL}$; 5) amostra $10^{2} \mathrm{UFC} / \mathrm{mL}$; 6) amostra $10 \mathrm{UFC} / \mathrm{mL}$ 28

Figura 5 - Celularidade liquórica de 43 pacientes submetidos à neurocirurgia e com probabilidade de diagnóstico de meningite bacteriana 31

Figura 6 - Proteinorraquia de 43 pacientes submetidos à neurocirurgia e com probabilidade de diagnóstico de meningite bacteriana 31

Figura 7 - Lactatorraquia de 43 submetidos à neurocirurgia e com probabilidade de diagnóstico de meningite bacteriana 32

Figura 8 - Glicorraquia de 43 pacientes submetidos à neurocirurgia e com probabilidade de diagnóstico de meningite bacteriana 32 
Figura 9 - Fluxograma demonstrando o direcionamento das amostras de acordo com 0 paciente, a cultura microbiológica e resultado da reação em cadeia da polimerase (PCR) para o gene 16S RNA ribossomal 
Medeiros M. Padronização de teste molecular para o diagnóstico de meningites bacterianas pós-neurocirurgia [tese]. São Paulo: Faculdade de Medicina, Universidade de São Paulo; 2018.

Resumo: A meningite é uma inflamação das membranas que revestem o sistema nervoso central. As principais etiologias desta doença são de origem infecciosa, podendo ser bacteriana, fúngica ou viral. A meningite pode ocorrer como uma infecção hospitalar e pode ser associada a trauma ou neurocirurgia. Quando diagnosticada após um procedimento neurocirúrgico, a maior parte dos agentes infecciosos causadores da meningite provem da microbiota endógena da pele e do cabelo. No entanto, existem casos no qual o agente etiológico não é diagnosticado pelas técnicas laboratoriais convencionais, como a cultura microbiológica e bacterioscopia, dificultando a prescrição de terapias adequadas. O objetivo deste estudo foi identificar os agentes causadores de meningite após neurocirurgia (MAN) utilizando técnicas de biologia molecular e comparando-as com a cultura microbiológica. Foram incluídas amostras de líquido cefalorraquidiano (LCR) de pacientes submetidos a neurocirurgia e pacientes submetidos a cirurgias eletivas com uso de raquianestesia durante 0 período de 2015 a 2016. A reação em cadeia da polimerase (PCR) foi utilizada para avaliação da presença do gene $16 \mathrm{~S}$ do DNA ribossômico, comum em microrganismos de origem bacteriana, e o sequenciamento do mesmo para a identificação do agente etiológico. As amostras foram classificadas em 5 grupos de acordo com a suspeita clínica e dados quimiocitológicos do LCR: meningite bacteriana (MB) confirmada, MB possível, MB provável, MB improvável e sem $\mathrm{MB}$, neste último grupo estão apenas pacientes submetidos a cirurgias eletivas. Das 51 amostras de LCR incluídas (43 pós-neurocirurgia e 8 pré-anestésica), 21 $(41,2 \%)$ apresentaram cultura microbiológica negativa com PCR positiva, sendo: $3(14,2 \%)$ MB possível, 4 (19,0\%) MB provável, 13 (62,0\%) MB improvável, 1 $(4,8 \%)$ sem MB. Do total de 15 amostras positivas para PCR foi identificada ao menos a família filogenética, houve predomínio de microrganismos Gram negativos, somando 11 contra 4 Gram positivos. A identificação dos agentes etiológicos na MAN, incluindo os não detectados por métodos convencionais de identificação laboratorial, demonstraram que a biologia molecular pode complementar o diagnóstico colaborando de forma positiva, guiando 0 tratamento para o microrganismo específico ou sua família.

Descritores: meningite; infecção; craniotomia; líquido cefalorraquidiano; diagnóstico; DNA Ribossômico 16S; análise de sequência 
Medeiros M. Standardization of molecular test for the diagnosis of bacterial meningitis after neurosurgery [thesis]. São Paulo: "Faculdade de Medicina, Universidade de São Paulo"; 2018.

Abstract: Meningitis is an inflammation of the membranes covering the central nervous system. The main causes of this disease are bacterial, fungal or viral agents. Meningitis may be associated with trauma or neurosurgery. When meningitis is diagnosed after a neurosurgical procedure, the most common microorganisms belong to skin and hair microbiota. However, there are cases in which the etiological agent is not diagnosed by conventional laboratory techniques, such as microbial culture and bacterioscopy, which makes it difficult to establish adequate therapies. The objective of this study is to identify agents causing meningitis after neurosurgery (MAN) using polymerase chain reaction (PCR) and sequencing of the 16S rRNA gene, compared to the conventional microbiological culture. Cerebrospinal fluid (CSF) was collected from 43 patients who had undergone neurosurgery and 8 patients during spinal anesthesia were included during the period from 2015 to 2016 . Polymerase chain reaction (PCR) was used to evaluate the presence of the 16S ribosomal RNA gene, common in microorganisms of bacterial origin, and the sequencing of the same for the identification of the etiological agent. Samples were classified into five groups according to clinical data and CSF analysis: confirmed bacterial meningitis (MB), probable MB, possible MB, unlikely MB, no meningitis, in this last group are only patients submitted to elective surgeries. There were $51 \mathrm{CSF}$ samples included (43 post neurosurgery and 8 pre-spinal anesthesia), 21 samples (41.2\%) presented negative microbial culture and were PCR-positive, divided as: 3 (14.2\%) probable MB, $4(19 \%)$ possible MB, $13(62 \%)$ unlikely MB and $1(4.8 \%)$ no meningitis. From the total of 15 PCR-positive samples at least the phylogenetic family was identified with a predominance of Gram negative microorganisms, (11). The identification of etiologic agents in MAN, including those not detected by conventional laboratory identification methods, suggests molecular biology can complement the diagnosis and collaborate in guiding the treatment for the specific microorganism or its family.

Descriptors: meningitis; infection; craniotomy; cerebrospinal fluid; diagnosis; RNA, Ribosomal, 16S; sequence analysis. 


\section{INTRODUÇÃO}

As meninges são as três membranas que revestem o encéfalo e medula espinhal no qual, por sua vez constituem o sistema nervoso central (SNC). A dura-máter (mais externa), a aracnóide (intermediária) e a pia-máter (mais interna) possuem a função de proteção. Entre a camada aracnóide e pia-máter existe o espaço sub-aracnóide onde o líquor ou líquido cefalorraquidiano (LCR) circula, protegendo mecanicamente o SNC. (Mandell et al., 2010; Veronesi; Focaccia, 2010; Heth 2012; Tortora; Funke; Case, 2012).

A meningite é o processo inflamatório das membranas que revestem o SNC. O comprometimento infeccioso destas meninges pode ser classificado em três categorias: agudo, subagudo ou crônico, dependendo da velocidade da apresentação inicial e da taxa de progressão da doença (Levinson, 2016).

\subsection{MENINGITE AGUDA}

A meningite aguda se refere a uma síndrome caracterizada pelo aparecimento de febre, dor de cabeça, correlacionados à pleocitose do LCR devido à infecção e inflamação no espaço sub-aracnóide. Normalmente este tipo de infecção se desenvolve rapidamente, ao longo de horas até alguns dias, e tem como agentes causadores bactérias e vírus (Davis, 2006; Roos, 2006; Mandell et al., 2010). A meningite aguda pode ser distribuída em sub-categorias como na tabela 1.

\subsubsection{Meningite viral aguda}

As meningites virais são tipos mais comuns de meningite encontrados na clínica médica. Os agentes mais frequentes são: enterovírus (coxsackievirus A e $\mathrm{B}$, echovirus), vírus Epstein-Barr, varicela-zoster vírus, herpes vírus do tipo 2 (HSV-2), vírus HIV do tipo 1 (HIV-1), e arbovírus (Roos, 2006; Codina et al., 2011; Mandell et al., 2010). Ocasionalmente alguns vírus como da coriomeningite linfocitária, vírus da caxumba e adenovírus também podem causar meningite (Roos, 2006). 
Algumas meningites agudas são denominadas assépticas, devido à ausência de etiologia viral, fúngica ou bacteriana identificável (Connolly; Hammer, 1990; Riddell; Shuman 2012). Geralmente têm evolução benigna com exceção de Herpes simplex, noqual podem ocorrer complicações neurológicas como o desenvolvimento de encefalite herpética (Codina et al., 2011; Mandell et al., 2010). 
Tabela 1 - Classificação da meningite aguda de acordo com o tipo de agente infeccioso, faixa etária do paciente e microrganismos associados

\begin{tabular}{|c|c|c|c|}
\hline Classificação & Agente & Faixa etária & Microrganismos \\
\hline \multirow{21}{*}{ Aguda } & \multirow{8}{*}{ Viral } & \multirow{8}{*}{ Todas as idades } & Enterovírus \\
\hline & & & Vírus coxsackie A e B \\
\hline & & & Echovírus \\
\hline & & & Arbovírus \\
\hline & & & Vírus herpes simplex tipo 2 \\
\hline & & & Vírus Epstein- Barr \\
\hline & & & Vírus do HIV tipo 1 \\
\hline & & & Vírus varicella-zoster \\
\hline & \multirow{10}{*}{$\begin{array}{l}\text { Bacteriana } \\
\text { comunitária }\end{array}$} & $\begin{array}{l}\text { Neonatos } \\
(0-30 \text { dias })\end{array}$ & $\begin{array}{c}\text { Streptococcus agalactiae } \\
\text { Escherichia coli } \\
\text { Listeria monocytogenes }\end{array}$ \\
\hline & & & Streptococcus agalactiae \\
\hline & & $\begin{array}{c}\text { Bebês } \\
(1-23 \text { meses })\end{array}$ & $\begin{array}{c}\text { Streptococcus pneumoniae } \\
\text { Neisseria meningitidis } \\
\text { Haemophilus influenzae } \\
\text { Escherichia coli }\end{array}$ \\
\hline & & $\begin{array}{c}\text { Crianças e adolescentes } \\
\qquad(2-18 \text { anos })\end{array}$ & $\begin{array}{c}\text { Streptococcus pneumoniae } \\
\text { Neisseria meningitidis }\end{array}$ \\
\hline & & Adultos & Streptococcus pneumoniae \\
\hline & & (18 - 65 anos) & Neisseria meningitidis \\
\hline & & & Streptococcus pneumoniae \\
\hline & & Idosos & Escherichia coli \\
\hline & & (a partir de 65 anos) & Listeria monocytogenes \\
\hline & & & Enterobactérias \\
\hline & \multirow{3}{*}{$\begin{array}{l}\text { Bacteriana } \\
\text { Hospitalar }\end{array}$} & & Streptococcus pneumoniae \\
\hline & & Imunocomprometidos & $\begin{array}{l}\text { Neisseria meningitidis } \\
\text { Listeria monocytogenes } \\
\text { Bacilos gram-negativos }\end{array}$ \\
\hline & & $\begin{array}{l}\text { Pós-trauma ou } \\
\text { pós-cirúrgico }\end{array}$ & $\begin{array}{c}\text { Staphylococcus aureus } \\
\text { Staphylococcus epidermidis } \\
\text { Bacilos gram-negativos }\end{array}$ \\
\hline
\end{tabular}

FONTE: Tabela adaptada do trabalho publicado por Mandell et al., 2010 e Tacon; Flower, 2012 


\subsubsection{Meningite bacteriana aguda adquirida na comunidade}

A meningite bacteriana aguda comunitária é considerada uma emergência médica, e quando não tratada a mortalidade pode chegar a 100\% dos casos. Esta doença pode ser causada por diferentes microrganismos de acordo com a faixa etária ou situação no qual o indivíduo se encontra (Tabela1) (Tacon; Flower, 2012), mas principalmente por Streptococcus pneumoniae e Neisseria meningitidis.

A prevalência de cada bactéria está relacionada com um ou mais dentre os seguintes fatores: i) idade do paciente; ii) porta de entrada ou foco séptico inicial; iii) tipo e localização da infecção no SNC; iv) estado imunitário prévio específico geral; v) situação epidemiológica local (comunidade) (Veronesi; Focaccia, 2010).

\subsubsection{Meningite bacteriana aguda hospitalar}

A meningite bacteriana aguda também pode ser adquirida durante a prestação de assistência a saúde dentro de um hospital, sendo normalmente associada a uma variedade de procedimentos invasivos ou a traumatismos cranianos. É também denominada meningite nosocomial devido aos prováveis agentes etiológicos que estão circulando no ambiente hospitalar (Tunkel et al., 2017).

A meningite após neurocirurgia (MAN) é definida como infecção das meninges adquirida no prazo de até três meses após um procedimento neurocirúrgico (Chang et al., 2010). Os sintomas são semelhantes aos da meningite comunitária: dor de cabeça, febre, náusea e redução do nível de consciência. Mas, estes pacientes também podem apresentar febre por razões que não estão relacionadas à infecção (por exemplo, febre pelo uso de medicamentos, tromboflebite ou meningite química após a cirurgia da fossa posterior). Estes pacientes submetidos a neurocirurgia tem uma probabilidade maior de desenvolvimento de infecção devido ao risco associado a própria cirurgia, em razão da exposição direta do sistema nervoso central ao meio 
externo, e o aumento do risco de meningite em pacientes com fístula liquórica (Tunkel et al., 2017).

A meningite bacteriana é uma complicação pós-operatória temida devido às consequências prejudiciais aos pacientes como: sequelas, aquisição de novas infecções, reabordagem cirúrgica, prolongamento do tempo de internação e óbito (Vichi, 2004; Wang et al., 2005; Favaro et al., 2013).

Os procedimentos cirúrgicos mais frequentemente relacionados com MAN são: craniotomia para tratamento de lesão no crânio, tumor cerebral ou hemorragia intracraniana, colocação de dispositivo ventricular externo (DVE), implantação de derivação ventrículo-peritoneal (DVP) e ventriculostomia (Chang et al., 2008; 2010; Dabrowski et al., 2017).

\subsubsection{Agentes etiológicos encontrados na MAN}

Os agentes etiológicos mais comuns na MAN são dependentes da microbiota hospitalar e também estão relacionados aos fatores de pré-disposição à infecção após neurocirurgia. Os microrganismos frequentemente identificados são: Staphylococcus aureus, seguida dos bacilos gram-negativos e Staphylococcus coagulase negativa (SCN) os quais são encontrados principalmente após procedimento neurocirúrgico ou hospitalização prolongada após trauma penetrante. Já no caso de fratura na base do crânio os agentes etiológicos estão ligados a microbiota da nasofaringe como Streptococcus pneumoniae, Haemophilus influenzae, Streptococcus $\beta$-hemolítico do grupo A. Quando há presença de um corpo estranho, como a colocação de derivações externas pós-craniotomias, foi observada a frequência de microrganismos provenientes da microbiota da pele, tais como Propionibacterium acnes e os SCN como Staphylococcus epidermidis. (Tunkel et al., 2004; McClelland, 2008; Codina et al., 2011; Van de Beek; Drake; Tunkel, 2010; Figueiredo; Balasso, Teixeira, 2012) 
Tabela 2 - Principais agentes etiológicos relacionados aos fatores de predisposição a infecção após neurocirurgia

\begin{tabular}{ll}
\hline Fator de predisposição & Agentes etiológicos \\
\hline Trauma penetrante & $\begin{array}{l}\text { Staphylococcus aureus } \\
\text { Staphylococcus coagulase negativa } \\
\text { Bacilos Gram-negativos }\end{array}$ \\
\hline Pós-operatório de neurocirurgia & $\begin{array}{l}\text { Staphylococcus aureus } \\
\text { Bacilos Gram-negativos }\end{array}$ \\
\hline \multirow{3}{*}{ Fratura na base do crânio } & $\begin{array}{l}\text { Streptococcus pneumoniae } \\
\text { Haemophilus influenzae } \\
\text { Streptococcus } \beta \text {-hemolítico do grupo A }\end{array}$ \\
\hline Derivação ventricular & $\begin{array}{l}\text { Staphylococcus coagulase negativa } \\
\text { Staphylococcus aureus } \\
\text { Propionibacterium acnes } \\
\text { Bacilos Gram-negativos }\end{array}$ \\
\hline
\end{tabular}

\subsubsection{Epidemiologia da MAN}

A MAN é uma complicação grave e que representa um perigo para o paciente neurocirúrgico, necessitando intervenção médica ou cirúrgica imediatamente após a suspeita (McClelland, 2008; Simon et al., 2014).

Como procedimento padrão antes de uma neurocirurgia é dado ao paciente uma profilaxia com antimicrobianos que tem a capacidade de ultrapassar a barreira hemato-encefálica. $O$ uso generalizado de antimicrobianos para infecções do trato respiratório superior e a frequência de procedimentos neurocirúrgicos podem ter mudado esta epidemiologia aumentando o número de casos de MAN (Wang et al., 2005).

A maioria dos estudos sobre MAN desenvolvidos fora do Brasil são pesquisas retrospectivas associadas a outras infecções do sistema nervoso central, como abscessos, e que apenas demonstram a prevalência de determinados microrganismos nesses tipos de infecção. (Wang et al., 2005; Kallel et al., 2006; Kelly et al., 2006; McClelland, 2008; O'Brien et al., 2011; Howitz; Homøe, 2013) 
No Brasil apenas dois estudos foram publicados nos últimos anos: um estudo de revisão foi publicado por Figueiredo e colaboradores em 2012 demonstrando as principais infecções do SNC pós-procedimento da craniotomia, revisando dados epidemiológicos, profilaxia e fatores de risco. Mas este estudo não avalia mais a fundo os microrganismos encontrados na MAN. Já o segundo estudo foi conduzido por Camacho e colaboradores em 2013 no qual investigou o impacto de uma intervenção educacional implantada em uma unidade de tratamento neurológico intensivo, demonstrando as taxas de infecção relacionadas a colocação de DVE.

\subsection{DIAGNÓSTICO}

Para o diagnóstico da meningite é fundamental a análise do LCR. Para isso é necessário fazer a coleta do LCR através de punção lombar ou através de sistemas de derivação externa ou interna. A punção lombar é uma técnica invasiva e pode ter riscos e consequências graves para os pacientes como dor de cabeça, dor ou desconforto na região lombar após o procedimento, infecção ou sangramento (Chanteau et al., 2007).

A apresentação clínica destes pacientes geralmente consiste de febre e meningismo, acompanhado ou não da redução do nível de consciência. Fenômenos inflamatórios originados por certos tipos de tumores, durante a manipulação dos tecidos, restos de reabsorção óssea ou sanguínea podem ser responsáveis por um diagnóstico similar. O LCR apresenta alterações semelhantes à infecção, mas estas podem ser devido à inflamação sem infecção (Ramos-Martínez et al., 2009).

\subsubsection{Diagnóstico convencional}

Uma vez no laboratório o LCR tem prioridade sendo processado imediatamente à sua chegada. Sempre que possível, o LCR deve ser obtido antes do estabelecimento do tratamento antimicrobiano para evitar a redução de sensibilidade e negativação de culturas para microrganismos (Codina et al., 2011). 
O diagnóstico de meningites associa a sintomatologia clínica clássica com resultados laboratoriais bioquímicos, citológicos e microbiológicos do LCR (Saravolatz et al., 2003; Figueiredo; Balasso, Teixeira, 2012). Após a coleta, este material é enviado para análise microbiológica convencional no qual é feito uma lâmina com a coloração de Gram e cultivo em meios aeróbico e anaeróbico.

Além deste exame também é analisado o perfil bioquímico e citológico do LCR em questão. Todos estes exames são liberados entre 24 e 48 horas após a solicitação (Saravolatz et al., 2003).

De acordo com protocolos dos Centers for Disease Control and Prevention/The National Healthcare Safety Network (CDC/NHSM) de 2015, existem critérios epidemiológicos específicos para o diagnóstico de meningite. Para diagnosticar meningite é necessário atender, no mínimo, um dos seguintes critérios:

- Paciente deve ter cultura positiva a partir do LCR.

- Paciente deve apresentar pelo menos um dos seguintes sinais ou sintomas: febre maior que $37.8^{\circ} \mathrm{C}$, dores de cabeça, rigidez do pescoço, sinais meníngeos (sinais de Brudzinski, Kernig, Lasègue ou tripé), alterações dos nervos cranianos ou irritabilidade.

E pelo menos uma das seguintes opções:

- Alterações no LCR como: aumento de leucócitos, aumento de proteína e diminuição da glicose no LCR;

- Visualização dos microrganismos na coloração de Gram;

- Microrganismos cultivados a partir do sangue;

- Teste de antígeno positivo do líquor, sangue ou urina;

- Aumento de títulos de anticorpos: único título (IgM) ou 4 vezes a titulação em soros pareados (lgG) para patógenos específicos;

- Ser diagnosticado por médico assistente e ter prescrição de antibiótico para o tratamento.

Para definir qual a etiologia da meningite o resultado do exame liquórico diferencial é de grande importância para direcionar o diagnóstico. Com este resultado é possível determinar a intensidade do processo inflamatório, anticorpos específicos e além de informar indiretamente o agente infeccioso (Veronesi; Focaccia, 2010). Portanto o diagnóstico precoce e o tratamento 
adequado do paciente com meningite bacteriana são fundamentais e decisivos para a cura (Saravolatz et al., 2003, Heth 2012, Tacon; Flower, 2012).

Muitas vezes a cultura tem resultado negativo devido a sensibilidade do método ou pelo envolvimento de bactérias e fungos que são de difícil cultivo, já que exigem um tempo maior de crescimento e de alguns substratos que não são encontrados na rotina laboratorial. Além disso, pode haver um julgamento subjetivo para a identificação dos agentes infecciosos (Drancourt et al., 2000; Simon et al., 2014) como por exemplo Propionibacterium acnes e Mycobacterium sp. atípicas e do complexo tuberculoso.

\subsubsection{Tratamento}

Para um tratamento adequado é essencial uma correta identificação do agente etiológico. A partir disto a terapia é direcionada para o microrganismo em questão (Dabrowski et al., 2017).

Quando se trata de meningite bacteriana o tratamento deve ser administrado o mais brevemente possível. A antibioticoterapia, quando empírica, deve ser de amplo espectro e em altas concentrações, pois, o quadro pode evoluir rapidamente levando a complicações e sequelas neurológicas permanentes como, por exemplo, perda auditiva, retardo mental, convulsões e alterações comportamentais em até metade dos sobreviventes (Saravolatz et al., 2003).

Por outro lado, estas MAN podem ser difíceis de diagnosticar devido a mudanças muitas vezes sutis nos parâmetros do LCR, dificultando a visualização destas anormalidades que podem estar relacionadas à infecção, à colocação de dispositivos ou ainda à neurocirurgia (Tunkel et al., 2017).

\subsubsection{Diagnóstico complementar}

Em alguns casos o diagnóstico de meningite somente é possível após a realização de alguns exames complementares como: ressonância magnética, tomografia computadorizada, estudo de anticorpos e também através da identificação por biologia molecular (Mandell et al., 2010; Tunkel et al., 2017). 
A biologia molecular tem mostrado uma aplicabilidade generalizada para situações em que um diagnóstico rápido e preciso é necessário ou em que patógenos são de difícil cultivo utilizando os métodos tradicionais (Yang; Rothman, 2004; Banks et al., 2005; Favaro et al., 2013). No entanto, a biologia molecular está mais voltada para a identificação de agentes causadores de meningite bacteriana adquirida na comunidade e pouco tem-se estudado $o$ diagnóstico de meningite como manifestação de infecção de sítio cirúrgico.

Quando utilizada, a identificação molecular pode ocorrer através das tecnologias:

\subsubsection{Reação em Cadeia da Polimerase (PCR)}

A PCR é a amplificação específica e exponencial de uma região prédeterminada do ácido nucleico através de iniciadores denominados primers, que tem a função de delimitar a sequência de DNA alvo da amplificação (Yang; Rothman, 2004; van Pelt-Verkuil et al., 2008). Esta reação "in vitro" também utiliza uma enzima polimerase termoestável que sintetiza milhões de cópias de ácido nucleico alvo, gerando um produto denominado amplicon através de um

processo térmico e cíclico. O principal objetivo da PCR é amplificar a região do ácido nucleico de interesse até um limite detectável (Das; Shibib; Vernon, 2017).

Em casos de meningite a identificação molecular geralmente é aplicada na rotina laboratorial confirmando o agente etiológico da meningite tanto por bactérias, fungos e vírus. (Banks et al., 2005; Chanteau et al., 2006; 2007; Riddell; Shuman 2012). A PCR é uma ferramenta fundamental para otimizar a vigilância microbiológica em grande escala nos casos de surto de meningite comunitária (Chanteau et al., 2006; 2007).

Portanto, muitos especialistas consideram que a PCR ou a cultura microbiológica podem ser "padrões ouro" aceitáveis, reconhecendo que em contextos de recursos limitados (meios de cultura, provas bioquímicas, discos de antimicrobianos), a avaliação microbiológica definitiva não é viável (Robbins; Schneerson; Gotschlich, 2005; Chanteau et al., 2007; Rose et al., 2010; Won et al., 2012). 


\subsubsection{Reação em Cadeia da Polimerase em Tempo Real (RT-PCR)}

É uma análise "in vitro" dos produtos de amplificação por PCR feitas em tempo real no qual as sequências de DNA de interesse são marcadas com corantes fluorescentes e/ou sondas, e quantificadas através de espectroscopia de fluorescência. A presença ou ausência da sequência de DNA em questão é determinada por meio de curvas de amplificação para cada amostra (van PeltVerkuil; van Belkum; Hays, 2008).

A PCR em tempo real é uma metodologia mais rápida que a PCR convencional, pois a amplificação e a detecção ocorrem em um mesmo tubo diminuindo também o risco de contaminação do material amplificado (Espy et al., 2006), além de eliminar uma etapa necessária pós-PCR que é a eletroforese em gel para a detecção do produto da PCR (Yang; Rothman, 2004). Possui alta sensibilidade já que é um método quantitativo que detecta, em certas circunstâncias, o mínimo de duas cópias do DNA pré-selecionado na amostra. Possui também reprodutibilidade e informa um resultado rápido e confiável que é fundamental no diagnóstico de meningites (Favaro et al., 2013).

Em rotina laboratorial, a PCR em tempo real foi incluída principalmente na identificação de vírus e alguns tipos de bactérias em materiais clínicos como por exemplo: vírus herpes simplex (HSV), vírus da varicella zoster (VZV), vírus herpes humano do tipo 6 (HHV-6), HHV-7, HHV-8, citomegalovírus (CMV), vírus Epstein-Barr (EBV), enterovírus (EV), adenovírus humano (HAdV) e parechovírus humano (HPeVs) (Parisi et al., 2016). No entanto há pouca descrição para microrganismos causadores de infecções relacionadas à assistência à saúde (IRAS).

\subsubsection{Sequenciamento genético}

É o método mais preciso para a análise da região amplificada pelo PCR. É frequentemente utilizada como um pós-PCR para acompanhamento de: (i) rastreamento de mutação; (ii) definir subtipos de bactérias ou genoma de vírus; (iii) elucidar a base molecular da doença; (iv) para a otimização e 
desenvolvimento de novas sequências iniciadoras de PCR (van Pelt-Verkuil; van Belkum; Hays, 2008).

Em 1977, Frederick Sanger desenvolveu uma tecnologia de sequenciamento de DNA baseado no método de terminação de cadeia (também conhecido como sequenciamento Sanger), Gilbert e Walter desenvolveram outra tecnologia de sequenciamento com base na modificação química de DNA e subsequente clivagem em bases específicas. Devido à sua baixa eficiência e alta radioatividade, o sequenciamento de Sanger foi adotado como a tecnologia primária na "primeira geração para aplicações de sequenciamento comerciais" (Liu et al., 2012).

E após sucessivas melhorias nos sistemas de automação, plataformas, softwares, metodologia de sequenciamento é possível afirmar que os sequenciadores modernos pertencentes à next generation sequencing (NGS) associam bom desempenho na produção, com precisão e custos menores (Liu et al., 2012).

\subsection{ESTUDO DO RNA RIBOSSOMAL PROCARIÓTICO}

Atualmente, as moléculas marcadoras de filogenenia mais úteis e investigadas são os RNA ribossômicos, especialmente 16S rRNAs e, em menor extensão, 23S rRNA (Ludwig; Schleifer 1994).

Os ribossomos nos microrganismos procarióticos possuem 2 subunidades: $50 \mathrm{~S}$ e $30 \mathrm{~S}$. A subunidade $50 \mathrm{~S}$ (subunidade maior) apresenta aproximadamente 34 proteínas, bem como os genes 5S RNA ribossomal (120 bases) e 23S RNA ribossomal (cerca de 2900 bases), e a subunidade 30S (subunidade menor) contém cerca de 20 proteínas e o gene 16S rRNA (cerca de 1500 bases) (Blaut et al., 2002).

Estudos moleculares demonstrados por Woese e colaboradores na década de 90 propõem que os todos os organismos vivos sejam classificados de acordo com a sequência do gene que codifica o RNA ribossomal. Esta nova taxonomia foi chamada "domínio", e esta divisão fica acima dos reinos classificados por Whittaker como: Animalia, Plantae, Fungi, Protista e Monera. Estes domínios foram nomeados como: Archaea, Bacteria e Eukarya (Woese; 
Kandler; Wheelis, 1990). A figura 1 abaixo mostra esta divisão proposta por Woese, em comparação com a subdivisão dos reinos proposta por Whittaker, que é a mais conhecida. Os reinos Animalia, Plantae, Fungi e Protista são classificados no domínio Eukarya, enquanto que o reino Monera se subdivide em dois domínios: Bacteria e Archaea.

\begin{tabular}{|c|c|c|c|}
\hline \multirow{7}{*}{ 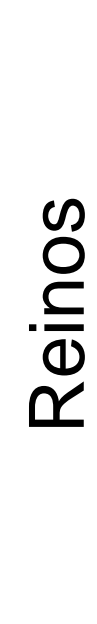 } & Whittaker 1969 & Woese 1990 & \multirow{7}{*}{$\begin{array}{l}\frac{0}{3} \\
\overline{\bar{\partial}} \\
\frac{\bar{D}}{0}\end{array}$} \\
\hline & Animalia & \multirow{4}{*}{ Eukarya } & \\
\hline & Plantae & & \\
\hline & & & \\
\hline & Protista & & \\
\hline & \multirow{2}{*}{ Monera } & Bacteria & \\
\hline & & Archaea & \\
\hline
\end{tabular}

FONTE: Woese, 1990 e Whittaker 1969

Figura 1 - Classificações taxonômicas propostas por Whittaker em 1969 e Woese em 1990

\subsubsection{Gene 16S DNA ribossomal}

Woese em 1987 relatou que o gene que codifica 16S rRNA bacteriano contém áreas altamente conservadas na sua sequência de nucleotídeos, e estas áreas estão intercaladas por porções hipervariáveis denominadas regiões "V" (Figura 2). A configuração destas sequências de regiões conservadas, variáveis e hipervariáveis são específicas para determinado grupo, ou grupos de organismos, permitindo a classificação filogenética e a identificação bacteriana (Ludwig; Schleifer, 1994; Blaut et al., 2002; Tannock, 2002; Yarza et al., 2014).

Atualmente o gene RNA ribossomal $16 \mathrm{~S}$ se tornou o maior marcador de sequências taxonômicas para a classificação sistemática de bactérias (Yarza et al., 2014). Através das técnicas moleculares é possível fazer o estudo de genes conservados pertencentes a todos os filos, incluindo bactérias de difícil cultivo ou não cultiváveis (Baker; Smith; Cowan, 2003). Portanto este gene tem sido 
pesquisado na microbiologia clínica como marcador de infecção nos mais diferentes materiais clínicos

Desta maneira, estudos que visem desenvolver métodos moleculares eficazes no diagnóstico de MAN são relevantes, pois não há estudos robustos atuais sobre este assunto. A identificação precisa destes microrganismos envolvidos na meningite pós-neurocirurgia pode nos revelar futuramente dados importantes para a epidemiologia. Através destes resultados será possível verificar a frequência dos agentes causadores de MAN e assim direcionar esquemas de tratamento terapêutico racional e futuramente tomar precauções cabíveis para evitá-las. 


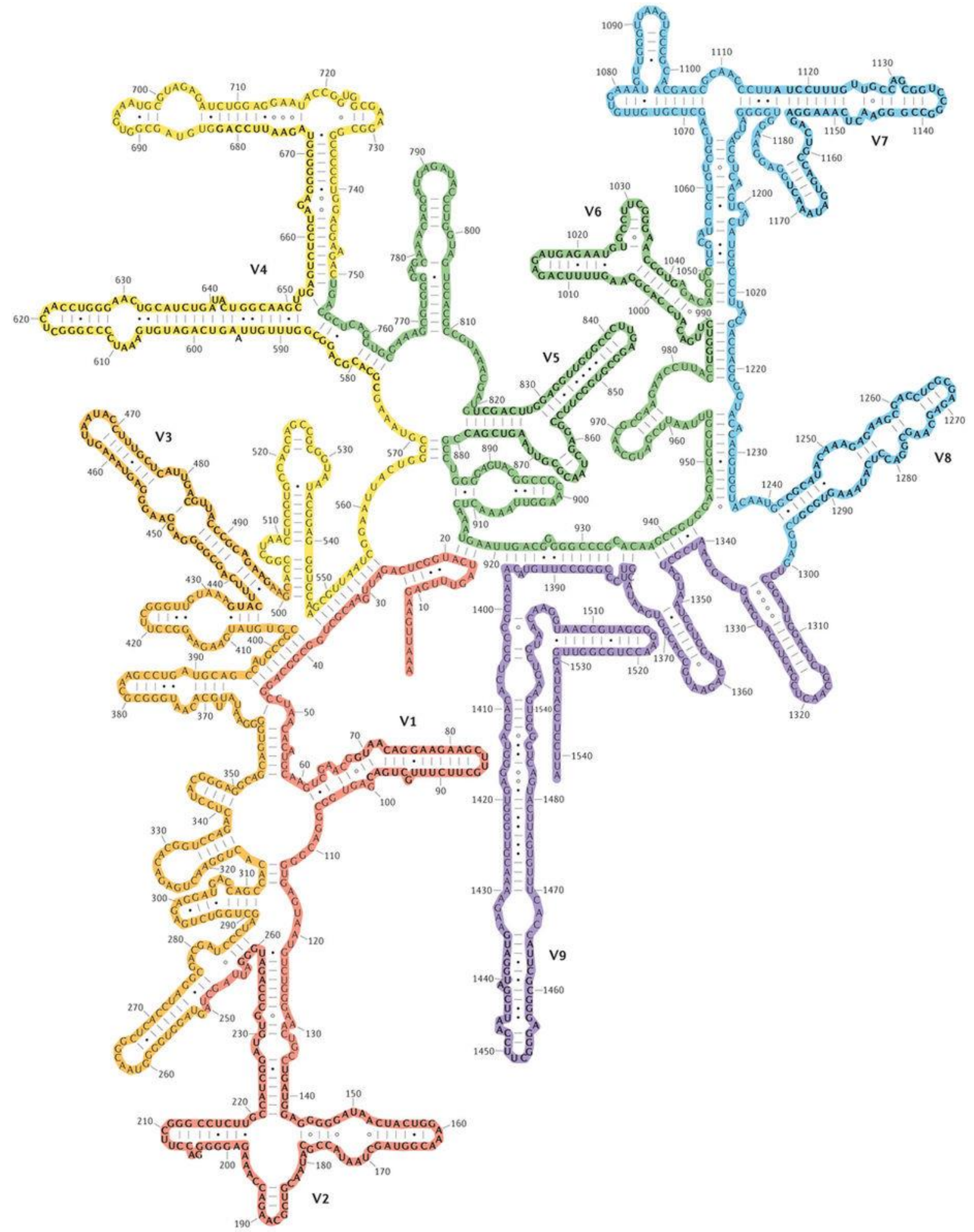

FONTE: Adaptado de Yarza et al., 2014

Figura 2 - Regiões variáveis do RNA ribossomal16S. Cada região variável no RNA ribossomal $16 S$ está representada por uma cor diferente. As regiões V1 e V2 está em cor vermelha; V3 em laranja; V4 em amarelo; V5 e V6 e verde; V7 e V8 em azul e V9 em roxo 


\section{OBJETIVOS}

- Desenvolver um método de biologia molecular capaz de diagnosticar meningites pós-neurocirurgia.

- Comparar o desempenho de biologia molecular com cultura microbiológica convencional. 


\section{MATERIAL E MÉTODOS}

\subsection{LOCAL DO ESTUDO}

O estudo foi desenvolvido no Hospital das Clínicas da Faculdade de Medicina da Universidade de São Paulo (HCFMUSP). O HCFMUSP é um hospital público, terciário e universitário, conveniado ao Sistema Único de Saúde, constituído principalmente por seis institutos especializados e dois hospitais auxiliares, que somam cerca de 2.200 leitos.

O armazenamento das amostras de LCR, a estocagem dos microrganismos utilizados e os experimentos de padronização e aplicação da técnica em questão foram realizados no Laboratório de Investigação Médica 54 - LIM54.

Ainda para este estudo, foram envolvidos pacientes internados em unidades de dois institutos: o Instituto Central do Hospital das Clínicas (ICHC) e o Instituto de Psiquiatria (IPq). O ICHC dispõe de 24 enfermarias clínicas, 12 enfermarias cirúrgicas e 12 Unidades de Terapia Intensiva (UTI), abrangendo um total de 987 leitos. Por sua vez, o IPq tem 205 leitos distribuídos em enfermarias (201 leitos, dos quais 18 são neurocirúrgicos) e uma UTI (4 leitos). No IPq são realizadas cerca de 400 craniotomias por ano. Dessa forma, os pacientes envolvidos nesse estudo tiveram suas cirurgias realizadas nos Centros Cirúrgicos do ICHC ou no IPq.

\subsection{DESENHO DO ESTUDO}

Inicialmente, foi realizada a padronização do teste de biologia molecular em amostras de LCR de pacientes sabidamente sem meningite. Pela necessidade de grande volume de LCR para a determinação dos limites de detecção do kit de extração e purificação, foram selecionados dois pacientes que necessitavam realizar o Tap Test, já que tal procedimento permite a retirada de grande volume de LCR. Depois dessa etapa concluída, foi realizada então a aplicação do método em LCR de pacientes internados. 
Sistematicamente, os pacientes internados com suspeita de meningite pós-neurocirurgia têm amostras de LCR coletadas e enviadas para 0 Departamento de Laboratório Central (DLC) do Hospital das Clínicas. A coleta é feita em 3 frascos diferentes, contendo $2 \mathrm{~mL}$ cada, e enviados para as avaliações citológica, bioquímica e microbiológica. Nestas avaliações são determinados os perfis citológico e bioquímico e também são realizados os testes para identificação presuntiva e confirmatória do agente etiológico (bacterioscopia com coloração de Gram, cultura em meios semissólidos, identificação pelo Vitek MS® ou testes fenotípicos manuais e antibiograma automatizado por Vitek $2 \circledast$ ou manual por disco difusão ou por E-test $\AA$ ). Os resultados dos estudos quimiocitológicos e microbiológicos foram utilizados para categorizar os pacientes com relação à probabilidade do diagnóstico de meningite. Para a realização deste estudo, um quarto frasco foi coletado e encaminhado ao Laboratório de Investigação Médica 54 (LIM54), onde foram realizadas as etapas de extração, purificação e PCR, bem como suas etapas subsequentes, para o sequenciamento do gene $16 \mathrm{~S}$ rRNA.

Para a comparação entre os testes de diagnóstico etiológico (cultura e PCR), foram resgatados os resultados do Setor de Microbiologia da DLC e então correlacionados com os de biologia molecular realizado no LIM54.

Para comparação de resultados de pacientes com suspeita de meningite com pacientes sem suspeita de meningite, foram também envolvidos no estudo pacientes sem doenças do SNC, não expostos a neurocirurgia, submetidos a cirurgias eletivas que necessitassem de raquianestesia (para facilitar a coleta de LCR sem mais invasões do que suas programações terapêuticas exigissem). As amostras foram coletadas após termo de consentimento livre e esclarecido (TCLE) ser compreendido e assinado.

\subsection{PACIENTES}

Para a primeira etapa deste estudo foram incluídos dois pacientes adultos com hidrocefalia de pressão normal (HPN), acompanhados regularmente pelo ICHC, e que, quando necessário, são submetidos ao Tap Test. Estas 
amostras de LCR foram utilizadas para a validação dos limites de detecção do kit de extração e purificação de DNA.

Para a segunda etapa deste estudo, quando o método padronizado foi aplicado às amostras de pacientes submetidos à neurocirurgia, foram selecionados pacientes previamente submetidos à neurocirurgia limpa, com suspeita de meningite no pós-operatório, mas também pacientes sem doença do SNC submetidos à cirurgia eletiva com utilização de anestesia raquidiana (pacientes sem suspeita de meningite). Todos esses pacientes foram operados e acompanhados no próprio HCFMUSP (ICHC e IPq).

Cada paciente foi incluído apenas uma vez na pesquisa. No momento da inclusão do paciente no estudo, os seus dados foram coletados diretamente do prontuário médico e copiados para uma ficha clínica (anexo A). Durante a internação, foram coletados: sexo, idade, data e motivo da internação hospitalar, comorbidades, diagnóstico de infecções prévias, dados da neurocirurgia (se aplicável), data da suspeita de meningite (se aplicável), utilização de antimicrobianos e dados laboratoriais do LCR. Os dados dos pacientes foram pesquisados nos prontuários "online" disponíveis nos sistemas informatizados do hospital, à medida que os pacientes eram selecionados para a pesquisa.

Para eliminar qualquer falsa elevação na contagem diferencial de células brancas que podem ser causadas por: sangramento durante a coleta do LCR, ou em pacientes com hemorragias subaracnóideas ou intracraniais, foi feito um cálculo de correção utilizando a seguinte fórmula: descontar um leucócito na contagem de leucócitos para cada 1000 hemácias contadas no LCR (Seehusen; Reeves, Fomin 2003). 


\subsection{PADRONIZAÇÃO DO TESTE DE BIOLOGIA MOLECULAR PARA DIAGNÓSTICO DE MAN EM AMOSTRAS DE LCR INOCULADAS COM BACTÉRIAS}

\subsubsection{Validação da amplificação do gene 16S rRNA}

Antes da determinação dos limites de detecção do método aplicável a amostras de LCR, foi necessária a validação interna da reação no laboratório. Para tal, foram submetidas a PCR para o gene 16S rRNA: controle negativo (apenas os reagentes utilizados na reação, sem DNA), amostras de LCR com cultura bacteriana negativa, amostras de LCR com cultura bacteriana positiva (pacientes com meningite confirmada) e DNA obtido a partir de cultura bacteriana pura.

A amplificação do gene 16S rRNA foi feita por PCR com a utilização dos primers 331F e 797R (regiões V3 e V4 do gene 16S RNA ribossomal) (Nadkarni, et al., 2002; Deutch et al., 2007) (Tabela 3). Na reação foi utilizada HotStarTaq ${ }^{\circledR}$ DNA Polymerase (Qiagen ${ }^{\circledR}$ ) e, para a amplificação, foram utilizadas as seguintes parâmetros: 95ํㅡ por 10 minutos seguidos de 35 ciclos de desnaturação do DNA por 45 segundos a $95^{\circ} \mathrm{C}$, anelamento do DNA por 45 segundos com a variação de temperatura de $57^{\circ} \mathrm{C}$ e extensão do DNA por 2 minutos a $72^{\circ} \mathrm{C}$. Após 0 término dos ciclos, foi realizada uma etapa de estabilização do DNA por 10 minutos a $72^{\circ} \mathrm{C}$. Foram utilizadas como controle de reação positiva DNA extraído de cultura bacteriana e DNA extraído de LCR com cultura bacteriana positiva.

Tabela 3 - Sequência de nucleotídeos padronizados para a reação em cadeia da polimerase (PCR) do gene 16S rRNA

\begin{tabular}{llcc}
\hline $\begin{array}{l}\text { Identificação } \\
\text { do primer }\end{array}$ & Sequência de nucleotídeos & $\begin{array}{l}\text { Temperatura de } \\
\text { anelamento }\end{array}$ & $\begin{array}{l}\text { Tamanho do } \\
\text { amplicon }\end{array}$ \\
\hline $331 \mathrm{~F}$ & 16S rRNA- TCCTACGGGAGGCAGCAGT & $57^{\circ} \mathrm{C}$ & $\begin{array}{l}466 \text { pares de } \\
\text { bases }\end{array}$ \\
$797 \mathrm{R}$ & 16S rRNA- GGACTACCAGGGTATCTAATCCTGTT & & \\
\hline
\end{tabular}


A seguir, 8 microlitros $(\mu \mathrm{L})$ de cada produto da PCR juntamente com $1 \mu \mathrm{L}$ de BlueJuice ${ }^{\mathrm{TM}}$ Gel Loading Buffer (Invitrogen ${ }^{\circledR}$ Thermo Fisher Scientific) foram aplicados em gel de agarose a $1,5 \%$ e a eletroforese foi realizada a $120 \mathrm{~V}$ por uma hora e quinze minutos. Também foram aplicados no gel de agarose $4 \mu \mathrm{L}$ de peso molecular 100pb DNA Ladder ${ }^{\mathrm{TM}}$ (Invitrogen® Thermo Fisher Scientific) adicionados a $1 \mu \mathrm{L}$ BlueJuice ${ }^{\mathrm{TM}}$ Gel Loading Buffer (Invitrogen ${ }^{\circledR}$ Thermo Fisher Scientific). Os géis foram corados com SYBRSafe (Invitrogen $\AA$ Thermo Fisher Scientific) e visualizados em fotodocumentador, utilizando luz ultravioleta. Foi considerada reação positiva o achado de banda compatível com o controle positivo (466 pares de bases). As amostras positivas foram enviadas para sequenciamento por Sanger, com MegaBACE 1000 (ABI 3730 DNA Analyzer, Applied Biosystems, Alameda, CA).

\subsubsection{Preparo das suspensões de microrganismos}

Para a padronização do método diagnóstico de meningites bacterianas por técnicas moleculares, foi feito um ensaio piloto utilizando amostras de LCR de pacientes sem suspeita de meningite submetidos ao Tap Test, inoculadas com bactérias American Type Culture Collection (ATCC) em laboratório.

Neste experimento foram utilizadas duas amostras de LCR com cultura negativa de pacientes com HPN que necessitaram fazer o Tap Test, quando então há a retirada de grande volume de LCR (mais de $10 \mathrm{~mL}$ ), o que permitiu a realização dos testes necessários. As amostras bacterianas estocadas no banco de cepas do LIM54 foram repicadas em meios de cultura semissólidos ( $S$. aureus ATCC25923 em ágar sangue e E. coli ATCC25922 em ágar MacConkey) e incubadas para crescimento em estufa a $35^{\circ} \mathrm{C}$ por 18 horas.

Com o objetivo de determinar a sensibilidade analítica, inicialmente foi comparada a densidade ótica entre o tampão fosfato-salino (PBS) e o LCR. Como foi demonstrado que a diferença de densidade ótica entre LCR e PBS fora de apenas 0,03 , foi utilizado o próprio LCR para calibração. Uma alíquota de PBS e uma de LCR foram inoculadas com S. aureus ATCC25923 e outra alíquota de PBS e LCR com E. coli ATCC25922, até a obtenção da leitura da densidade ótica de $0,5 \mathrm{McF}$ arland (o que corresponde a $1,5 \times 10^{8}$ unidades formadoras de 
colônia por mililitro - UFC/mL) para cada amostra de PBS e LCR inoculadas com os microrganismos ATCC.

A partir das amostras de LCR e de PBS inoculadas com 1,5x $10^{8} \mathrm{UFC} / \mathrm{mL}$ de bactérias ATCC, foram então construídas diluições seriadas passando 100 $\mu \mathrm{L}$ da suspensão bacteriana mais concentrada para $900 \mu \mathrm{L}$ de LCR ou PBS (volume final $=1000 \mu \mathrm{L}$ ), as concentrações das diluições foram de aproximadamente $1,5 \times 10^{7} ; 1,5 \times 10^{6} ; 1,5 \times 10^{5} ; 1,5 \times 10^{4} ; 1,5 \times 10^{3} ; 1,5 \times 10^{2}$ e $1,5 \times 10$ $\mathrm{UFC} / \mathrm{mL}$ das cepas de $S$. aureus e E. coli. A partir destas diluições, $500 \mu \mathrm{L}$ de cada teste foram submetidos a extração de DNA pelo kit MagNA Pure Compact Nucleic Acid Isolation Kit I - Large $\AA$ (Roche Diagnostics GmbH, Alemanha), cuja utilização acontecera respeitando-se as orientações do fabricante.

\subsubsection{Extração e purificação de DNA, PCR para o gene 16S RNA ribossomal e eletroforese}

A extração e a purificação do DNA das amostras de LCR foram realizadas por automação com o equipamento MagNA Pure Compact Instrument $\Theta$ (Roche Diagnostics GmbH, Alemanha) e o kit MagNA Pure Compact Nucleic Acid Isolation Kit I - Large ${ }^{\circledR}$ (Roche Diagnostics GmbH, Alemanha).

O princípio utilizado pelo equipamento MagNA Pure $\Theta$ para o isolamento das moléculas de DNA e RNA das amostras de LCR é a utilização de partículas de vidro magnético, as beads magnéticas. Nos tubos com as amostras foram adicionados tampão de lise e proteinase K. Depois da incubação das amostras foram adicionadas as beads magnéticas em que os ácidos nucleicos se ligam. Após sucessivas lavagens, os restos celulares e impurezas presentes na amostra foram removidos, restando apenas o complexo beads-ácidos nucleicos. $\mathrm{Na}$ fase final da extração, uma solução para eluição foi adicionada e os ácidos nucleicos foram desprendidos das beads por diferença de osmolaridade e aquecimento. O protocolo utilizado para a extração de DNA/RNA do LCR foi o indicado pelo fabricante para fluidos corporais, utilizando o volume inicial para extração de $500 \mu \mathrm{L}$ e volume final de eluição de $100 \mu \mathrm{L}$. 
Após extração do DNA, a amplificação do gene 16S rRNA e a eletroforese foram realizadas conforme os parâmetros supracitados na etapa de validação da PCR e da eletroforese.

\subsubsection{Purificação das amostras e sequenciamento de Sanger}

As amostras de LCR positivas no PCR 16S rRNA foram preparadas para o sequenciamento de Sanger através da purificação de DNA a partir do produto do PCR, utilizando o kit comercial Illustra ${ }^{T M}$ GFX ${ }^{T M}$ PCR DNA and Gel Band PuriFication Kit (GE). A quantificação do DNA foi feita utilizando o Low DNA Mass Ladder (Invitrogen® Thermo Fisher Scientific). Foi considerada a concentração ideal de DNA para o sequenciamento $5 \mathrm{ng} / \mathrm{mL}$, por amostra.

Foram preparados dois tubos: um contendo a amostra purificada adicionada ao primer 331F forward e outra adicionada ao 767R reverse, primers estes utilizados na reação de PCR. O sequenciamento para a confirmação do gene 16S rRNA foi realizado no Centro de Pesquisa Sobre o Genoma Humano e Células Tronco, Instituto de Biologia da Universidade de São Paulo. Foi utilizado o equipamento MegaBACE 1000 (ABI 3730 DNA Analyzer, Applied Biosystems, Alameda, CA).

\subsubsection{Análise das amostras sequenciadas}

As sequências geradas foram tratadas pelo BioEdit, que alinhou forward e reverse das sequências. Foi selecionada a parte que possuía consenso entre eles e foram substituídas as bases de nucleotídeos duvidosos (nucleotídeos sem consenso trocados ao alinhá-los com a sequência forward). Logo após os ajustes, a sequência genética consenso foi pesquisada para identificação taxonômica e comparada ao banco de dados do National Center of Biotechnology Information (NCBI) utilizando como ferramenta para busca e alinhamento das sequências o Basic Local Alignment Search Tool (BLAST) www.ncbi.nlm.nhi.gov/blast/ (Liu et al., 2012).

Os algoritmos de busca foram mantidos na posição default para comparação com os dados das sequências geradas de 16S rRNA. 


\subsection{APLICAÇÃO DO MÉTODO DE BIOLOGIA MOLECULAR PARA DIAGNÓSTICO DE MAN EM LCR DE PACIENTES SUBMETIDOS A NEUROCIRURGIAS}

Uma vez que o método foi padronizado, este processo foi aplicado no LCR de pacientes internados no ICHC e no IPq. Para tal, foram captados 43 pacientes que passaram por neurocirurgia e outros 8 pacientes que necessitaram de cirurgia eletiva com o uso de anestesia raquidiana.

As amostras foram coletadas, transportadas e processadas de acordo com o fluxo referenciado anteriormente. As amostras provenientes da DLC (suspeitas de meningite) ou do Centro Cirúrgico (sem meningite) foram encaminhadas ao LIM-54 e armazenadas a $4^{\circ} \mathrm{C}$ por até uma semana, sendo então divididas em alíquotas de $500 \mu \mathrm{L}$ em tubos plásticos Eppendorf ${ }^{\circledR}$ de $1500 \mu \mathrm{L}$, previamente esterilizados e conservados em freezer a $-80^{\circ} \mathrm{C}$ para análises posteriores (Simon et al., 2014).

Com os resultados do perfil quimiocitológico, cultura microbiológica e de biologia molecular e de acordo com sintomas clínicos dos pacientes (suspeita clínica se febre, náuseas, meningismo associado ou não a redução do nível de consciência), as amostras foram divididas em cinco categorias (Quadro 1). A contagem dos leucócitos foi corrigida através da diminuição de 1 célula para cada 1000 hemácias/mL na amostra (Seehusen; Reeves; Fomin, 2003). 
Quadro 1- Classificação de amostras de líquido cefalorraquidiano (LCR) de pacientes com e sem suspeita de meningite bacteriana (MB).

\begin{tabular}{|c|c|c|}
\hline GRUPO & CLASSIFICAÇÃO & DEFINIÇÃO \\
\hline $\begin{array}{c}\text { Grupo } 1 \\
\text { (G1) }\end{array}$ & $\begin{array}{c}\text { Meningite bacteriana } \\
\text { confirmada }\end{array}$ & Cultura microbiológica positiva para LCR \\
\hline $\begin{array}{c}\text { Grupo } 2 \\
\text { (G2) }\end{array}$ & $\begin{array}{c}\text { Meningite bacteriana } \\
\text { provável }\end{array}$ & $\begin{array}{l}\text { Suspeita clínica + celularidade liquórica } \geq 500 \text { céls } / \mathrm{mm}^{3} \\
+ \text { diferencial com } \geq 50 \% \text { de neutrófilos }+ \text { cultura } \\
\text { microbiológica negativa para LCR }\end{array}$ \\
\hline \multirow{2}{*}{$\begin{array}{c}\text { Grupo } 3 \\
\text { (G3) }\end{array}$} & \multirow{2}{*}{$\begin{array}{c}\text { Meningite bacteriana } \\
\text { possível }\end{array}$} & $\begin{array}{l}\text { Suspeita clínica + celularidade liquórica } \geq 500 \\
\text { céls } / \mathrm{mm} 3+\text { diferencial com }<50 \% \text { de neutrófilos }+ \\
\text { cultura microbiológica negativa para LCR ou }\end{array}$ \\
\hline & & $\begin{array}{l}\text { Suspeita clínica + celularidade liquórica < } 500 \text { céls } / \mathrm{mm}^{3} \\
\text { em uso de antimicrobiano há mais de } 1 \text { dia + cultura } \\
\text { microbiológica negativa para LCR }\end{array}$ \\
\hline \multirow[b]{2}{*}{$\begin{array}{c}\text { Grupo } 4 \\
\text { (G4) }\end{array}$} & \multirow[b]{2}{*}{$\begin{array}{c}\text { Meningite bacteriana } \\
\text { improvável }\end{array}$} & Sem suspeita clínica + neurocirurgia prévia \\
\hline & & $\begin{array}{l}\text { Suspeita clínica + celularidade liquórica }<500 \\
\text { céls } / \mathrm{mm} 3 \text { sem uso de antimicrobiano }+ \text { cultura } \\
\text { microbiológica negativa para LCR }\end{array}$ \\
\hline $\begin{array}{c}\text { Grupo } 5 \\
\text { (G5) }\end{array}$ & Sem meningite & $\begin{array}{l}\text { Sem suspeita clínica (pacientes submetidos a outras } \\
\text { cirurgias eletivas com anestesia raquidiana), sem } \\
\text { histórico de neurocirurgia. }\end{array}$ \\
\hline
\end{tabular}

Os grupos de 1 a 4 incluem apenas pacientes que foram submetidos previamente à neurocirurgia, já o grupo 5 somente pacientes submetidos a cirurgia eletiva com uso de anestesia raquidiana. 


\subsection{ANÁLISE ESTATIISTICA}

Os resultados foram compilados em planilhas e gráficos. Os dados das fichas clínicas foram categorizados, codificados e registrados em planilha de dados no programa Microsoft ${ }^{\circledR}$ Excel, versão Office 2010.

Os parâmetros quimiocitológicos do LCR dos pacientes submetidos à neurocirurgia e que apresentaram PCR positiva foram comparados aos que apresentaram PCR negativa, utilizando o teste $t$ de Student. Foi considerada diferença estatisticamente significante se $p \leq 0,05$.

\subsection{QUESTÕES ÉTICAS}

O projeto foi aprovado pela Comissão de Ética para Análise de Projetos de Pesquisa (CAPPesq) do HCFMUSP, com número do parecer 657.493 (anexo B). Para cada paciente selecionado, foi aplicado o TCLE (anexo C), assinado pelo paciente consciente ou pelo familiar responsável, para que a retirada da amostra de LCR fosse realizada. A coleta do LCR foi autorizada pelo médico responsável e colhida ao mesmo tempo da amostra enviada para o laboratório para exames de rotina. 


\section{RESULTADOS}

\subsection{PADRONIZAÇÃO DO MÉTODO}

\subsubsection{Validação da amplificação do gene 16S rRNA}

A reação de amplificação do gene $16 \mathrm{~S}$ rRNA foi validada com a aplicação dos parâmetros e amostras utilizadas. $O$ controle negativo e amostras de pacientes sem suspeita de meningite não exibiram bandas no gel da eletroforese. Por outro lado, o DNA obtido por cultura pura, bem como as amostras de LCR de pacientes com meningite confirmada por cultura bacteriana evidenciaram banda compatível com a amplificação do gene 16S rRNA (Figura 3).

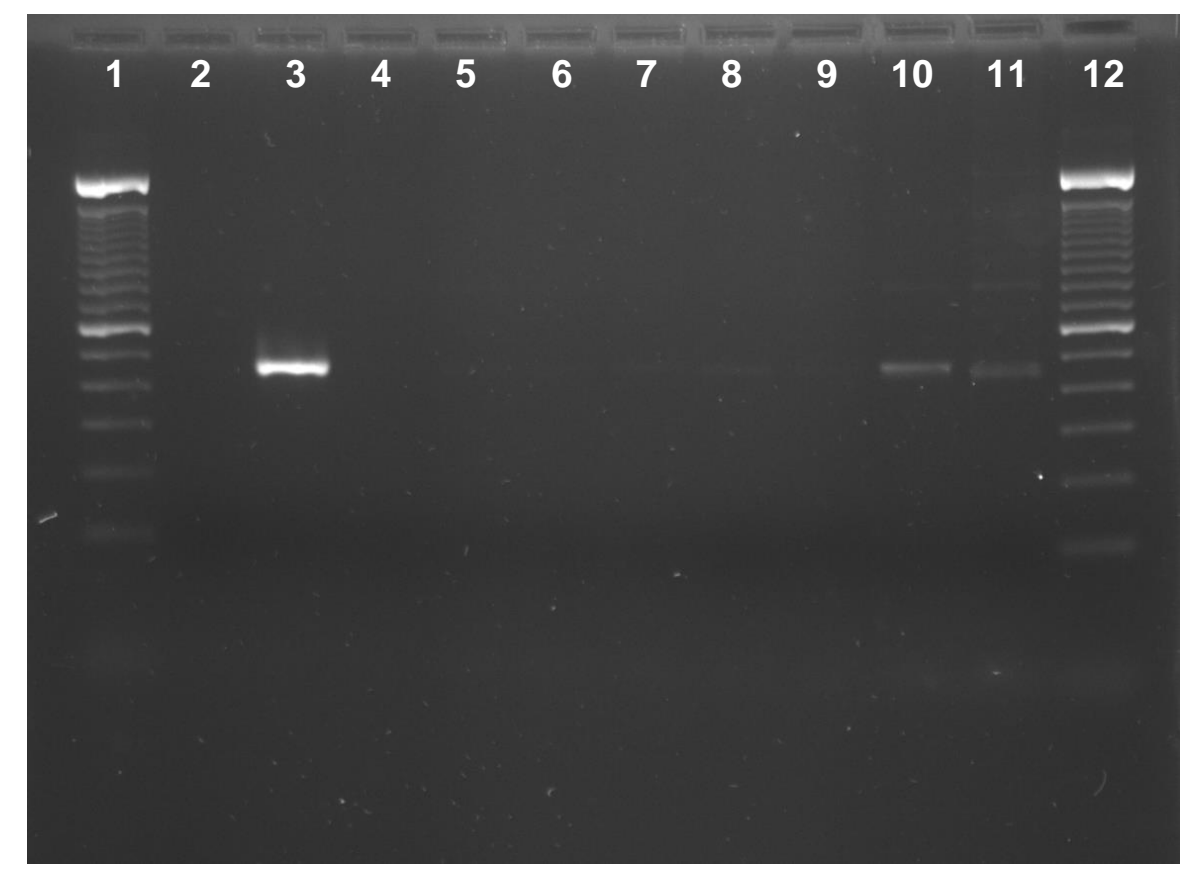

Figura 3 - Eletroforese em gel de agarose 1,5\% dos produtos da reação em cadeia da polimerase (PCR) para 16S rRNA, utilizando os primers 331F e 767R. Colunas: 1) peso molecular de 100 pares de base (Invitrogen $\AA$ Thermo Fisher Scientific); 2) controle negativo (somente reagentes); 3) controle positivo (DNA bacteriano obtido de cultura pura); 4 a 9) amostras negativas; 10 e 11) amostras positivas (LCR com cultura bacteriana positiva; 12) peso molecular 100 pares de base (Invitrogenß Thermo Fisher Scientific). 


\subsubsection{Determinação dos limites de detecção do método de biologia molecular para o diagnóstico de MAN}

Para a determinação dos limites de detecção foram realizados ensaios de quantificação bacteriana, nos quais foram utilizadas como padrão as cepas E. coli ATCC25922 e S. aureus ATCC25923, LCR de pacientes com HPN e com resultado negativo para cultura microbiológica.

Para E. coli ATCC25922, houve detecção em todas as diluições testadas, tanto em PBS quanto em LCR; dessa forma, o método foi capaz de detectar até $10^{2} \mathrm{UFC} / \mathrm{mL}$ (Figura 4A). Para S. aureus ATCC25923, houve detecção a partir da diluição $10 \mathrm{UFC} / \mathrm{mL}$ tanto em PBS quanto em LCR (Figura $4 B)$.

A

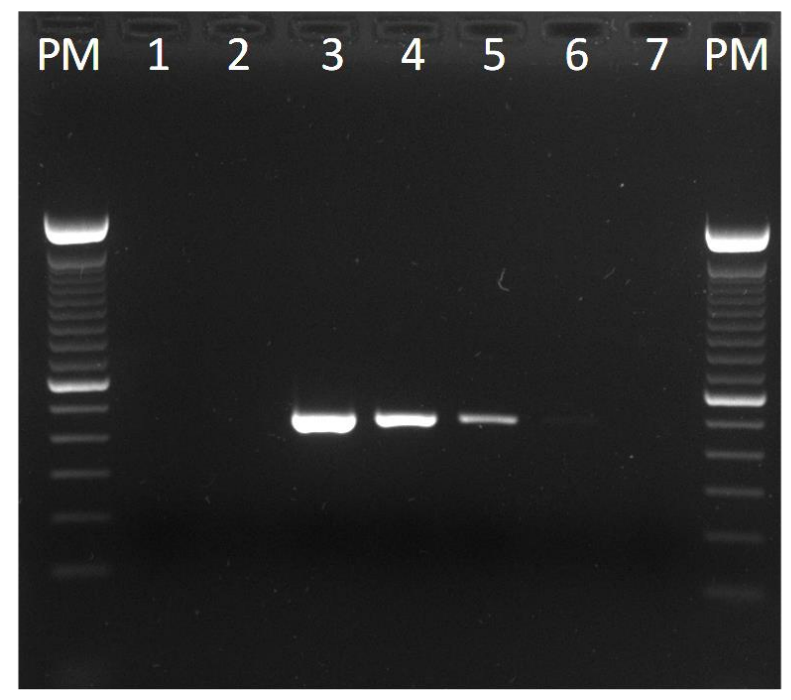

B

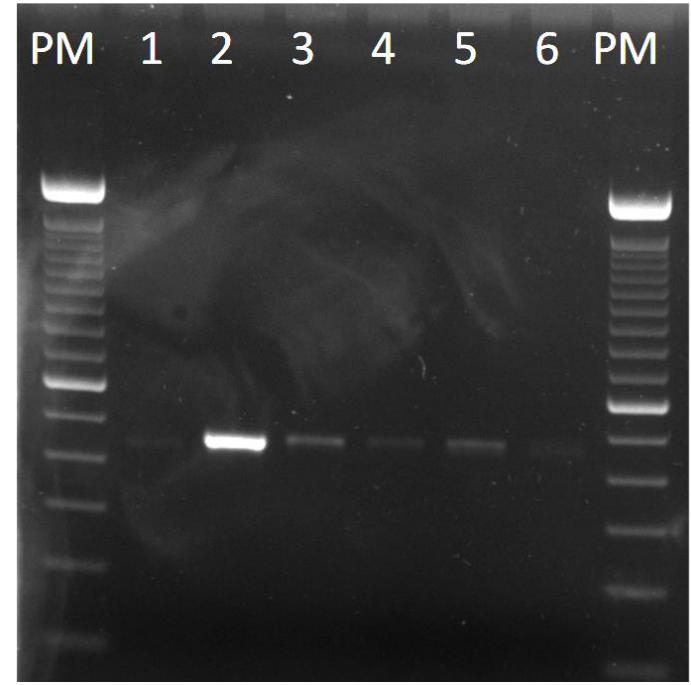

Figura 4 - Limite de detecção para o kit de extração e purificação MagNa Pure Compact Nucleic Acid Isolation Kit; PCR para 16S rRNA, utilizando os primers $331 \mathrm{~F}$ e $767 \mathrm{R}$. Eletroforese em gel de agarose 1,5\% dos produtos de PCR. (A) E. coli ATCC25922/ Colunas: PM) peso molecular 100 pares de base (Invitrogen ${ }^{\circledR}$ Thermo Fisher Scientific); 1) controle negativo mix; 2) amostra LCR puro; 3) amostra $10^{5}$ UFC/mL; 4) amostra $10^{4} \mathrm{UFC} / \mathrm{mL}$; 5) amostra $10^{3} \mathrm{UFC} / \mathrm{mL}$; 6) amostra $10^{2} \mathrm{UFC} / \mathrm{mL}$; 7) amostra $10 \mathrm{UFC} / \mathrm{mL} ; \quad$ (B) $\quad$ S. aureus ATCC25923/Colunas: PM) peso molecular 100 pares de base (Invitrogen ${ }^{\circledR}$ Thermo Fisher Scientific); 1) controle negativo mix; 2) amostra $\left.10^{5} \mathrm{UFC} / \mathrm{mL} ; 3\right)$ amostra $10^{4} \mathrm{UFC} / \mathrm{mL}$; 4) amostra $10^{3}$ $\mathrm{UFC} / \mathrm{mL}$; 5) amostra $10^{2} \mathrm{UFC} / \mathrm{mL} ; 6$ ) amostra $10 \mathrm{UFC} / \mathrm{mL}$ 
O sequenciamento das amostras positivas identificou os mesmos microrganismos, validando assim o experimento.

\subsection{DADOS CLÍNICO-LABORATORIAIS DOS PACIENTES}

Após a validação da PCR para 16S rRNA, o método foi então aplicado a LCR de pacientes atendidos pelo ICHC e pelo IPq, entre janeiro de 2015 e dezembro de 2016. Foram envolvidas 51 amostras de LCR (uma amostra por paciente): 43 de pacientes submetidos à neurocirurgia prévia e 8 de pacientes sem exposição a neurocirurgia, consideradas amostras de pacientes não portadores de meningite.

Entre os pacientes expostos à neurocirurgia $(n=43), 23(53 \%)$ eram do sexo masculino, e a idade média desse grupo foi de 51 anos (intervalo de 18 a 87 anos). Os pacientes incluídos estavam internados no IPq $(n=19)$ e nas seguintes unidades do ICHC: UTI da Neurocirurgia $(n=13)$, UTI do Trauma $(n=10)$ e Geriatria $(n=1)$. Os motivos para a realização de neurocirurgia foram: hidrocefalia $(n=6)$, hemorragia subaracnóide $(n=6)$, traumatismo cranioencefálico $(n=5)$, tumor de sistema nervoso central $(n=4)$, craniofaringioma $(n=3)$, adenoma hipofisário $(n=2)$, acidente vascular cerebral $(n=2)$, cisticercose $(n=2)$, cisto $(n=2)$, hematoma cerebelar $(n=2)$, hematoma intraparenquimatoso $(n=2)$, instabilidade vertebral $(n=2)$, macroadenoma $(n=2)$, glioma $(n=1)$, lesão em IV ventrículo $(n=1)$ e meningioma $(n=1)$. Todos os pacientes neurocirúrgicos receberam profilaxia cirúrgica com cefuroxima. Dos 43 pacientes, 33 (77\%) apresentaram sintomas clínicos sugestivos de meningite, com tempo médio de 9 dias (intervalo de 1 a 54 dias) entre o procedimento e a suspeita clínica (Anexo D).

Os pacientes saudáveis submetidos à cirurgia eletiva com anestesia raquidiana foram selecionados no centro cirúrgico antes da anestesia. Entre os 8 pacientes não expostos a neurocirurgia, 2 (25\%) eram do sexo masculino, e a idade média desse grupo foi de 43 anos (Anexo D).

A celularidade média no LCR dos pacientes submetidos a neurocirurgia foi de 475 células $/ \mathrm{mm}^{3}$ (intervalo de 0 a 4904 céls $/ \mathrm{mm}^{3}$ ) (Figura 5). A proteinorraquia média dos pacientes submetidos a neurocirurgia foi de 163 $\mathrm{mg} / \mathrm{dL}$ (intervalo de 10 a $735 \mathrm{mg} / \mathrm{dL}$ ) (Figura 6). A dosagem média de lactato no 
LCR dos pacientes submetidos a neurocirurgia foi de $44 \mathrm{mg} / \mathrm{dL}$ (intervalo de 11 a $162 \mathrm{mg} / \mathrm{dL}$ ) (Figura 7). Por sua vez, a glicorraquia média destes pacientes foi de $60 \mathrm{mg} / \mathrm{dL}$ (intervalo de 3 a $206 \mathrm{mg} / \mathrm{dL}$ ) (Figura 8).

Quatro pacientes apresentaram cultura positiva. Os microrganismos isolados foram: Klebsiella pneumoniae $(\mathrm{n}=2)$, Staphylococcus haemolyticus $(n=1)$ e Enterobacter cloacae $(n=1)$.

Com estes dados clínicos e achados quimiocitológicos do LCR dos pacientes submetidos a neurocirurgia e não-expostos a neurocirurgia, as amostras então foram classificadas (Tabela 4).

Tabela 4 - Classificação de 51 pacientes expostos e não expostos a neurocirurgia, com relação à probabilidade de apresentarem meningite bacteriana (MB)

\begin{tabular}{lc}
\hline Classificação & Pacientes $(n=51)$ \\
\hline Grupo 1 - MB confirmada & 4 \\
Grupo 2 - MB provável & 6 \\
Grupo 3 - MB possível & 9 \\
Grupo 4 - MB improvável & 24 \\
Grupo 5 - Sem MB & 8 \\
\hline
\end{tabular}




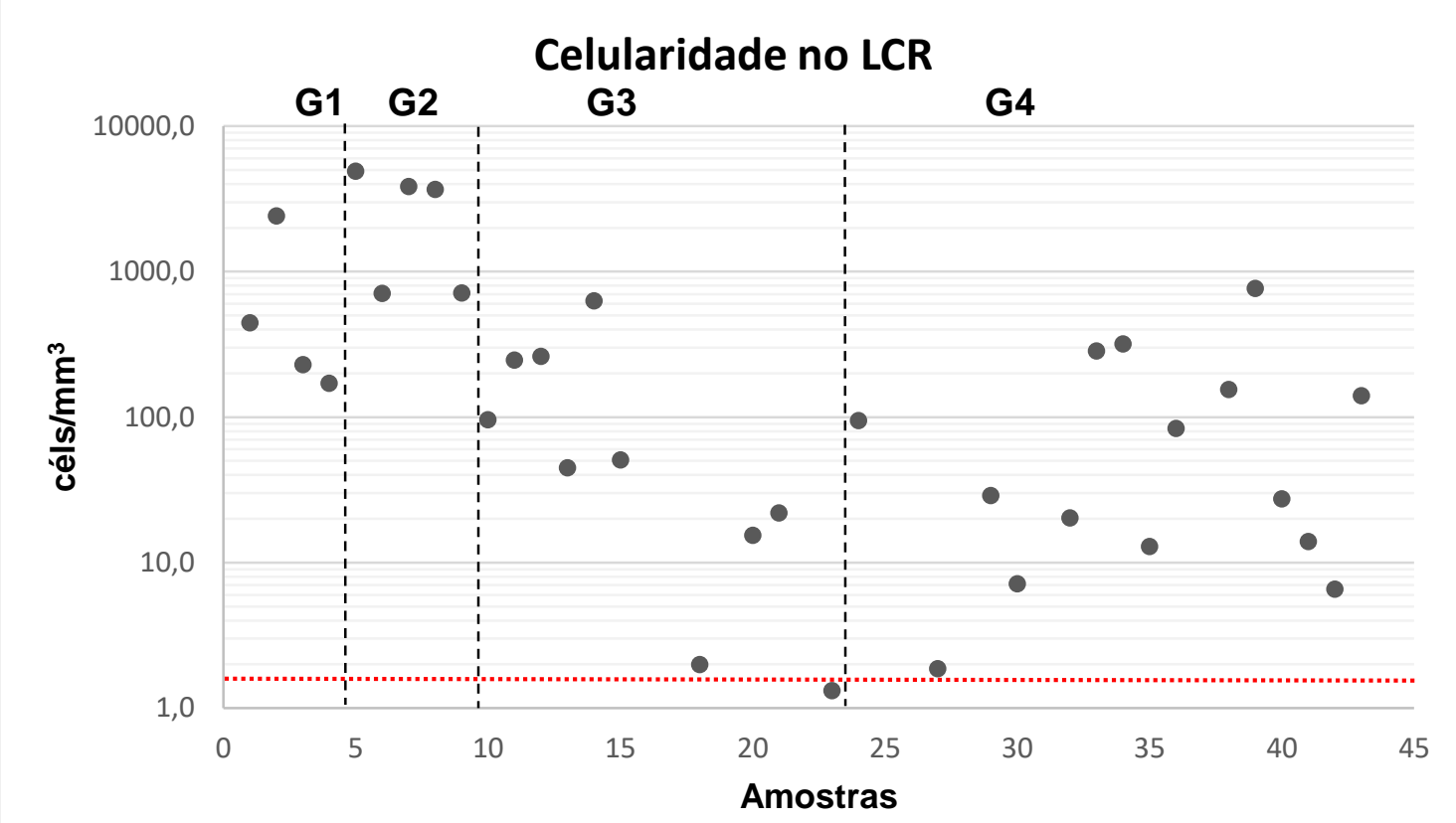

G1 - Grupo 1 MB confirmada; G2 - Grupo 2 MB provável; G3 - Grupo 3 MB possível; G4 Grupo 4 MB improvável. Valor de referência da celularidade no LCR: até 4 células/ $\mathrm{mm}^{3}$ (linha pontilhada)

Figura 5 - Celularidade liquórica de 43 pacientes submetidos à neurocirurgia e com probabilidade de diagnóstico de meningite bacteriana

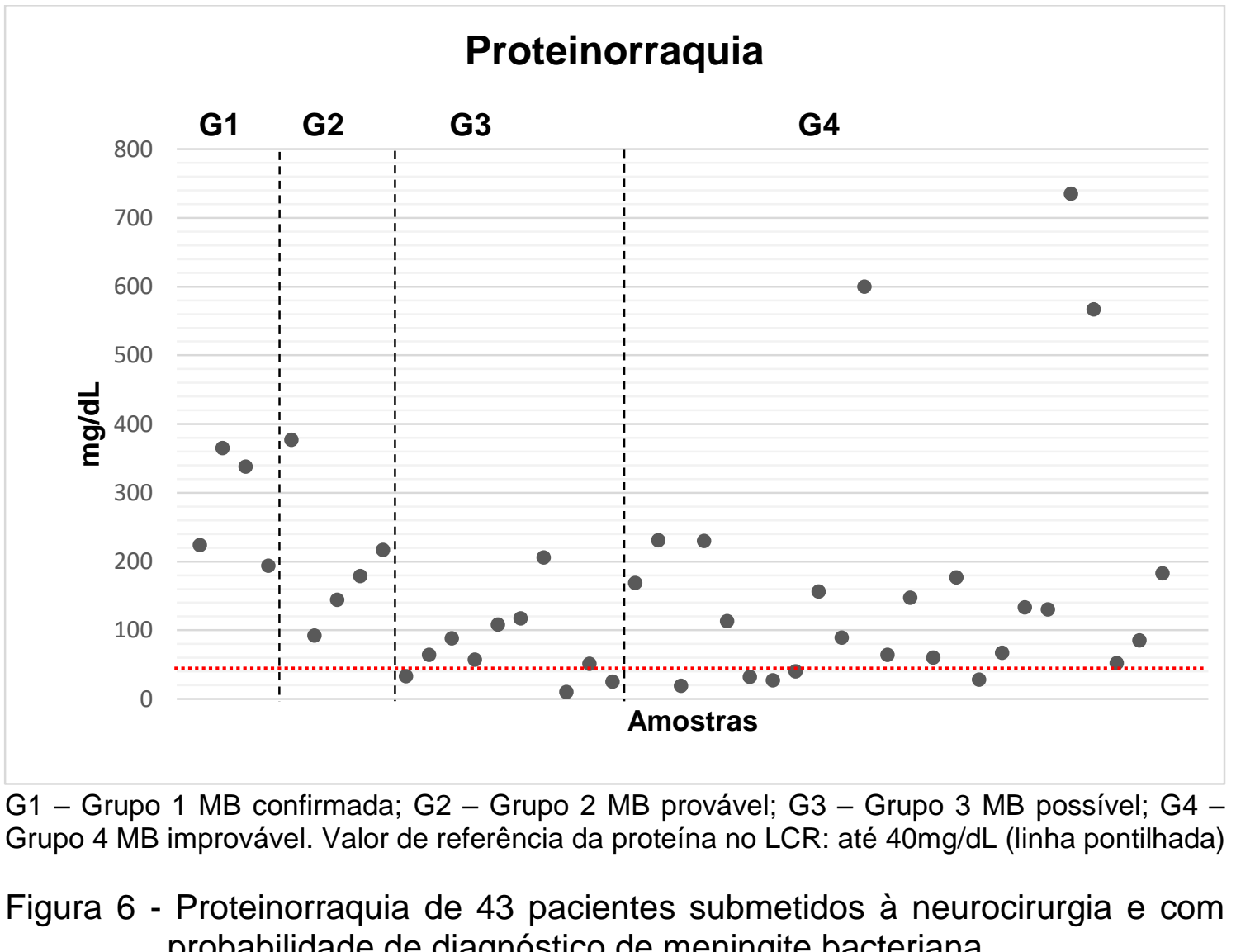
probabilidade de diagnóstico de meningite bacteriana 


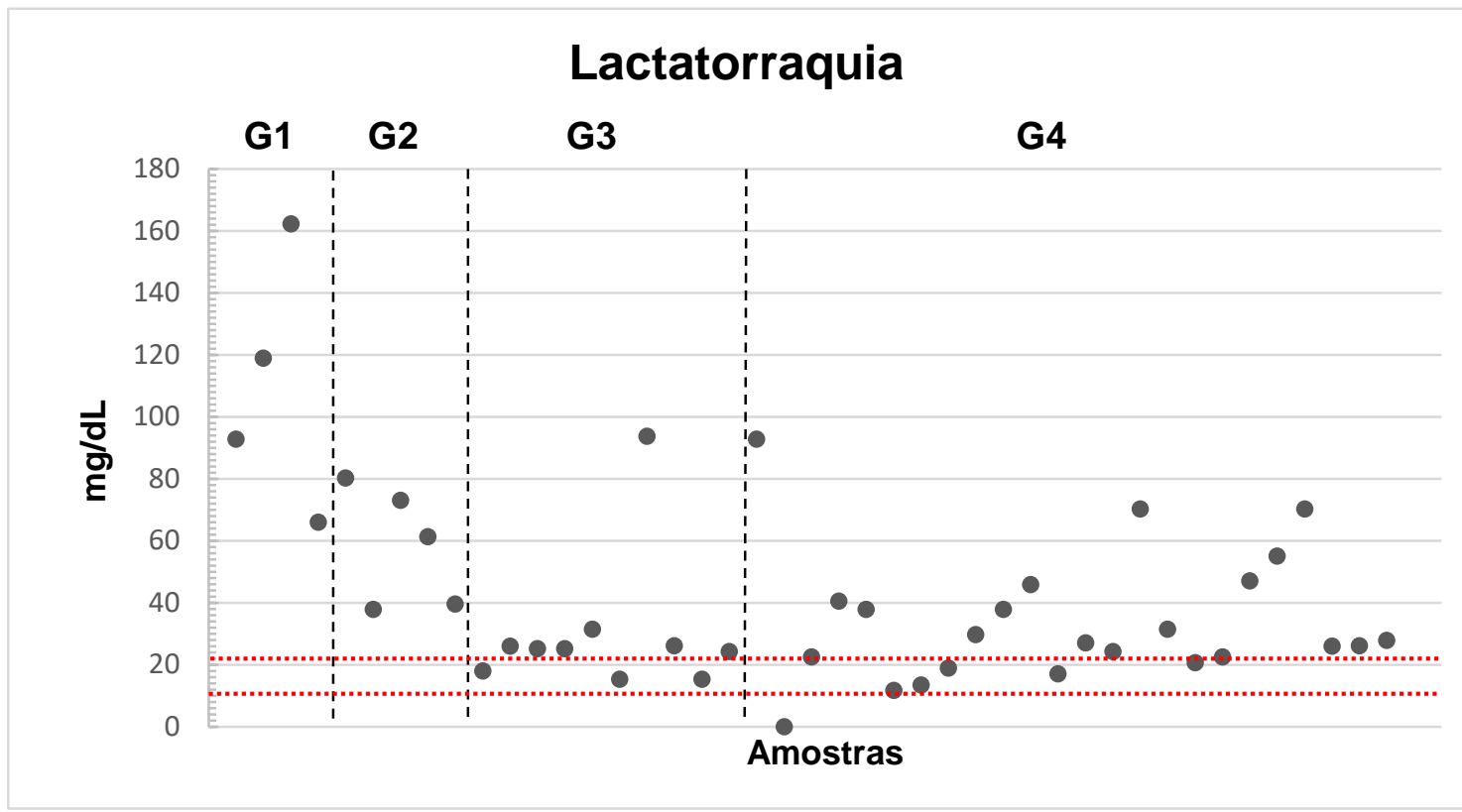

G1 - Grupo 1 MB confirmada; G2 - Grupo 2 MB provável; G3 - Grupo 3 MB possível; G4 Grupo 4 MB improvável. Valores de referenciado lactato no LCR: 10-22mg/dL (linha pontilhada)

Figura 7 - Lactatorraquia de 43 submetidos à neurocirurgia e com probabilidade de diagnóstico de meningite bacteriana

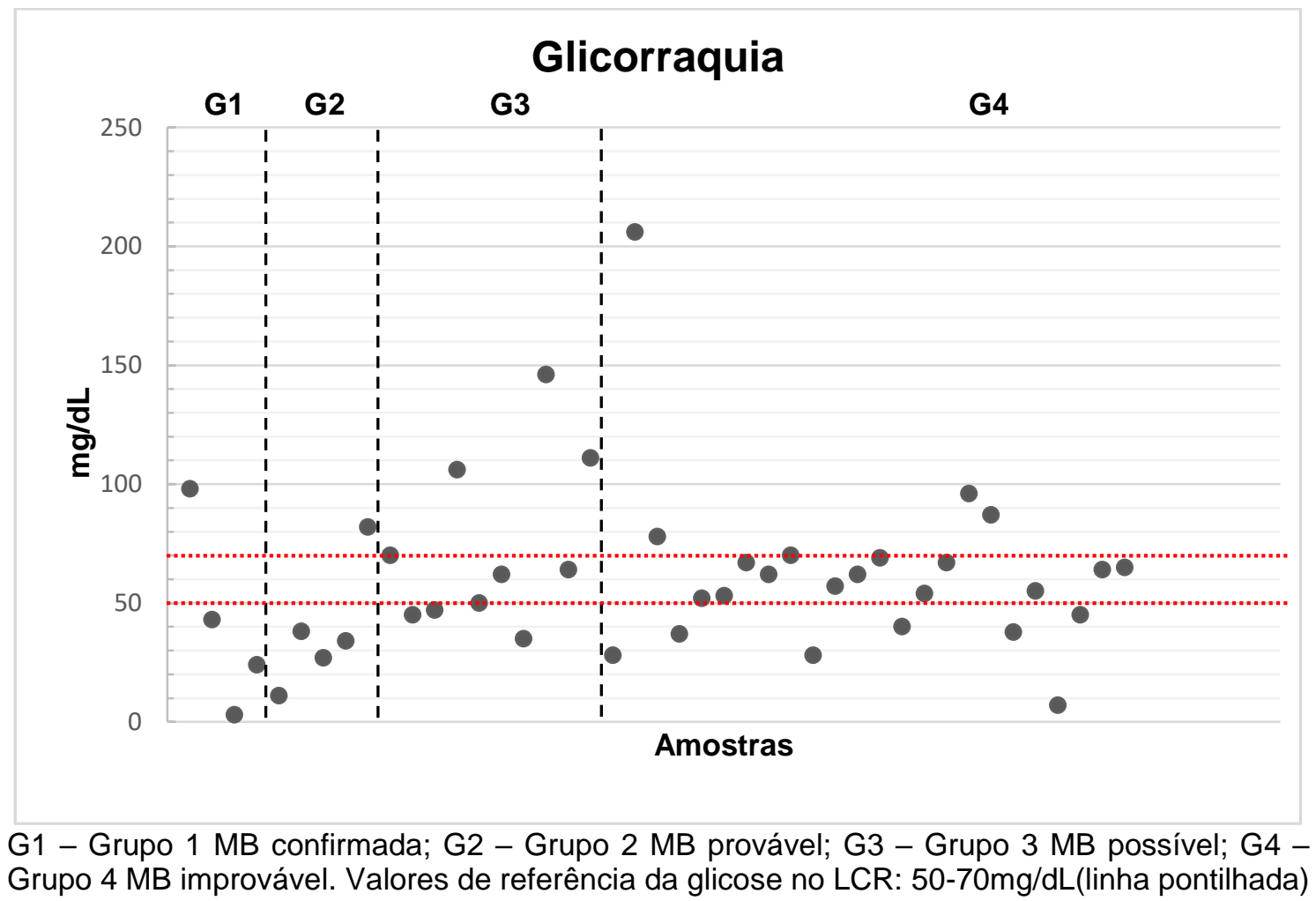

Figura 8 - Glicorraquia de 43 pacientes submetidos à neurocirurgia e com probabilidade de diagnóstico de meningite bacteriana 


\subsection{APLICAÇÃO DO MÉTODO DE BIOLOGIA MOLECULAR EM AMOSTRAS DE LCR DE PACIENTES COM SUSPEITA DE MAN}

Para o protocolo de aplicação do método molecular, as amostras coletadas para a pesquisa seguiram o fluxograma descrito na figura abaixo (Figura 9). O total de amostras foi de 51 LCR de pacientes expostos e não expostos à neurocirurgia. Dentre as 43 amostras de LCR dos pacientes submetidos a neurocirurgia, a PCR foi positiva em 23 amostras. Oito destas amostras apresentaram no gel de eletroforese uma segunda banda, mais discreta e muito próxima à do gene 16S rRNA alvo. Entre as 8 amostras de LCR de pacientes não expostos a neurocirurgia, 7 se mostraram negativas à PCR, mas em 1 foi evidenciada banda compatível com a amplificação do gene $16 \mathrm{~S}$ rRNA e também uma segunda banda.

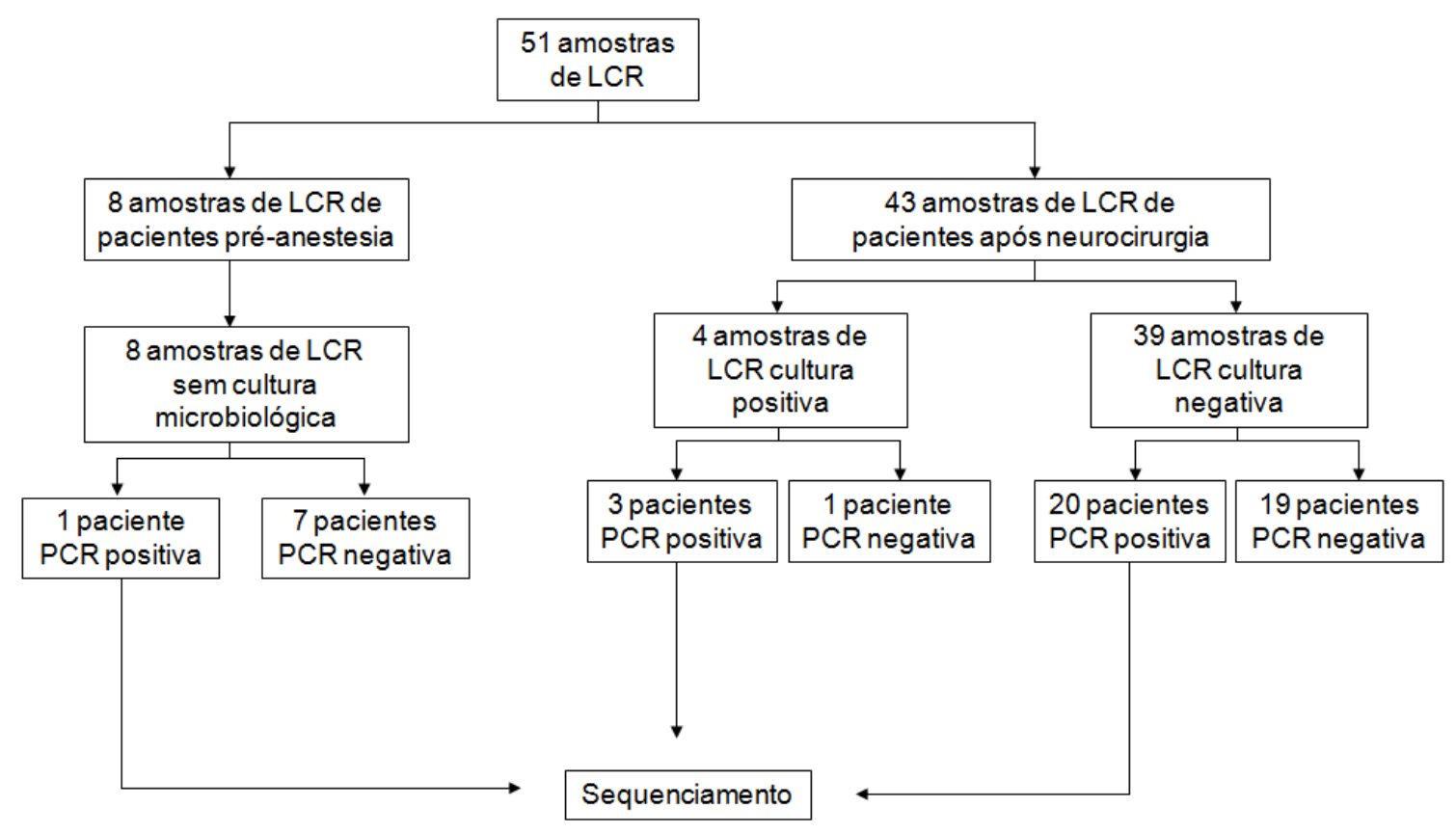

Figura 9 - Fluxograma demonstrando o direcionamento das amostras de acordo com o paciente, a cultura microbiológica e resultado da reação em cadeia da polimerase (PCR) para o gene 16S RNA ribossomal

O sequenciamento do produto da PCR de duas amostras positivas não discriminou com exatidão o microrganismo causador da infecção, pois apesar das altas cobertura e identidade de $97 \%$, $98 \%$ e $99 \%$ respectivamente, o 
sequenciamento foi consenso para seis espécies. Em 12 amostras, no entanto, a discriminação foi possível, três destas amostras foram positivas em cultura e a identificação laboratorial coincidiu com o microrganismo encontrado na análise da sequência, os microrganismos concordantes encontrados foram: Enterobacter cloacae, Klebsiella pneumoniae e Staphylococcus haemolyticus. Por outro lado, a análise do produto do PCR das amostras que apresentaram uma segunda banda próxima à do gene $16 \mathrm{~S}$ rRNA, não foi discriminatória para nenhum microrganismo, mesmo após o alinhamento e troca das possíveis bases duvidosas.

Uma amostra de LCR, positiva em cultura, apresentou a PCR negativa. Por outro lado, uma amostra dos pacientes sem suspeita de meningite foi positiva na PCR (Figura 9).

Os microrganismos mais prováveis identificados no sequenciamento estão descritos na Tabela 5. 
Tabela 5 - Microrganismos mais prováveis encontrados no líquido cefalorraquidiano (LCR) de 51 pacientes expostos e não expostos à neurocirurgia identificados no sequenciamento

\begin{tabular}{|c|c|c|c|c|c|}
\hline Paciente & Unidade & Grupo & Cultura & PCR16S & Sequenciamento \\
\hline 1 & $\mathrm{IPq}$ & 4 & - & + & Granulicatella adiacens \\
\hline 2 & NEU & 2 & - & - & - \\
\hline 3 & $\mathrm{IPq}$ & 3 & - & + & Granulicatella adiacens \\
\hline 4 & ANE & 5 & - & - & - \\
\hline 5 & TRA & 2 & - & - & - \\
\hline 6 & TRA & 4 & - & + & Sem consenso \\
\hline 7 & TRA & 4 & - & + & Sem consenso \\
\hline 8 & NEU & 4 & - & + & Variovorax paradoxos \\
\hline 9 & $\mathrm{IPq}$ & 3 & - & - & - \\
\hline 10 & NEU & 3 & - & + & - \\
\hline 11 & $\mathrm{IPq}$ & 3 & - & - & - \\
\hline 12 & TRA & 4 & - & + & Acinetobacter baumannii \\
\hline 13 & $\mathrm{IPq}$ & 2 & - & + & Variovorax boronicumulans \\
\hline 14 & ANE & 5 & - & + & Sem consenso \\
\hline 15 & ANE & 5 & - & - & - \\
\hline 16 & TRA & 3 & - & + & - \\
\hline 17 & $\mathrm{IPq}$ & 4 & - & - & - \\
\hline 18 & $\mathrm{IPq}$ & 1 & + & + & Enterobacter cloacae \\
\hline 19 & ANE & 5 & - & - & - \\
\hline 20 & $\mathrm{IPq}$ & 2 & - & + & Variovorax boronicumulans \\
\hline 21 & TRA & 4 & - & - & - \\
\hline 22 & ANE & 5 & - & - & - \\
\hline 23 & $\mathrm{IPq}$ & 4 & - & - & - \\
\hline 24 & $\mathrm{IPq}$ & 2 & - & - & - \\
\hline 25 & TRA & 4 & - & - & - \\
\hline 26 & GER & 3 & - & - & - \\
\hline 27 & NEU & 4 & - & - & - \\
\hline 28 & $\mathrm{IPq}$ & 1 & + & + & Staphylococcus haemolyticus \\
\hline 29 & TRA & 4 & - & - & - \\
\hline 30 & NEU & 3 & - & - & - \\
\hline 31 & $\mathrm{IPq}$ & 4 & - & - & - \\
\hline 32 & NEU & 2 & - & + & Enterococcus cecorum \\
\hline 33 & NEU & 4 & - & + & Enterobacteriaceae \\
\hline 34 & $\mathrm{IPq}$ & 4 & - & - & - \\
\hline 35 & NEU & 4 & - & + & - \\
\hline 36 & $\mathrm{IPq}$ & 1 & + & + & Klebsiella pneumoniae \\
\hline 37 & NEU & 4 & - & - & - \\
\hline 38 & ANE & 5 & - & - & - \\
\hline 39 & TRA & 4 & - & - & - \\
\hline 40 & $\mathrm{IPq}$ & 4 & - & + & Enterobacter cloacae \\
\hline 41 & NEU & 4 & - & + & - \\
\hline 42 & TRA & 4 & - & + & Enterobacteriaceae \\
\hline 43 & $\mathrm{IPq}$ & 4 & - & - & - \\
\hline 44 & $\mathrm{IPq}$ & 3 & - & + & Pseudomonas aeruginosa \\
\hline 45 & NEU & 3 & - & - & - \\
\hline 46 & ANE & 5 & - & - & - \\
\hline 47 & $\mathrm{IPq}$ & 1 & + & - & - \\
\hline 48 & NEU & 4 & - & + & Pseudomonas aeruginosa \\
\hline 49 & ANE & 5 & - & - & - \\
\hline 50 & NEU & 4 & - & + & - \\
\hline 51 & $\mathrm{IPq}$ & 4 & - & + & Sem consenso \\
\hline
\end{tabular}




\subsection{COMPARAÇÃO DOS RESULTADOS DAS PCR POSITIVAS COM AS PCR NEGATIVAS DOS PACIENTES SUBMETIDOS A NEUROCIRURGIA}

Para avaliar se os achados quimiocitológicos entre os grupos PCR positiva e negativa diferem, foram comparados então os achados liquóricos dos pacientes expostos a neurocirurgia com LCR positivo à PCR com os achados liquóricos de pacientes com LCR negativo à PCR. Nenhum dos parâmetros mostrou diferença estatisticamente significativa entre os grupos PCR positiva e PCR negativa (Tabela 6).

Tabela 6 - Comparação entre os parâmetros quimiocitológicos do líquido cefalorraquidiano (LCR) de amostras com resultado da reação em cadeia da polimerase (PCR) positiva e negativa

\begin{tabular}{lccc}
\hline PARÂMETRO * & PCR positiva & PCR negativa & Valor de $\boldsymbol{p}$ \\
\hline Celularidade $\left(\text { por } \mathrm{mm}^{3}\right)^{*}$ & $450(904)$ & $504(1320)$ & 0.88 \\
Proteinorraquia $(\mathrm{mg} / \mathrm{dL})^{*}$ & $171(153)$ & $153(171)$ & 0.70 \\
Lactato liquórico $(\mathrm{mg} / \mathrm{dL})^{*}$ & $50(37)$ & $38(24)$ & 0.23 \\
Glicorraquia $(\mathrm{mg} / \mathrm{dL})^{*}$ & $63(39)$ & $57(33)$ & 0.59 \\
\hline
\end{tabular}

* Média (desvio padrão) 


\section{DISCUSSÃO}

O diagnóstico de MAN é um desafio. Em nosso estudo, foi proposto um teste diagnóstico para facilitar a identificação de MAN, e desta maneira facilitar o seu tratamento.

Atualmente, o diagnóstico das meningites pós-operatórias está baseado nas normas e diretrizes práticas do Infectious Diseases Society of America (IDSA), desenvolvidas por um comitê de 10 especialistas mundiais em doenças infecciosas do SNC associadas à assistência à saúde, como meningites e ventriculites. Estes critérios têm por objetivo guiar a tomada de decisão clínica, abordando de maneira prática e útil o tratamento destas infecções, aliando os resultados laboratoriais do LCR com sintomas clássicos como dores de cabeça, sinais meníngeos e febre maior que $37,8^{\circ} \mathrm{C}$ (Tunkel et al., 2017). No entanto, muitas vezes isso não é suficiente para esclarecer a etiologia correta desta doença, apenas o seu manejo.

A maioria dos laboratórios clínicos não abrange a identificação de alguns microrganismos, pois estes são de difícil cultivo não sendo isolados na cultura microbiológica do LCR durante a rotina laboratorial. Os principais motivos para isso são: a falta de recursos na área da microbiologia clínica para a cultura bacteriana, incluindo alguns microrganismos mais exigentes nutricionalmente, como por exemplo, o Mycobacterium tuberculosis; uma gestão fora das normas de controle de qualidade nos serviços de microbiologia laboratorial; e a administração de antimicrobianos de forma empírica antes da realização da punção lombar para o diagnóstico de MAN (Sacchi et al., 2011).

Logo após uma neurocirurgia, pode ocorrer uma inflamação asséptica das meninges, que tem grande semelhança à meningite bacteriana do ponto de vista dos sintomas e alterações liquóricas, devido à reabsorção sanguínea e manipulação tecidual do SNC, assim como febre, meningismo e alteração do nível de consciência (Ramos-Martínez et al., 2009). Portanto, diferenciar estas duas condições pode ser complexo. A contagem de leucócitos e os níveis de glicose não mostraram diferença significativa entre as meningites bacteriana e asséptica segundo Liu e colaboradores em sua pesquisa de 2015. Alguns trabalhos tentam correlacionar a dosagem de fatores pró inflamatórios que 
poderiam estar associados à meningite bacteriana. $\mathrm{O}$ estudo conduzido por López-Cortés e colaboradores em 2000 demonstrou que a dosagem de interleucina-1 $\beta$ (IL-1 $\beta$ ) foi o melhor marcador inflamatório pós-neurocirurgia. Liu e colaboradores em 2015, avaliaram os marcadores inflamatórios: fator de necrose tumoral (TNF- $\alpha$ ), interleucina-1 $\beta$ (IL-1 $\beta$ ), interleucina-6 (IL-6) e interleucina-8 (IL-8), que tiveram seus níveis aumentados no LCR quatro dias antes do início do quadro febril causado pela meningite bacteriana, demonstrando a possibilidade de acompanhamento destes marcadores inflamatórios em casos de suspeita de meningite e desta maneira encontrar valores preditivos. Já outro trabalho de 2014 produzido por Liu e colaboradores sugere que altos níveis do receptor chamariz 3 (DcR3), que é um fragmento do TNF- $\alpha$, seriam prognóstico de meningite bacteriana pós-neurocirurgia.

Os níveis de lactato no líquor também foram propostos como um método para diferenciar meningite asséptica e MAN. Durante a infecção, o metabolismo bacteriano, a glicólise de neutrófilos e ainda o metabolismo anaeróbico do tecido cerebral levam ao acúmulo de lactato no LCR. Por estes motivos, foi concluído que o lactato é confiável para caracterizar esta enfermidade. (Maskin et al., 2013). Outro parâmetro testado na literatura foi a procalcitonina (PCT), que é um pró-hormônio da calcitonina liberado pelo parênquima celular das células $C$ da tireoide na presença de lipopolissacarídeos bacterianos, endotoxinas e citocinas inflamatórias como IL-6 e TNF-a (Foushee; Hope; Grace, 2012; Alons et al., 2016). Segundo Alons e colaboradores (2016), a PCT é um biomarcador com grande utilidade especialmente nos pacientes pós-neurocirúrgicos, pois há aumento da sua produção quando existe suspeita de meningite bacteriana. No entanto, apesar das evidências supracitadas, testes que evidenciem a presença do microrganismo no SNC, baseados ou não em cultura, tem se mostrado mais precisos para o diagnóstico da meningite.

A análise quimiocitológica do LCR foi utilizada para avaliar o paciente com suspeita de MAN. A Figura 5 demonstra que 93\% das amostras apresentaram alteração na celularidade, sendo que os grupos que exibiram a maior discrepância no número de células por $\mathrm{mm}^{3}$ de LCR foram: G1 MB confirmada e G2 MB provável com níveis entre $10^{2}$ e $10^{3}$ células por $\mathrm{mm}^{3}$. Mas, em casos suspeitos de MAN esta medida pode estar alterada devido a 
inflamação e manipulação tecidual após a neurocirurgia principalmente nos casos no qual houve sangramento do SNC (Schade et al., 2006; Boszczowski e Bermudez 2016). Já para a proteinorraquia, $83 \%$ das amostras de LCR estiveram acima do valor de referência (Figura 6), porém os valores mais altos para a proteinorraquia pertenceram ao grupo G4 MB improvável, e não aos grupos G1 MB confirmado e G2 MB provável como esperado devido ao processo infeccioso. $\mathrm{Na}$ avaliação da lactatorraquia entre os grupos, a Figura 7 , mostra que $77 \%$ das amostras de LCR, demonstraram níveis de lactato acima dos valores de referência, sendo estas amostras pertencentes a todos os grupos classificados. Estudos têm demonstrado que a lactatorraquia tem sensibilidade e especificidade suficientes para ser considerado um dos testes diagnósticos de MAN (van de Beek; Drake, Tunkel, 2010; Maskin et al., 2013; Tunkel et al., 2017). E a dosagem de glicose no LCR na Figura 8 revelou que 40\% das amostras estiveram abaixo dos valores de referência, o que demonstra que a glicose foi metabolizada no LCR que é característico de um quadro clínico de meningite bacteriana (Schade et al., 2006; Tunkel et al., 2017). Um estudo prospectivo com 28 LCR pacientes pós neurocirúrgicos, publicado em 2006 por Tavares e colaboradores, na Universidade de São Paulo demonstrou que os parâmetros do LCR: celularidade, lactato e glicose são úteis para diferenciar meningite bacteriana de asséptica, mas não são conclusivos para o diagnóstico.

$\mathrm{Na}$ década de 1990, foram feitas as primeiras tentativas para desenvolver métodos moleculares para testes em LCR (Greisen et al., 1994; Salord et al., 1995; Druel et al., 1996). Um estudo, em 1996, avaliou a presença de bactérias utilizando o método de PCR em LCR de pacientes com suspeita de meningite pós-operatória. As amostras apresentaram resultado negativo para cultura microbiológica, e com a aplicação deste método as mesmas demostraram-se positivas para a amplificação do gene 16S rRNA, sugerindo que este gene poderia ser utilizado como ferramenta diagnóstica nestes casos (Druel et al., 1996). Salord e colaboradores (1995) sugeriram que os casos em que a meningite foi considerada asséptica, poderiam, na realidade, ser meningites bacterianas causadas por microrganismos fastidiosos ou por baixas cargas bacterianas indetectáveis por PCR qualitativo. 
Com o atual estabelecimento da biologia molecular como uma das principais ferramentas no diagnóstico e manejo de doenças infecciosas, a rapidez e a sensibilidade destes métodos são características atrativas na liberação de resultados.

Os laboratórios de microbiologia clínica têm utilizado estes métodos moleculares principalmente em dois casos: i) para melhorar a detecção de microrganismos em situações clínicas de emergência, no qual os métodos fenotípicos não são capazes de identificar um agente, porque o patógeno é fastidioso e/ou não cultivável; ii) nos casos em que o paciente recebeu uma cobertura antimicrobiana empírica, muitas vezes de amplo espectro, antes da coleta e submissão de material clínico para análise (Sibley; Peirano; Church, 2012).

A PCR muitas vezes possui um papel investigativo significativo para uma ampla gama de doenças infecciosas, como se fosse uma "placa de petri molecular" para identificar causas infecciosas emergentes ou existentes para doenças descritas como idiopáticas. O DNA amplificado usando esta abordagem de amplo alcance pode conter sequências genéticas específicas para um único microrganismo, ou para determinado grupo quando comparadas com o genoma microbiano existente em bases de dados como, por exemplo, a base do NCBI (Yang; Rothman, 2004).

O gene 16S rRNA é um excelente alvo a ser pesquisado no LCR de pacientes submetidos a neurocirurgia devido às suas características conservadas e variáveis, além de ser o gene marcador taxonômico mais sequenciado das últimas décadas (Yarza et al., 2014). E por este motivo o trabalho foi desenvolvido em duas etapas: a padronização do teste de biologia molecular para o diagnóstico de MAN em amostra de LCR inoculadas previamente com bactérias, e a aplicação do método padronizado para 0 diagnóstico de MAN em pacientes expostos e não expostos à neurocirurgia.

Durante a validação do método de amplificação do gene $16 \mathrm{~S}$ rRNA, também foi determinado o limite de detecção do método para o diagnóstico de MAN. O método aqui testado envolveu a retirada de LCR de pacientes com HPN submetidos ao Tap Test e sua inoculação com bactérias padrão ATCC. Alguns trabalhos utilizaram "pool" de amostras negativas de LCR para definir o limite de 
detecção da metodologia a ser padronizada (Jalava; Jalava, 2002; Zakaria; Mohamad; Suraiya, 2016). Estes autores encontraram um limite de detecção para microrganismos padrão ATCC Gram positivos que variou entre as diluições $10^{1}$ até $10^{4} \mathrm{UFC} / \mathrm{mL}$, correspondendo ao limite de detecção encontrado no presente estudo. Não conhecemos nenhuma pesquisa prévia utilizando LCR de pacientes com HPN para definir os limites de detecção da metodologia a ser padronizada.

Um estudo apontou que $49 \%$ das culturas de LCR que se mostraram negativas pelos métodos de cultura convencionais, foram positivas quando analisadas por biologia molecular utilizando o gene 16S rRNA (Banks et al., 2005). No presente estudo esta porcentagem foi semelhante, dentre as amostras negativas de LCR para cultura microbiológica, 48,7\% destas foram positivas para o gene 16S rRNA. Uma pesquisa mais recente de 2017 de Dabrsowski e colaboradores reportou que a detecção do gene 16S rRNA deve ser complementar, pois os exames hospitalares de rotina não fornecem uma detecção rápida e eficiente da infecção do SNC por bactérias relacionadas ao dispositivo ventricular externo, que é uma das formas que os microrganismos presentes na pele têm acesso ao SNC. Por outro lado, Zarrouk e colaboradores (2010) demonstraram que a detecção de 16S rRNA por PCR no LCR, teve um desempenho pior do que a detecção de agentes em culturas microbiológicas. Foi constatado que em apenas metade dos seis casos de meningite deste estudo houve cultura de LCR positiva a partir da punção lombar, nos outros três casos restantes ocorreram culturas positivas a partir da ferida ou do vazamento de LCR (Zarrouk et al., 2010).

Em 2007 Deutch e colaboradores avaliaram o uso de RT-PCR utilizando primers $16 \mathrm{~S}$ rRNA, em LCR de pacientes com suspeita de meningite bacteriana relacionada a dispositivos de drenagem ventricular. A RT-PCR diagnosticou cinco amostras positivas que eram negativas pela cultura microbiológica de um total de 16 infecções já confirmadas microbiologicamente, concluindo que este teste molecular deveria ser considerado complementar à cultura convencional do LCR (Deutch et al., 2007). Já outro estudo, também utilizando RT-PCR, demonstrou que em 62 amostras de LCR de pacientes com dispositivo de drenagem ventricular se obteve uma concordância em 57 amostras (91\%) entre 
os resultados da cultura microbiológica do LCR e um teste comercial de RT-PCR multiplex que detecta 25 bactérias e fungos patogênicos (SeptiFast, Roche, Manheim, Alemanha). Apenas um caso de cultura microbiológica negativa foi positivo para RT-PCR e, em quatro casos o resultado negativo para RT-PCR foi positivo para cultura microbiológica (Rath et al., 2014). Nestes dois estudos, foi utilizada a mesma técnica molecular que possui excelente sensibilidade, mas no final os grupos obtiveram resultados diferentes. No presente estudo não se utilizou uma técnica molecular tão sensível quanto o RT-PCR, porém, pela técnica convencional de PCR foi encontrada a presença do gene 16S rRNA em 20 amostras de LCR, que eram negativas pela cultura microbiológica.

A partir do teste diagnóstico proposto no presente trabalho, observou-se que no grupo G1 MB confirmada três amostras de LCR foram positivas tanto pela cultura microbiológica quanto pela técnica molecular. Foi possível identificar três microrganismos: Enterobacter cloacae, Klebsiella pneumoniae e Staphylococcus haemolyticus, este último, é uma espécie classificada em um grupo denominado Staphylococcus coagulase negativa (SCN), no qual compreendem outras espécies como Staphylococcus epidermidis (Takeuchi et al., 2005). Estas espécies são frequentemente encontradas em culturas microbiológicas de LCR de pacientes neurocirúrgicos e estão presentes nas listas dos possíveis agentes patogênicos bacterianos causadores das MAN, sendo frequentemente encontrado o grupo do SCN (Palabiyikoglu et al., 2006; Deutch et al., 2007; Ramos-Martinez 2009; Chang et al., 2010; Kourbeti et al., 2011; Maskin et al., 2013; Rath et al., 2014; Munoz-Gomez et al., 2015).

No grupo G2 MB provável verificou-se que três amostras também foram positivas apenas pelo método molecular e foram identificadas duas amostras como Variovorax boronicumulans e uma Enterococcus cecorum. A espécie Variovorax boronicumulans é um microrganismo ambiental proveniente do solo (Miwa et al., 2008), e não foi encontrado até o momento nenhuma associação com infecções humanas. Já a espécie Enterococcus cecorum foi relacionada a 6 casos clínicos de infecções humanas em todo o mundo: uma infecção urinária na França (Delaunay; Abat; Rolain, 2015), dois casos de peritonite sendo um em Taiwan (Hsueh et al., 2000) e outro na Bélgica (De Baere et al., 2000), um relato de empiema pleural na China (Woo et al., 2004), um caso de septicemia Suíça 
(Greub et al.,1997) e um relato de endocardite infecciosa no Reino Unido (Ahmed et al., 2011).

No entanto, para o grupo G3 MB possível, o teste molecular foi eficaz apenas para duas amostras. Foram identificados dois microrganismos: Pseudomonas aeruginosa e Granulicatella adiacens. Ambas as espécies já foram relacionadas a infecções do SNC. Sendo que, o microrganismo Pseudomonas aeruginosa é um dos agentes patogênicos mais prevalentes em pacientes com infecções associadas a assistência à saúde e também em ambientes hospitalares como UTIs (Palabiyikoglu et al., 2006). Já a Granulicatella adiacens foi associada às infecções do SNC após neurocirurgias em dois estudos de caso por Cerceo e colaboradores em 2004.

No grupo G4 MB improvável o teste foi positivo para cinco do total de 24 amostras. As identificações dos agentes patogênicos destas amostras demonstraram a presença de: Granulicatella adiacens, Pseudomonas aeruginosa, Acinetobacter baumannii e Variovorax paradoxos. Mas ainda, dentre estas cinco amostras analisadas, duas delas apresentam identificação concordante para mais de uma espécie de microrganismo em uma mesma amostra: Escherichia coli, Escherichia fergusonii, Escherichia vulneris, Shigella flexneri, Shigella sonnei, Brenneria alni. Estas seis espécies pertencem à uma mesma família filogenética, as Enterobacteriaceae, motivo este pelo qual existem correspondências entre seus DNAs. Os genomas dos agentes $E$. coli e Shigella sp. possuem entre 70 e 100\% de homologia do DNA (Gaastra et al., 2014). Já o microrganismo Escherichia fergusonii, é a espécie mais próxima da Escherichia coli com 64\% de similaridade entre seus DNAs (Lawrence et al., 1991), podendo ser encontrado em animais, como aves, produtos de origem animal e suas fezes. Porém, alguns trabalhos isolaram E. fergusonii de pacientes clínicos a partir de infecções do trato urinário (Savini et al., 2008, Bours et al., 2010, Lagacé-Wiens et al., 2010), infecção de corrente sanguínea (Freney et al., 1987), pacientes com câncer pancreático (Funke et al., 1993, Lai et al., 2011) e endoftalmite crônica após cirurgia de catarata (Gokhale et al., 2014). Já os agentes infecciosos Gram negativos não fermentadores ganharam grande importância nos últimos anos pois são patógenos hospitalares, capazes de adquirir resistência a antimicrobianos de amplo espectro complicando ainda mais 
o manejo do paciente neurocirúrgico (Erdem et al., 2008; Ramos-Martínez et al., 2009).

Durante a aplicação do teste diagnóstico, das 24 amostras de LCR de pacientes expostos e não expostos à neurocirurgia que se mostraram positivas na PCR para o gene 16S rRNA, nove delas apresentaram no gel de eletroforese uma segunda banda, mais discreta e muito próxima ao tamanho do gene alvo. Existe a possibilidade destas amostras que apresentaram esta ocorrência, ser polimicrobiana.

Das 15 amostras identificadas pelo sequenciamento, houve um predomínio de bactérias Gram negativas. Este fato corrobora com estudos no qual demonstram que estes tipos de agentes patogênicos, são frequentemente encontrados em LCR de pacientes expostos à neurocirurgia (Camacho et al., 2013; Boszczowski e Bermudez 2016).

A presença de substâncias inibidoras da PCR no LCR pode causar resultados falso negativos por eletroforese (Favaro et al., 2013), podendo ser o motivo pelo qual uma das amostras apresentou cultura microbiana positiva e a PCR negativa. Entretanto, o contrário também ocorre, cultura microbiológica negativa e a PCR positiva, pois a carga bacteriana pode ser baixa para 0 crescimento na cultura, mas é suficiente para ser detectado pela biologia molecular.

Para um diagnóstico mais preciso de MAN é necessário a combinação de exames clínicos e laboratoriais do paciente. Os resultados da análise quimiocitológica do LCR: celularidade, proteína, lactato e glicose podem não ser indicadores confiáveis de infecção (Tunkel et al., 2017). No entanto, a análise microbiológica do LCR, cultura convencional e coloração de Gram são considerados o "padrão ouro" no diagnóstico da MAN (Muñoz-Gómez et al., 2015). Embora a cultura tenha uma baixa sensibilidade, especialmente quando a coleta do LCR é feita após a administração de antimicrobianos, e ainda demande pelo menos dois dias para ter um resultado, esta técnica continua a ser indispensável para a identificação e determinação do perfil de sensibilidade (Rose et al., 2010).

No entanto, a amplificação do DNA bacteriano por PCR é um método de detecção rápida com grande potencial para diagnosticar meningites bacterianas 
(Saravolatz et al., 2003). A PCR é geralmente considerada mais sensível que a cultura, uma vez que é possível detectar o DNA de bactérias vivas ou mortas (Kane; Alexander; Johannigman, 1998; Banks et al., 2005; Rose et al., 2010). Porém, a carga bacteriana e a sua viabilidade são fatores diretamente proporcionais à probabilidade de infecção, análise que não pode ser feita pelo PCR (Banks et al., 2005).

Estudos utilizam a cultura negativa do LCR como confirmação de uma meningite não bacteriana ou asséptica (Ramos-Martínez et al., 2009; Liu et al., 2014; Liu et al., 2015). A British Society for Antimicrobial Chemotherapy sugere que antibióticos empíricos introduzidos em pacientes com suspeita de meningite pós-operatória podem ser removidos com segurança entre 48h e 72h após uma cultura negativa (Zarrouk et al., 2007). Portanto, as ferramentas da biologia molecular como a PCR e o sequenciamento do gene 16S rRNA, podem ser grandes aliadas na identificação destes agentes microbiológicos causadores de MAN (Simon et al., 2014). 


\section{CONCLUSÃo}

- Os limites de detecção para bactérias Gram positivas e Gram negativas são respectivamente $10 \mathrm{UFC} / \mathrm{mL}$ e $10^{2} \mathrm{UFC} / \mathrm{mL}$.

- Houve predomínio de bactérias Gram negativas identificadas pelo sequencimento, demonstrando concordância com outros estudos que associam a frequência destas bactérias em LCR de pacientes expostos a neurocirurgia.

- A utilização de ferramentas da biologia molecular como a PCR e o sequenciamento do gene $16 \mathrm{~S}$ rRNA, podem ser grandes aliadas na identificação destes agentes microbiológicos causadores de MAN, podendo ser usadas como complemento no diagnóstico destas. 


\section{ANEXOS}

ANEXO A - Ficha Clínica desenvolvida para a pesquisa

\section{FICHA CLÍNICA}

\section{Número da Ficha:}

\section{IDENTIFICACCÃO}

Nomes:

RGHC: idade Sexo $M \square F \square$

\section{DADOS CLÍNICO-DEMOGRÁFICO}

1. Data admissão hospitalar

2. Paciente UTI $\square$ Enfermaria $\square$ Hospital:

3. Doença neurológica de base:

4. Indicação da cirurgia

5. Classificação da neurocirurgia

COMORBIDADES (presentes no momento do diagnóstico de meningite)

- Não infecciosos

\begin{tabular}{|c|c|c|c|c|c|c|c|c|c|}
\hline $\begin{array}{c}\text { Hipertensã } \\
\text { o arterial }\end{array}$ & $\begin{array}{c}\text { Hepatopati } \\
\text { a }\end{array}$ & $\begin{array}{c}\text { D } \\
\text { M }\end{array}$ & $\begin{array}{c}\text { IRA } \\
\text { crea } \\
\text { t }\end{array}$ & $\begin{array}{c}\text { IR } \\
\text { C }\end{array}$ & $\begin{array}{c}\text { Tumo } \\
\text { r de } \\
\text { órgão } \\
\text { sólido }\end{array}$ & $\begin{array}{c}\text { Leucose } \\
\text { s }\end{array}$ & $\begin{array}{c}\text { AID } \\
\text { S }\end{array}$ & $\begin{array}{c}\text { neutropeni } \\
\text { a }\end{array}$ & $\begin{array}{c}\text { Imunossupressã } \\
\text { o 2 2aria/ } \\
\text { medicamentosa }\end{array}$ \\
\hline & & & & & & & & & \\
\hline
\end{tabular}

- Infecciosas (14 dias antes ou após o diagx microbiológico de meningite)

\begin{tabular}{|c|c|c|c|c|c|c|c|}
\hline ICS & PAV & ITU & IAB & $\begin{array}{l}\text { Pele e } \\
\text { partes } \\
\text { moles }\end{array}$ & Sinusite & Endocardite & Outras \\
\hline & & & & & & & \\
\hline
\end{tabular}

Outros: 
6. Data da cirurgia

7. Data da suspeita diagnóstico de meningite (

8. Local da coleta do LCR:

9. Sintomas
a. $T \geq 37,8 \mathrm{C} \operatorname{sim}($ ) não ( )
b. Rigidez de nuca ( ) sim, ( ) não, ( ) não avaliável
c. Piora do Glagow (para pacientes não sedados):
$G$ na data da suspeita: ; $\mathrm{G} 48$ horas após:
d. Piora do Ramsay (para pacientes sedados):
$R$ na data da suspeita: R 48 horas após:

10. SOFA score na data da suspeita:

11. APACHE score na data da suspeita:

12. LCR

\begin{tabular}{|c|c|c|c|c|c|c|c|c|c|c|c|c|}
\hline Data & $\begin{array}{c}\text { No de } \\
\text { células }\end{array}$ & Hemácias & $\begin{array}{c}\text { Neutro } \\
\%\end{array}$ & Linfo $\%$ & Mono\% & Eosi\% & $\begin{array}{c}\begin{array}{c}\text { Proteína } \\
\mathrm{mg} / \mathrm{dl}\end{array} \\
\end{array}$ & Lactato & $\begin{array}{c}\text { Glicose } \\
\text { LCR }\end{array}$ & Cultura & $\begin{array}{c}\text { GLIC } \\
\text { sérica }\end{array}$ & $\begin{array}{c}\text { Glic } \\
\text { capilar }\end{array}$ \\
\hline & & & & & & & & & & & & \\
\hline & & & & & & & & & & & & \\
\hline & & & & & & & & & & & & \\
\hline & & & & & & & & & & & & \\
\hline & & & & & & & & & & & & \\
\hline & & & & & & & & & & & & \\
\hline & & & & & & & & & & & & \\
\hline & & & & & & & & & & & & \\
\hline & & & & & & & & & & & & \\
\hline & & & & & & & & & & & & \\
\hline & & & & & & & & & & & & \\
\hline & & & & & & & & & & & & \\
\hline & & & & & & & & & & & & \\
\hline & & & & & & & & & & & & \\
\hline
\end{tabular}

13. Data da cultura de LCR positiva

14. Resultado cultura de LCR: anexar

15. Culturas concomitantes (cinco dias antes ou após a suspeita de meningite) 
16. Óbito $\square \quad$ Cura/alta $\square \quad$ Data do desfecho (______

\section{TRATAMENTO}

\begin{tabular}{|c|c|c|c|c|}
\hline Terapia 1 & ATB1 & ATB2 & ATB3 & ATB4 \\
\hline Data de introdução & & & & \\
\hline ATBterapia & & & & \\
\hline Dose média/dia & & & & \\
\hline Data da retirada & & & & \\
\hline Terapia 2 & ATB1 & ATB2 & ATB3 & ATB4 \\
\hline Data de introdução & & & & \\
\hline ATBterapia & & & & \\
\hline Dose média/dia & & & & \\
\hline Data da retirada & & & & \\
\hline Terapia 3 & ATB1 & ATB2 & & \\
\hline Data de introdução & & & & \\
\hline ATBterapia & & & & ATB4 \\
\hline Dose média/dia & & & & \\
\hline Data da retirada & & ATB2 & & \\
\hline Terapia 4 & ATB1 & & & \\
\hline Data de introdução & & & & \\
\hline ATBterapia & & & & \\
\hline Dose média/dia & & & & \\
\hline Data da retirada & & & & \\
\hline
\end{tabular}

\section{Itens de orientação}

1. a doença neurológica de base pode ser dividida em três grandes grupos

- Vascular

- Hemorragia subaracnóide HSA (Fisher I, II, II e IV)

- Hemorragia subdural

- Hemorragia intraparenquimatosa (descrever se há inundação ventricular)

- Neoplásica

- Tumor(descrever o tipo de tumor) de fossa posterior

○ Tumor não fossa posterior

- Trauma

- Com fratura da base do crânio

- Sem fratura da base do crânio

OBS: a presença de fístula liquórica é um dado importante de ser relatada na condição neurológica de base

2. indicação da neurocirurgia - descrever o que está no diagnóstico pré-operatório da ficha de descrição cirúrgica

3. classificação da neurocirurgia - nome do procedimento descrito na ficha de descrição cirúrgica

4. comorbidades - doenças pré-existentes como hipertensão, diabetes, etc...

5. data do diagnóstico da meningite - a) data da coleta do LCR que fez o diagnóstico ou b) data do início da atbterapia quando se fez a suspeita 
ANEXO B - Parecer consubstanciado do Comitê de Ética

\section{HOSPITAL DAS CLIINICAS DA \\ FACULDADE DE MEDICINA DA Plotoforma USP - HCFMUSP}

\section{PARECER CONSUBSTANCIADO DO CEP}

\section{DADOS DO PROJETO DE PESQUISA}

Título da Pesquisa: Caracterização de meningites após neurocirurgia

Pesquisador: Anna Sara Shafferman Levin

Área Temática:

Versão:

CAAE: 30991914.4 .0000 .0068

Instituição Proponente:Hospital das Clínicas da Faculdade de Medicina da USP

Patrocinador Principal: Financiamento Próprio

\section{DADOS DO PARECER}

Número do Parecer: 657.493

Data da Relatoria: $21 / 05 / 2014$

\section{Apresentação do Projeto:}

Estudo descritivo que visa avaliar os principais agentes causadores de meningite pós-neurocirurgia (MPN) e através de técnicas de biologia molecular como metagenômica, PCR em tempo real, sequenciamento do gene 16S rRNA para bactérias, 18S e 28S rDNA para fungos será possível identificar agentes etiológicos de meningite não detectados por métodos convencionais de identificação laboratorial e avaliar a origem clonal e ancestralidade dos microrganismos envolvidos através do multilocus sequencing typing (MLST). Serão incluídas neste estudo 100 amostras de LCR de pacientes adultos submetidos à neurocirurgia em um hospital de ensino. Será realizada nos líquor dos pacientes: 1- Extração e purificação de DNA 2Padronização do PCR Multiplex para bactérias, fungos e vírus 3- Sequenciamento e identificação 4Identificação molecular direta de agentes cultiváveis causadores de meningite pós-neurocirurgia 5Padronização de PCR para microrganismos não cultiváveis convencionalmente 6- Comparação entre identificação microbiana laboratorial e molecular de microganismos cultiváveis em laboratório 7- Avaliação da diversidade genômica através Multilocus Sequence Typing (MLST)

\section{Objetivo da Pesquisa:}

Identificar agentes causadores de meningite pós-neurocirurgia, em especial, em casos no qual o LCR apresenta alteração, mas não há definição do agente microbiológico por métodos

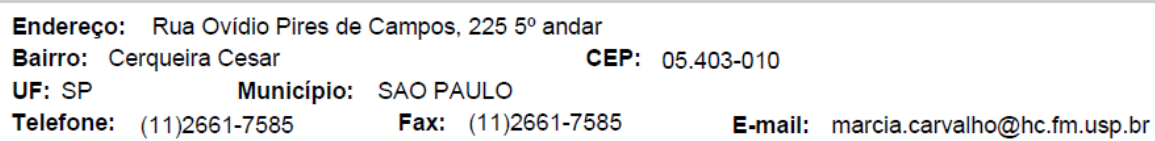




\section{HOSPITAL DAS CLÍNICAS DA FACULDADE DE MEDICINA DA USP - HCFMUSP}

Continuação do Parecer. 657.493

convencionais de laboratório, avaliando a sua prevalência, origem clonal e ancestralidade.

\section{Avaliação dos Riscos e Benefícios:}

Risco mínimo

Comentários e Considerações sobre a Pesquisa:

O tema é pertinente e a metodologia está adequada

O TCLE está claro

\section{Considerações sobre os Termos de apresentação obrigatória:}

O tema é pertinente e a metodologia está adequada

O TCLE está claro

\section{Recomendaçōes:}

Nenhuma

Conclusões ou Pendências e Lista de Inadequaçōes:

Nenhuma

Situação do Parecer:

Aprovado

Necessita Apreciação da CONEP:

Não

\section{Considerações Finais a critério do CEP:}

Em conformidade com a Resolução CNS n 466/12 - cabe ao pesquisador: a) desenvolver o projeto conforme delineado; b) elaborar e apresentar relatórios parciais e final; c)apresentar dados solicitados pelo CEP, a qualquer momento; d) manter em arquivo sob sua guarda, por 5 anos da pesquisa, contendo fichas individuais e todos os demais documentos recomendados pelo CEP; e) encaminhar os resultados para publicação, com os devidos créditos aos pesquisadores associados e ao pessoal técnico participante do projeto; f) justificar perante ao CEP interrupção do projeto ou a não publicação dos resultados.

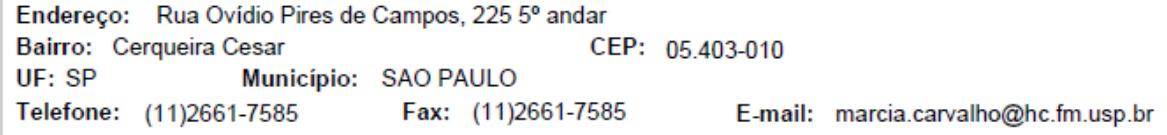


HOSPITAL DAS CLÍNICAS DA

FACULDADE DE MEDICINA DA USP - HCFMUSP

Continuação do Parecer: 657.493

SAO PAULO, 22 de Maio de 2014

Assinado por:

ALFREDO JOSE MANSUR

(Coordenador)

Endereço: Rua Ovídio Pires de Campos, $2255^{\circ}$ andar

$\begin{array}{ll}\text { Bairro: } & \text { Cerqueira Cesar } \\ \text { UF: SP } & \text { Município: SAO PAULO }\end{array}$

Telefone: (11)2661-7585 Fax: (11)2661-7585 E-mail: marcia.carvalho@hc.fm.usp.br

Página 03 de 03 
ANEXO C - Termo de consentimento livre e esclarecido aplicado na pesquisa HOSPITAL DAS CLÍNICAS DA FACULDADE DE MEDICINA DA UNIVERSIDADE DE SÃO PAULOHCFMUSP TERMO DE CONSENTIMENTO LIVRE E ESCLARECIDO

DADOS DE IDENTIFICAÇÃO DO SUJEITO DA PESQUISA OU RESPONSÁVEL LEGAL

1. NOME:.

DOCUMENTO DE IDENTIDADE № : SEXO : M ( ) F( )

DATA NASCIMENTO: ........................

ENDEREÇO № APTO:

BAIRRO: CIDADE

CEP: TELEFONE: DDD ..)

2.RESPONSÁVEL LEGAL

NATUREZA (grau de parentesco, tutor, curador etc.)

DOCUMENTO DE IDENTIDADE : SEXO: M( ) F（）

DATA NASCIMENTO.: ......................

ENDEREÇO: № APTO

BAIRRO: CIDADE:

CEP: TELEFONE: DDD (........)

\section{DADOS SOBRE A PESQUISA}

1. TÍTULO DO PROTOCOLO DE PESQUISA: “Caracterização de meningites pós-neurocirurgia” PESQUISADOR: Anna Sara S. Levin

CARGO/FUNÇÃO: Professora INSCRIÇÃO CONSELHO REGIONAL № .47966.

UNIDADE DO HCFMUSP: Neurocirurgia

3. AVALIAÇÃO DO RISCO DA PESQUISA:

$\begin{array}{ll}\text { RISCO MÍNIMO ( ) } & \text { RISCO MÉDIO ( ) } \\ \operatorname{RISCO} \operatorname{BAIXO}(X) & \text { RISCO MAIOR ( ) }\end{array}$

4.DURAÇÃO DA PESQUISA : 4 anos 
Prezado(a) participante ou responsável legal:

Você está sendo convidado a participar de um estudo sob supervisão da Prof(a) Dra. Anna Sara Shafferman Levin, cujo objetivo é identificar microrganismos causadores de meningite após uma cirurgia neurológica (no cérebro).

Sua participação envolve a autorização para o uso de material coletado por indicação de seu médico, uma amostra de líquor (de 1 a 2 mL - uma colher de café) que será obtida através de punção lombar (líquido retirado da coluna através de uma agulha), após a cirurgia. Os riscos são: dor de cabeça, dor ou desconforto na região lombar após o procedimento, infecção ou sangramento.

A sua contribuição será de grande importância para compreensão dos tipos de microrganismos possivelmente encontrados no líquor após cirurgia cerebral e assim ampliar o conhecimento científico sobre as causas da "infecção".

Você não terá benefícios diretos em participar desta pesquisa, mas indiretamente você estará contribuindo para a compreensão dos tipos de microrganismos possivelmente encontrados no líquor após uma cirurgia cerebral e para a produção de conhecimento científico. Somente ao final da pesquisa será possível concluir a presença de benefício para futuros pacientes.

A participação nesse estudo é voluntária e se você decidir não participar ou quiser desistir de continuar em qualquer momento, tem absoluta liberdade de fazê-lo sem que isto prejudique o seu cuidado médico.

Na publicação dos resultados desta pesquisa, sua identidade será mantida no mais rigoroso sigilo. Serão omitidas todas as informações que permitam identificá-lo(a).

Não haverá despesas pessoais para o participante em qualquer fase do estudo, incluindo exames e consultas. Como este estudo é voluntário, não há compensação financeira relacionada à sua participação.

O material doado, por ser nobre e de difícil coleta, contém informações que poderão ser utilizados em outras pesquisas no futuro.

Por isso, há necessidade de consultá-lo para autorizar o uso deste material doado em outras pesquisas científicas? 
( ) NÃO. Eu dispenso a autorização para cada pesquisa e estou informado(a) que a Comissão de Análise de Projetos de Pesquisa do Hospital das Clínicas (CAPPesq) irá examinar a nova pesquisa e decidir sobre a utilização ou não do material que eu estou doando.

( ) SIM. Eu quero ser consultado para a autorização a cada pesquisa futura com o meu material.

Quaisquer dúvidas relativas à pesquisa poderão ser esclarecidas pela pesquisadora Anna Sara S. Levin, encontrada no endereço Grupo de Controle de Infecção Hospitalar: Rua Ovidio Pires de Campos, 225, $6^{\circ}$ andar, sala 629 CEP: 05403-010; fone 2661 7066. Se você tiver alguma consideração ou dúvida sobre a ética da pesquisa, entre em contato com o Comitê de Ética em Pesquisa (CEP) - Rua Ovídio Pires de Campos, 225 - 5o andar - tel: 2661-6442 ramais 16, 17, 18 - e-mail: cappesq@hcnet.usp.br 


\section{HOSPITAL DAS CLÍNICAS DA FACULDADE DE MEDICINA DA UNIVERSIDADE DE SÃO PAULO-HCFMUSP \\ TERMO DE CONSENTIMENTO LIVRE E ESCLARECIDO}

Acredito ter sido suficientemente informado a respeito das informações que li ou que foram lidas para mim, descrevendo o estudo "Caracterização de meningites pós-neurocirurgia"

Eu discuti com Dr(a). Anna Sara S. Levin CRM: 47966, sobre a minha decisão em participar nesse estudo. Ficaram claros para mim quais são os propósitos do estudo, os procedimentos a serem realizados, seus desconfortos e riscos, as garantias de confidencialidade e de esclarecimentos permanentes. Ficou claro também que minha participação é isenta de despesas e que tenho garantia do acesso a tratamento hospitalar quando necessário. Concordo voluntariamente em participar deste estudo e poderei retirar o meu consentimento a qualquer momento, antes ou durante o mesmo, sem penalidades ou prejuízo ou perda de qualquer benefício que eu possa ter adquirido, ou no meu atendimento neste Serviço.

Assinatura do paciente/representante legal

Data / /

Assinatura da testemunha

Data / /

(para casos de pacientes menores de 18 anos, analfabetos, semi-analfabetos ou portadores de deficiência auditiva ou visual).

(Somente para o responsável do projeto)

Declaro que obtive de forma apropriada e voluntária o Consentimento Livre e Esclarecido deste paciente ou representante legal para a participação neste estudo.

Assinatura do responsável pelo estudo

Data / / 


\section{ANEXO D - Dados analisados dos pacientes submetidos a neurocirurgia e das amostras de LCR coletadas para a pesquisa}

\begin{tabular}{|c|c|c|c|c|c|c|c|c|c|c|c|c|c|c|c|c|c|c|c|c|}
\hline Paciente & Idade & Grupo & UNIDADE & $\begin{array}{l}\text { Data suspeita } \\
\text { da MAN }\end{array}$ & $\begin{array}{l}\text { Data coleta } \\
\text { LCR suspeita }\end{array}$ & Desfecho & Cultura & $\begin{array}{c}\text { Células } / \mathrm{m} \\
\mathrm{m}^{3}\end{array}$ & $\begin{array}{c}\text { Células } \\
/ \mathrm{mm}^{3} \\
\text { corrigidas }\end{array}$ & $\begin{array}{c}\text { № de } \\
\text { hemácias }\end{array}$ & $\begin{array}{c}\text { FCno } \\
\text { Células } / \mathrm{m} \\
\mathrm{m}^{3}\end{array}$ & $\begin{array}{c}\% \\
\text { NEU }\end{array}$ & $\begin{array}{l}\% \\
\text { LIN }\end{array}$ & $\begin{array}{c}\% \\
\text { MON }\end{array}$ & $\begin{array}{c}\% \\
\text { EOS }\end{array}$ & $\begin{array}{l}\text { Proteínas } \\
\mathrm{mg} / \mathrm{dL}\end{array}$ & $\begin{array}{l}\text { Lactato } \\
\mathrm{mg} / \mathrm{dL}\end{array}$ & $\begin{array}{l}\text { Glicose } \\
\mathrm{mg} / \mathrm{dL}\end{array}$ & PCR & Sequenciamento \\
\hline 1 & 39 & $4 \mathrm{~b}$ & $\mathrm{IPq}$ & $22 / 10 / 2015$ & $22 / 10 / 2015$ & 1 & Negativa & 17 & 15,4 & 1620 & 1,62 & 84 & 9 & 5 & - & 169 & 92,8 & 28 & + & $\begin{array}{c}\text { Granulicatella } \\
\text { adiacens }\end{array}$ \\
\hline 2 & 38 & 2 & ICHC-NEU & 10/06/2015 & 04/08/2015 & 1 & Negativa & 4950 & 4904,4 & 45600 & 45,6 & 97 & 1 & 2 & - & 377 & 80,2 & 11 & - & - \\
\hline 3 & 23 & $3 b$ & $\mathrm{IPq}$ & 29/03/2015 & $31 / 03 / 2015$ & 2 & Negativa & 100 & 96,1 & 3920 & 3,9 & 84 & 10 & 2 & 1 & 33 & 18 & 70 & + & $\begin{array}{c}\text { Granulicatella } \\
\text { adiacens }\end{array}$ \\
\hline 4 & 60 & $3 b$ & ICHC-TRA & $03 / 02 / 2015$ & $12 / 02 / 2015$ & 1 & Negativa & 247 & 246,4 & 639 & 0,64 & 6 & 86 & 6 & 1 & 64 & 26 & 45 & - & - \\
\hline 5 & 64 & $4 b$ & ICHC-TRA & $21 / 09 / 2015$ & $21 / 09 / 2015$ & 1 & Negativa & 22 & 22,0 & 6 & 0 & 2 & 78 & 20 & - & 231 & - & 206 & + & Sem consenso \\
\hline 6 & 74 & $4 a$ & ICHC-TRA & $26 / 11 / 2015$ & $26 / 11 / 2015$ & 1 & Negativa & 1 & 0,9 & 64 & 0,1 & - & - & - & - & 19 & 22,5 & 78 & + & Sem consenso \\
\hline 7 & 32 & $4 a$ & ICHC & $27 / 01 / 2015$ & $27 / 01 / 2015$ & 1 & Negativa & 7 & 1,3 & 5680 & 5,7 & 36 & 48 & 16 & - & 230 & 40,5 & 37 & + & $\begin{array}{l}\text { Variovorax } \\
\text { paradoxus }\end{array}$ \\
\hline 8 & 27 & $3 b$ & $\mathrm{IPq}$ & $23 / 08 / 2015$ & $23 / 08 / 2015$ & 1 & Negativa & 270 & 262,1 & 7950 & 7,9 & 82 & 13 & 4 & - & 88 & 25,2 & 47 & - & - \\
\hline 9 & 74 & $3 b$ & ICHC-NEU & 02/11/2015 & 02/11/2015 & 1 & Negativa & 45 & 44,7 & 285 & 0,3 & - & 95 & 3 & 1 & 57 & 25,2 & 106 & + & - \\
\hline 10 & 70 & $3 a$ & $\mathrm{IPq}$ & $17 / 01 / 2015$ & $18 / 01 / 2015$ & 1 & Negativa & 635 & 628,7 & 6266 & 6,3 & 7 & 81 & 10 & 1 & 108 & 31,5 & 50 & - & - \\
\hline 11 & 36 & $4 a$ & ICHC-TRA & 03/11/2015 & $04 / 11 / 2015$ & 1 & Negativa & 95 & 94,7 & 320 & 0,3 & 22 & 59 & 6 & 1 & 113 & 37,8 & 52 & + & $\begin{array}{c}\text { Acinetobacter } \\
\text { baumannii }\end{array}$ \\
\hline 12 & 20 & 2 & $\mathrm{IPq}$ & 09/01/2015 & $11 / 01 / 2015$ & 2 & Negativa & 720 & 706,4 & 13600 & 13,6 & 90 & 7 & 3 & - & 92 & 37,8 & 38 & + & $\begin{array}{c}\text { Variovorax } \\
\text { boronicumulans } \\
\end{array}$ \\
\hline 13 & 67 & $3 b$ & ICHC-TRA & $27 / 01 / 2016$ & $27 / 01 / 2016$ & 1 & Negativa & 87 & 50,7 & 36266 & 36,3 & 84 & 5 & 5 & 3 & 117 & 15,3 & 62 & + & - \\
\hline 14 & 21 & $4 a$ & $\mathrm{IPq}$ & $20 / 01 / 2015$ & 20/01/2015 & 1 & Negativa & 1 & 0,9 & 145 & 0,1 & 7 & 51 & 39 & 1 & 32 & 11,7 & 53 & - & - \\
\hline 15 & 49 & 1 & $\mathrm{IPq}$ & $21 / 03 / 2015$ & $21 / 03 / 2015$ & 1 & $\begin{array}{c}\text { Enterobacter } \\
\text { cloacae }\end{array}$ & 448 & 444,2 & 3840 & 3,8 & 24 & 15 & 59 & - & 224 & 92,8 & 98 & + & $\begin{array}{c}\text { Enterobacter } \\
\text { cloacae }\end{array}$ \\
\hline 16 & 31 & 2 & $\mathrm{IPq}$ & 20/06/2015 & 20/06/2015 & 2 & Negativa & 3840 & 3839,1 & 880 & 0,9 & 72 & 17 & 8 & - & 144 & 73 & 27 & + & $\begin{array}{c}\text { Variovorax } \\
\text { boronicumulans }\end{array}$ \\
\hline 17 & 20 & $4 a$ & ICHC-TRA & 06/10/2015 & 06/10/2015 & 2 & Negativa & 1 & 1,0 & 43 & 0 & 5 & 76 & 19 & - & 27 & 13,5 & 67 & - & - \\
\hline 18 & 61 & $4 a$ & $\mathrm{IPq}$ & $31 / 08 / 2015$ & $31 / 08 / 2015$ & 1 & Negativa & 2 & 1,9 & 140 & 0,1 & 4 & 90 & 5 & - & 40 & 18,9 & 62 & - & - \\
\hline 19 & 42 & 2 & $\mathrm{IPq}$ & $11 / 08 / 2015$ & $13 / 08 / 2015$ & 1 & Negativa & 3680 & 3679,2 & 810 & 0,8 & 70 & 10 & 16 & - & 179 & 61,3 & 34 & - & - \\
\hline 20 & 55 & $4 b$ & ICHC-TRA & 03/09/2015 & 03/09/2015 & 1 & Negativa & 50 & 26,4 & 76400 & 76,4 & 16 & 56 & 22 & - & 156 & 29,7 & 70 & - & - \\
\hline
\end{tabular}

FC: fator de correção; NEU: neutrófilos; LIN: linfócitos; MON: monócitos; EOS: eosinófilos 


\begin{tabular}{|c|c|c|c|c|c|c|c|c|c|c|c|c|c|c|c|c|c|c|c|c|}
\hline Paciente & Idade & Grupo & UNIDADE & $\begin{array}{l}\text { Data suspeita } \\
\text { da MAN }\end{array}$ & $\begin{array}{l}\text { Data coleta } \\
\text { LCR suspeita }\end{array}$ & Defecho & Cultura & $\begin{array}{c}\text { Células } / \mathrm{m} \\
\mathrm{m}^{3}\end{array}$ & $\begin{array}{c}\text { Células } \\
/ \mathrm{mm}^{3} \\
\text { corrigidas }\end{array}$ & $\begin{array}{c}\text { № de } \\
\text { hemácias }\end{array}$ & \begin{tabular}{|c|}
$\mathrm{FCn}$ - \\
Células $/ \mathrm{m}$ \\
$\mathrm{m}^{3}$ \\
\end{tabular} & $\begin{array}{c}\% \\
\text { NEU }\end{array}$ & $\begin{array}{c}\% \\
\text { LIN }\end{array}$ & $\begin{array}{c}\% \\
\text { MON }\end{array}$ & $\begin{array}{c}\% \\
\text { EOS }\end{array}$ & $\begin{array}{l}\text { Proteínas } \\
\mathrm{mg} / \mathrm{dL}\end{array}$ & $\begin{array}{l}\text { Lactato } \\
\mathrm{mg} / \mathrm{dL}\end{array}$ & $\begin{array}{l}\text { Glicose } \\
\mathrm{mg} / \mathrm{dL}\end{array}$ & PCR & Sequenciamento \\
\hline 21 & 70 & $3 b$ & GER-ICHC & 23/02/2015 & $24 / 02 / 2015$ & 2 & Negativa & 80 & - & 11 & - & 10 & 73 & 9 & 1 & 206 & 93,7 & 35 & - & - \\
\hline 22 & 71 & $4 \mathrm{~b}$ & ICHC-NEU & $20 / 01 / 2016$ & $21 / 01 / 2016$ & 1 & Negativa & 29 & 29,0 & 22 & 0 & 6 & 83 & 8 & - & 89 & 37,8 & 28 & - & - \\
\hline 23 & 43 & 1 & $\mathrm{IPq}$ & 29/01/2015 & $07 / 02 / 2015$ & 2 & $\begin{array}{c}\text { Staphylococcus } \\
\text { haemolyticus }\end{array}$ & 2450 & 2409,6 & 40400 & 40,4 & 89 & 3 & 5 & - & 365 & 118,9 & 43 & + & $\begin{array}{c}\text { Staphylococcus } \\
\text { haemolyticus }\end{array}$ \\
\hline 24 & 61 & $4 \mathrm{~b}$ & ICHC-TRA & $10 / 10 / 2015$ & 09/10/2015 & 1 & Negativa & 9 & 7,2 & 1835 & 1,8 & 22 & 55 & 20 & 2 & 600 & 45,9 & 57 & - & - \\
\hline 25 & 55 & $3 b$ & ICHC-NEU & 09/02/2015 & $14 / 02 / 2015$ & 2 & Negativa & 0 & $-0,5$ & 525 & 0,5 & $n$ & $n$ & $\mathrm{n}$ & $n$ & 10 & 26,1 & 146 & - & - \\
\hline 26 & 66 & $4 \mathrm{~b}$ & $\mathrm{IPq}$ & $21 / 10 / 2015$ & $26 / 10 / 2015$ & 1 & Negativa & 1 & $-2,9$ & 3880 & 3,9 & 7 & 78 & 15 & - & 64 & 17,1 & 62 & - & - \\
\hline 27 & 87 & 2 & ICHC-NEU & 28/08/2015 & 29/08/2015 & 1 & Negativa & 720 & 711,1 & 8880 & 8,9 & 71 & 5 & 9 & - & 217 & 39,6 & 82 & + & $\begin{array}{c}\text { Enterococcus } \\
\text { cecorum }\end{array}$ \\
\hline 28 & 40 & $4 \mathrm{~b}$ & $\mathrm{IPq}$ & $25 / 03 / 2015$ & $25 / 03 / 2015$ & 2 & Negativa & 35 & 20,3 & 14720 & 14,7 & 70 & 16 & 11 & 1 & 147 & 27 & 69 & - & - \\
\hline 29 & 42 & $4 \mathrm{~b}$ & ICHC-NEU & 20/09/2015 & 20/09/2015 & 1 & Negativa & 285 & 284,8 & 160 & 0,2 & 73 & 20 & 5 & - & 60 & 24,3 & 40 & + & \\
\hline 30 & 60 & 1 & $\mathrm{IPq}$ & $01 / 01 / 2015$ & $01 / 01 / 2015$ & 1 & $\begin{array}{c}\text { Klebsiella } \\
\text { pneumoniae }\end{array}$ & 240 & 229,6 & 10400 & 10,4 & 96 & 1 & - & - & 338 & 162,2 & 3 & + & $\begin{array}{c}\text { Klebsiella } \\
\text { pneumoniae }\end{array}$ \\
\hline 31 & 80 & $4 b$ & ICHC-NEU & $17 / 10 / 2015$ & $17 / 10 / 2015$ & 1 & Negativa & 320 & 318,4 & 1600 & 1,6 & 86 & 4 & 2 & 1 & 177 & 70,3 & 54 & + & $\begin{array}{l}\text { Escherichia } \\
\text { fergusonii }\end{array}$ \\
\hline 32 & 62 & $4 \mathrm{~b}$ & ICHC-NEU & $24 / 07 / 2015$ & $30 / 07 / 2015$ & 1 & Negativa & 13 & 12,9 & 139 & 0,1 & 10 & 5 & 68 & 1 & 28 & 31,5 & 67 & - & - \\
\hline 33 & 19 & $4 a$ & ICHC-TRA & 20/01/2016 & 20/01/2016 & 1 & Negativa & 84 & 83,6 & 415 & 0,4 & 18 & 56 & 12 & - & 67 & 20,7 & 96 & - & - \\
\hline 34 & 84 & $4 b$ & $\mathrm{IPq}$ & 23/03/2015 & 23/03/2015 & 2 & Negativa & 4 & $-0,2$ & 4160 & 4,2 & 79 & 18 & 3 & - & 133 & 22,5 & 87 & + & $\begin{array}{c}\text { Enterobacter } \\
\text { cloacae }\end{array}$ \\
\hline 35 & 65 & $4 \mathrm{~b}$ & ICHC & $16 / 08 / 2014$ & $18 / 08 / 2014$ & 2 & Negativa & 155 & 154,8 & 195 & 0,2 & 78 & 9 & 7 & 1 & 130 & 47 & 37,8 & + & - \\
\hline 36 & 60 & $4 b$ & ICHC-TRA & 17/09/2015 & 17/09/2015 & 2 & Negativa & 1200 & 768,0 & 432000 & 432 & 63 & 4 & 16 & - & 735 & 55 & 55 & + & $\begin{array}{l}\text { Escherichia } \\
\text { fergusonii }\end{array}$ \\
\hline 37 & 29 & $4 a$ & $\mathrm{IPq}$ & 07/01/2015 & 07/01/2015 & 1 & Negativa & 29 & 27,3 & 1680 & 1,7 & 2 & 78 & 13 & 5 & 567 & 70,3 & 7 & - & - \\
\hline 38 & 75 & $3 b$ & $\mathrm{IPq}$ & 29/10/2015 & 29/10/2015 & 1 & Negativa & 2 & 2,0 & 9 & 0 & 1 & 70 & 28 & 1 & 51 & 15,3 & 64 & + & $\begin{array}{c}\text { Pseudomonas } \\
\text { aeruginosa }\end{array}$ \\
\hline 39 & 62 & $3 b$ & ICHC-NEU & $24 / 10 / 2015$ & $24 / 10 / 2015$ & 1 & Negativa & 10 & $-0,5$ & 10500 & 10,5 & 83 & 7 & 9 & 1 & 25 & 24,3 & 111 & - & - \\
\hline 40 & 27 & 1 & $\mathrm{IPq}$ & 06/01/2016 & $05 / 01 / 2016$ & 1 & $\begin{array}{c}\text { Klebsiella } \\
\text { pneumoniae }\end{array}$ & 175 & 170,3 & 4720 & 4,7 & 23 & 50 & 24 & - & 194 & 66 & 24 & - & - \\
\hline 41 & 42 & $4 a$ & ICHC-NEU & $25 / 06 / 2015$ & $25 / 06 / 2015$ & 2 & Negativa & 14 & 14,0 & 28 & 0 & 17 & 68 & - & - & 52 & 26 & 45 & + & $\begin{array}{c}\text { Pseudomonas } \\
\text { aeruginosa }\end{array}$ \\
\hline 42 & 72 & $4 \mathrm{~b}$ & ICHC-NEU & 22/09/2015 & $22 / 09 / 2015$ & 1 & Negativa & 9 & 6,5 & 2453 & 2,5 & 46 & 52 & 2 & - & 85 & 26,1 & 64 & + & - \\
\hline 43 & 18 & $4 a$ & $\mathrm{IPq}$ & $01 / 04 / 2015$ & $01 / 04 / 2015$ & 1 & Negativa & 140 & 139,9 & 112 & 0,1 & 7 & 51 & 32 & 3 & 183 & 27,9 & 65 & + & Sem consenso \\
\hline
\end{tabular}

FC: fator de correção; NEU: neutrófilos; LIN: linfócitos; MON: monócitos; EOS: eosinófilos 
ANEXO E - Dificuldades enfrentadas durante a padronização e metodologias testadas

\section{- Padronizando a extração de DNA}

Inicialmente durante a pesquisa na literatura, o kit de extração de DNA mais utilizado para o LCR foi o QIAamp ${ }^{\circledR}$ DNA Mini Kit. No entanto, verificou-se que a quantificação de DNA extraído foi muito pequena, apesar das várias modificações feitas no protocolo de extração. Após os testes com o kit MagNA Pure Compact Nucleic Acid Isolation Kit I - Large ${ }^{\circledR}$ (Roche Diagnostics GmbH, Alemanha) verificou-se que as quantificações de DNA foram melhores.

\section{- Padronizando a reação de PCR do $16 S$ RNA ribossomal}

A padronização da reação de PCR do gene $16 S$ foi mais trabalhosa, pois existem detalhes minuciosos que devem ser levados em consideração devido à natureza do gene 16S RNA ribossomal bacteriano que está presente em todos os ambientes e materiais.

No total foram testados 6 diferentes pares de primers para a padronização da reação para o gene $16 \mathrm{~S}$ rRNA, desta maneira procurando aqueles mais adequados ao objetivo desta pesquisa.

Também foram testadas 2 combinações de reagentes em concentrações diferentes para o preparo do mix do PCR, e após a escolha da melhor combinação de concentração dos reagentes, foram feitos vários ajustes que incluíram dobrar o volume por reação, melhorando significativamente a reação de PCR. Na busca de melhor especificidade e eficiência da reação de PCR, foi testada uma reação com duas etapas denominada pela literatura de semi-nested PCR, onde não se observou um resultado satisfatório.

Além disso, foram testadas várias marcas de reagentes para a preparação de mix, entre elas:

- Platinum Taq DNA Polymerase High Fidelity - Thermo Fisher Scientific

- Platinum Taq DNA Polymerase - Thermo Fisher Scientific 
- HotStarTaq DNA Polymerase - Qiagen

A melhor marca de reagente para mix de PCR foi HotStarTaq DNA Polymerase da Qiagen pois não apresentou "banda fantasma" no controle negativo na foto da eletroforese, validando a reação, sendo confirmado por PCR em tempo real. Foram testados também diferentes, protocolos de amplificação para o gene 16S rRNA, com diferentes temperaturas de anelamento e número de ciclos até sua atual padronização.

\section{- Reduzindo a contaminação}

Para minimizar a frequente contaminação dos reagentes do mix do PCR por vestígios de DNA bacteriano, foi testado um protocolo já utilizando na literatura, a adição do reagente etídio-monoazida (EMA) ao mix do PCR e seguida por fotoativação (Patel et al., 2012). No entanto, verificou-se que houve grande perda de DNA das amostras testadas, o qual levou o abandono deste protocolo.

\section{- Sequenciamento de nova geração Plataforma lon Torrent PGM}

Foram selecionados 2 casos para o sequenciamento de nova geração através da plataforma lon Torrent PGM ${ }^{\mathrm{TM}}$ (Life Technologies), do gene 16S rRNA para bactérias, para sua posterior identificação. A amostra 1 é um LCR com cultura positiva e a amostra 2 é um LCR com cultura negativa.

A biblioteca foi feita pelo método de PCR de fusão, no qual foram feitas as seguintes etapas: amplificação das sequencias alvo, purificação $e$ quantificação do material genético que irá ser sequenciado e template. A preparação do template consiste de um PCR em 2 fases: aquosa e oleosa seguidas por uma fase de enriquecimento. A biblioteca foi colocada no aparelho Ion Torrent PGM ${ }^{\mathrm{TM}}$ (Life Technologies), que é um sistema de análise de DNA baseado no princípio de emissão e detecção de luz utilizando chips semicondutores abaixo da placa de sequenciamento, que é sensível a mudanças de $\mathrm{pH}$ no momento em que um nucleotídeo é incorporado. 
As amostras sequenciadas pela plataforma lon Torrent foram analisadas pelo software Torrent Suite ${ }^{\mathrm{TM}}$ e pelo software QIIME (Caporaso et.al., 2010).

Os dados em arquivo .fasta foram processados usando-se parâmetros no modo padrão. Foi aplicado um script para as etapas de demultiplexagem e filtragem de qualidade no QIIME, apropriados ao arquivo fastaq (comprimento mínimo de sequência = 200; pontuação mínima de qualidade média $=$ ou > que 30). O algoritmo USEARCH (Edgar, 2010), foi utilizado para realizar a filtragem de sequências ruidosas, verificação de quimeras, e OTUs (Operational Taxonomic Units), escolhendo $90 \%$ e $97 \%$ dos limiares de similaridade de sequência (em separado).

O arquivo de saída foi então usado para a escolha de um conjunto representativo de sequências utilizando o script pick_rep_set.py. A taxonomia foi atribuída utilizando-se a base de dados Greengenes (13_08) como uma referência no QIIME (assign_taxonomy.py). Os arquivos de saída (seqs_otu.txt e tax_assignments.txt) foram utilizados para construir uma tabela OTU (Formato BIOM) (make_otu_table.py). Além disso, a diversidade foi analisada através da execução de um fluxo de trabalho em QIIME, com o script core_diversity_analyses.py (Pylro et.al., 2014).

Também foi utilizado o pipeline UPARSE + QIIME. Este pipeline produziu dois arquivos de saída, OTUs em formato .txt e .table (Adicionalmente convertido .biomformat) e um conjunto de sequências representativas para cada OTU no formato FASTA. As sequências representativas em seguida, foram atribuídas a taxonomia usando uclust, e base de dados Greengenes (13_08) como uma referência em QIIME (assign_taxonomy.py). A análise da diversidade foi realizada através da execução de um fluxo de trabalho no QIIME, com o script core_diversity_analyses.py (Pylro et.al., 2014).

O sequenciamento gerou um conjunto de dados de 191863 sequências (em médias 95931,500 sequências por amostra) com fragmentos de aproximadamente 100 pares de base. As sequências de OTUs oram afiliadas a um nível de $97 \%$ de similaridade.

Foi feito a identificação taxonômica da sequência genética de cada OTU no qual foi comparada a três bancos de dados disponíveis na internet: Basic Local Alignment Search Tool (BLAST) www.ncbi.nlm.nhi.gov/blast/ (Liu et.al., 
2012); Ribosomal Database Project (RDP Release) http://rdp.cme.msu.edu/ (Wang et.al., 2007) e pelo Greengenes http://greengenes.lbl.gov/ (DeSantis et.al., 2006). Os algoritmos de busca foram mantidos na posição default para comparação com dados de sequências de RNA ribossômico 16S. Ao compararmos a identificação de 270 OTUs pelas três bases de dados foram observadas inconsistências na taxonomia para o gene 16S rRNA. Oitenta e uma discrepâncias foram verificadas na identificação das OTUs utilizando a ferramenta BLAST em comparação ao Greengenes. Esta inconsistência de resultados demostrou que esta metodologia não é satisfatória para o objetivo da pesquisa. 


\section{REFERÊNCIAS}

Ahmed FZ, Baig MW, Gascoyne-Binzi D, Sandoe JA. Enterococcus cecorum aortic valve endocarditis. Diagn Microbiol Infect Dis. 2011 Aug;70(4):525-7.

Alons IM, Verheul RJ, Kuipers I, Jellema K, Wermer MJ, Algra A, Ponjee G. Procalcitonin in cerebrospinal fluid in meningitis: a prospective diagnostic study. Brain Behav. 2016 Aug 16;6(11):e00545.

Banks JT, Bharara S, Tubbs RS, Wolff CL, Gillespie GY, Markert JM, Blount JP. Polymerase chain reaction for the rapid detection of cerebrospinal fluid shunt or ventriculostomy infections. Neurosurgery. 2005 Dec;57(6):1237-43;

Blaut M, Collins MD, Welling GW, Doré J, van Loo J, de Vos W. Molecular biological methods for studying the gut microbiota: the EU human gut flora project. Br J Nutr. 2002 May;87 Suppl 2:S203-11.

Boszczowski, Í, Vidal, JE. Meningites Bacterianas Pós-Operatórias em Neurocirurgia. In: Siqueira, Mario Gilberto; Sousa, Atos Alves de; Vellutini, Eduardo; Souza, Evandro César de; Machado, Fábio Santana; Machado, Helio Rubens; Azevedo-Filho, Hildo Cirne de; Kraemer, Jorge Luiz; Rotta, José Marcus; Teixeira, Manoel Jacobsen; Mizumoto, Nelson; Moraes, Osmar J. S.; Martins, Roberto Sergio; Faleiro, Rodrigo Moreira; Gusmão, Sebastião Nataniel Silva; Tzu, Wen Hung (eds). Tratado de neurocirurgia, v.2. BARUERI: Manole, 2016. p.2150-2158.

Bours PH, Polak R, Hoepelman Al, Delgado E, Jarquin A, Matute AJ. Increasing resistance in community-acquired urinary tract infections in Latin America, five years after the implementation of national therapeutic guidelines. Int $J$ Infect Dis. 2010 Sep;14(9):e770-4.

British Society for Antimicrobial Chemotherapy. The management of neurosurgical patients with postoperative bacterial or aseptic meningitis or external ventricular drain-associated ventriculitis. Infection in Neurosurgery Working Party of the British Society for Antimicrobial Chemotherapy. $\mathrm{Br} \mathrm{J}$ Neurosurg. 2000;14: 7-12

Caporaso JG, Kuczynski J, Stombaugh J, Bittinger K, Bushman FD, Costello EK, Fierer N, Peña AG, Goodrich JK, Gordon JI, Huttley GA, Kelley ST, Knights D, Koenig JE, Ley RE, Lozupone CA, McDonald D, Muegge BD, Pirrung M, Reeder J, Sevinsky JR, Turnbaugh PJ, Walters WA, Widmann J, Yatsunenko T, Zaneveld J, Knight R. QIIME allows analysis of highthroughput community sequencing data. Nat Methods. 2010 May;7(5):3356. doi: 10.1038/nmeth.f.303. Epub 2010 Apr 11.

Chang WN, Lu CH, Huang CR, Tsai NW, Chuang YC, Chang CC, et al., Changing epidemiology of adult bacterial meningitis in southern Taiwan: a hospitalbased study. Infection 2008;36: 15-22.

Chang CJ, Ye JJ, Yang CC, Huang PY, Chiang PC, Lee MH. Influence of thirdgeneration cephalosporin resistance on adult in-hospital mortality from postneurosurgical bacterial meningitis. J Microbiol Immunol Infect. 2010 Aug;43(4):301-9.

Chanteau S, Sidikou F, Djibo S, Moussa A, Mindadou H, Boisier P. Scaling up of PCR-based surveillance of bacterial meningitis in the African meningitis belt: indisputable benefits of multiplex PCR assay in Niger. Trans $R$ Soc Trop Med Hyg. 2006 Jul;100(7):677-80. 
Chanteau S, Rose AM, Djibo S, Nato F, Boisier P. Biological diagnosis of meningococcal meningitis in the African meningitis belt: current epidemic strategy and new perspectives. Vaccine. 2007 Sep 3;25 Suppl 1:A30-6.

Connolly KJ, Hammer SM. The acute aseptic meningitis syndrome. Infect Dis Clin North Am. 1990 Dec;4(4):599-622.

Codina MG, de Cueto M, Vicente D, Echevarría JE, Prats G. Microbiological diagnosis of central nervous system infections. Enferm Infecc Microbiol Clin. 2011 Feb;29(2):127-34.

Dąbrowski P, Jurkiewicz J, Czernicki Z, Koszewski W, Jasielski P. Polymerase chain reaction based detection of bacterial 16S rRNA gene in the cerebrospinal fluid in the diagnosis of bacterial central nervous system infection in the course of external cerebrospinal fluid drainage. Comparison with standard diagnostics currently used in clinical practice. Neurol Neurochir Pol. 2017 Sep - Oct;51(5):388-394.

Das S, Shibib DR, Vernon MO. The new frontier of diagnostics: Molecular assays and their role in infection prevention and control. Am J Infect Control. 2017 Feb 1;45(2):158-169.

Davis LE. Subacute and chronic meningitis. CONTINUUM: Lifelong Learning in Neurology: April 2006 - Volume 12 - Issue 2, Infectious Diseases - p 27-57

Delaunay E, Abat C, Rolain JM. Enterococcus cecorum human infection, France. New Microbes New Infect. 2015 Jun 15;7:50-1.

DeSantis TZ, Hugenholtz P, Larsen N, Rojas M, Brodie EL, Keller K, Huber T, Dalevi D, Hu P, Andersen GL. Greengenes, a chimera-checked 16S rRNA gene database and workbench compatible with ARB. Appl Environ Microbiol. 2006 Jul;72(7):5069-72.

Deutch S, Dahlberg D, Hedegaard J, Schmidt MB, Møller JK, Ostergaard L. Diagnosis of ventricular drainage-related bacterial meningitis by broad-range real-time polymerase chain reaction. Neurosurgery 2007; 61:306-12.

Drancourt M, Bollet C, Carlioz A, Martelin R, Gayral JP, Raoult D. 16S ribosomal DNA sequence analysis of a large collection of environmental and clinical unidentifiable bacterial isolates. J Clin Microbiol. 2000 Oct;38(10):3623-30.

Druel B, Vandenesch F, Greenland T, Verneau V, Grando J, Salord F, Christen $\mathrm{R}$, Etienne J. Aseptic meningitis after neurosurgery: a demonstration of bacterial involvement. Clin Microbiol Infect 1996; 1: 230-4.

Erdem I, Hakan T, Ceran N, Metin F, Akcay SS, Kucukercan M, Berkman MZ, Goktas P. Clinical features, laboratory data, management and the risk factors that affect the mortality in patients with postoperative meningitis. Neurol India. 2008 Oct-Dec;56(4):433-7

Espy MJ, Uhl JR, Sloan LM, Buckwalter SP, Jones MF, Vetter EA, Yao JD, Wengenack NL, Rosenblatt JE, Cockerill FR 3rd, Smith TF. Real-time PCR in clinical microbiology: applications for routine laboratory testing. Clin Microbiol Rev. 2006 Jan;19(1):165-256. Review. Erratum in: Clin Microbiol Rev. 2006 Jul;19(3):595.

Favaro M, Savini V, Favalli C, Fontana C. A multi-target real-time PCR assay for rapid identification of meningitis-associated microorganisms. Mol Biotechnol. 2013 Jan;53(1):74-9.

Figueiredo EG, Balasso GT, Teixeira MJ, Infecções em pós-craniotomias: revisão literária Arq Bras Neurocir 31(4): 219-23, 2012 
Foushee JA, Hope NH, Grace EE. Applying biomarkers to clinical practice: a guide for utilizing procalcitonin assays. J Antimicrob Chemother. 2012 Nov;67(11):2560-9.

Freney J, Gavini F, Ploton C, Leclerc H, Fleurette J. Isolation of Escherichia fergosonii from a patient with septicemia in France. Eur $J$ Clin Microbiol. 1987 Feb;6(1):78.

Funke G, Hany A, Altwegg M. Isolation of Escherichia fergusonii from four different sites in a patient with pancreatic carcinoma and cholangiosepsis. J Clin Microbiol. 1993 Aug;31(8):2201-3.

Gaastra W, Kusters JG, van Duijkeren E, Lipman LJ. Escherichia fergusonii. Vet Microbiol. 2014 Aug 6;172(1-2):7-12.

Gokhale VV, Therese KL, Bagyalakshmi R, Biswas J. Detection of Escherichia fergusonii by PCR-based DNA sequencing in a case of delayed-onset chronic endophthalmitis after cataract surgery. J Cataract Refract Surg. 2014 Feb;40(2):327-30.

Greisen K, Loeffelholz M, Purohit A, Leong D. PCR primers and probes for the 16S rRNA gene of most species of pathogenic bacteria, including bacteria found in cerebrospinal fluid. J Clin Microbiol. 1994 Feb;32(2):335-51.

Greub G, Devriese LA, Pot B, Dominguez J, Bille J. Enterococcus cecorum septicemia in a malnourished adult patient. Eur $J$ Clin Microbiol Infect Dis. 1997 Aug;16(8):594-8.

Heth JA. Neurosurgical aspects of central nervous system infections. Neuroimaging Clin N Am. 2012 Nov;22(4):791-9.

Howitz MF, Homøe $P$. The risk of acquiring bacterial meningitis following surgery in Denmark, 1996-2009: a nationwide retrospective cohort study with emphasis on ear, nose and throat (ENT) and neurosurgery. Epidemiol Infect. 2014 Jun;142(6):1300-9.

Hsueh PR, Teng LJ, Chen YC, Yang PC, Ho SW, Luh KT. Recurrent bacteremic peritonitis caused by Enterococcus cecorum in a patient with liver cirrhosis. J Clin Microbiol. 2000 Jun;38(6):2450-2.

Kallel H, Chelly H, Ghorbel M, Bahloul M, Ksibi H, Rekik N, Ben Mansour H, Bouaziz M. [Posttraumatic meningitis: incidence, bacteriology, and outcomes. Neurochirurgie. 2006 Nov;52(5):397-406.

Kane TD, Alexander JW, Johannigman JA. The detection of microbial DNA in the blood: a sensitive method for diagnosing bacteremia and/or bacterial translocation in surgical patients. Ann Surg. 1998 Jan;227(1):1-9.

Kelly ME, Fourney DR, Guzman R, Sadanand V, Griebel RW, Sanche SE.

Propionibacterium acnes infections after cranial neurosurgery. Can J Neurol Sci. 2006 Aug;33(3):292-5.

Lai CC, Cheng A, Huang YT, Chung KP, Lee MR, Liao $\mathrm{CH}$, Hsueh PR. Escherichia fergusonii bacteremia in a diabetic patient with pancreatic cancer. J Clin Microbiol. 2011 Nov;49(11):4001-2.

Lagacé-Wiens PR, Baudry PJ, Pang P, Hammond G. First description of an extended-spectrum-beta-lactamase-producing multidrug-resistant Escherichia fergusonii strain in a patient with cystitis. J Clin Microbiol. 2010 Jun;48(6):2301-2.

Lawrence JG, Ochman H, Hartl DL. Molecular and evolutionary relationships among enteric bacteria. J Gen Microbiol. 1991 Aug;137(8):1911-21 
Levinson W, Microbiologia médica e imunologia. 13. ed. Porto Alegre: AMGH, 2016. Pagina 590.

Liu L, Li Y, Li S, Hu N, He Y, Pong R, Lin D, Lu L, Law M. Comparison of nextgeneration sequencing systems. J Biomed Biotechnol. 2012:251364

Liu Y-J, Shao L-H, Wang Q, Zhang J, Ma R-P, Liu H-H, Dong X-M, Ma L-X. Predictive Value of decoy receptor 3 in postoperative nosocomial bacterial meningitis. Int J Mol Sci 2014; 15: 19962-70.

Liu Z-H, Tu P-H, Chen N-Y, Yip PK, Bowes AL, Lee C-C, Chan S-H, Kung C-C, Wang A Y-C, Wu C-T, Lee S-T. Raised proinflammatory cytokine production within cerebrospinal fluid precedes fever onset in patients with neurosurgeryassociated bacterial meningitis. Neurologic Crit Care 2015; 43: 2416-28

López-Cortés LF, Marquez-Arbizu R, Jimenez-Jimenez LM, Jimenez-Mejías E, Caballero-Granado FJ, Rey-Romero C, Polaina M, Pachón J. Cerebrospinal fluid tumor necrosis factor-alpha, interleukin-1beta, interleukin-6, and interleukin-8 as diagnostic markers of cerebrospinal fluid infection in neurosurgical patients. Crit Care Med. 2000 Jan;28(1):215-9.

Ludwig W, Schleifer KH. Bacterial phylogeny based on $16 \mathrm{~S}$ and $23 \mathrm{~S}$ rRNA sequence analysis. FEMS Microbiol Rev. 1994 Oct;15(2-3):155-73. Review.

Mandell GL, Douglas RG, Bennett JE Dolin R. Principles and practice of infectious disease. $7^{\underline{a}}$ ed. Philadelphia. Churchill Livingstone Ed. 2010. p: 1183-1229

Maskin LP, Capparelli F, Mora A, Hlavnicka A, Orellana N, Díaz MF, Wainsztein $\mathrm{N}$, Del Castillo M. Cerebrospinal fluid lactate in post-neurosurgical bacterial meningitis diagnosis. Clin Neurol Neurosurg 2013; 115: 1820-25

McClelland S 3rd. Postoperative intracranial neurosurgery infection rates in North America versus Europe: a systematic analysis. Am J Infect Control. 2008 Oct;36(8):570-3.

Miwa H, Ahmed I, Yoon J, Yokota A, Fujiwara T. Variovorax boronicumulans sp. nov., a boron-accumulating bacterium isolated from soil. Int $J$ Syst Evol Microbiol. 2008 Jan;58(Pt 1):286-9.

Muñoz-Gómez S, Wirkowski E, Cunha BA. Post craniotomy extra-ventricular drain (EVD) associated nosocomial meningitis: CSF diagnostic criteria. Heart Lung. 2015 Mar-Apr;44(2):158-60.

Nadkarni MA, Martin FE, Jacques NA, Hunter N. Determination of bacterial load by real-time PCR using a broad-range (universal) probe and primers set. Microbiology. 2002 Jan;148(Pt 1):257-66.

O'Brien D, Stevens NT, Lim CH, O'Brien DF, Smyth E, Fitzpatrick F, Humphreys $\mathrm{H}$. Candida infection of the central nervous system following neurosurgery: a 12-year review. Acta Neurochir (Wien). 2011 Jun;153(6):1347-50.

Patel P, Garson JA, Tettmar KI, Ancliff S, McDonald C, Pitt T, Coelho J, Tedder RS. Development of an ethidium monoazide-enhanced internally controlled universal 16S rDNA real-time polymerase chain reaction assay for detection of bacterial contamination in platelet concentrates. Transfusion. 2012 Jul;52(7):1423-32.

Parisi SG, Basso M, Del Vecchio C, Andreis S, Franchin E, Dal Bello F, Pagni S, Biasolo MA, Manganelli R, Barzon L, Palù G. Viral infections of the central nervous system in elderly patients: a retrospective study. Int J Infect Dis. 2016 Jan 25; 44:8-10. 
Pylro VS, Roesch LF, Morais DK, Clark IM, Hirsch PR, Tótola MR. Data analysis for $16 \mathrm{~S}$ microbial profiling from different benchtop sequencing platforms. $J$ Microbiol Methods. 2014 Dec;107:30-7.

Ramos-Martínez A, de Las Heras-Carballo T, Fernández-Mateos C, de Reina L, Alvarez de Espejo-Montiel T, Escamilla-Fernández N, Sánchez-Romero I, Millán I. Postsurgical meningitis. Differential characteristics of aseptic postsurgical meningitis. Neurocirugia (Astur). 2009 Apr;20(2):103-9.

Rath PM, Schoch B, Adamzik M, Steinmann E, Buer J, Steinmann J. Value of multiplex PCR using cerebrospinal fluid for the diagnosis of ventriculostomyrelated meningitis in neurosurgery patients. Infect 2014; 42: 621-7.

Riddell $\mathrm{J}$ 4th, Shuman EK. Epidemiology of central nervous system infection. Neuroimaging Clin N Am. 2012 Nov;22(4):543-56.

Robbins JB, Schneerson R, Gotschlich EC. Surveillance for bacterial meningitis by means of polymerase chain reaction. Clin Infect Dis. 2005 Jan 1;40(1):267.

Rose AM, Mueller JE, Gerstl S, Njanpop-Lafourcade BM, Page AL, Nicolas P, Traoré RO, Caugant DA, Guerin PJ. Meningitis dipstick rapid test: evaluating diagnostic performance during an urban Neisseria meningitidis serogroup $A$ outbreak, Burkina Faso, 2007. PLoS One. 2010 Jun 11;5(6): e11086.

Roos, KL. Acute meningitis. CONTINUUM: Lifelong Learning in Neurology: April 2006 - Volume 12 - Issue 2, Infectious Diseases - p 13-26

Sacchi CT, Fukasawa LO, Gonçalves MG, Salgado MM, Shutt KA, Carvalhanas TR, Ribeiro AF, Kemp B, Gorla MC, Albernaz RK, Marques EG, Cruciano A, Waldman EA, Brandileone MC, Harrison LH; São Paulo RT-PCR Surveillance Project Team. Incorporation of real-time PCR into routine public health surveillance of culture negative bacterial meningitis in São Paulo, Brazil. PLoS One. 2011;6(6):e20675

Salord F, Druel B, Grando J, Verneau V, Perret C, Vandenesch F, Etienne J, Chacornac R. Aseptic meningitis. Demonstration of bacterial DNA in cerebrospinal fluid by gene amplification. Ann Fr Anesth Reanim. 1995; $14: 320-5$

Saravolatz LD, Manzor O, VanderVelde N, Pawlak J, Belian B. Broad-range bacterial polymerase chain reaction for early detection of bacterial meningitis. Clin Infect Dis. 2003 Jan 1;36(1):40-5.

Savini V, Catavitello C, Talia M, Manna A, Pompetti F, Favaro M, Fontana C, Febbo F, Balbinot A, Di Berardino F, Di Bonaventura G, Di Zacomo S, Esattore F, D'Antonio D. Multidrug-resistant Escherichia fergusonii: a case of acute cystitis. J Clin Microbiol. 2008 Apr;46(4):1551-2

Schade RP, Schinkel J, Roelandse FW, Geskus RB, Visser LG, van Dijk JM, Voormolen $\mathrm{JH}$, Van Pelt $\mathrm{H}$, Kuijper EJ. Lack of value of routine analysis of cerebrospinal fluid for prediction and diagnosis of external drainage related bacterial meningitis. J Neurosurg. 2006 Jan;104(1):101-8.

Seehusen DA, Reeves MM, Fomin DA. Cerebrospinal fluid analysis. Am Fam Physician. 2003 Sep 15;68(6):1103-8.

Sibley CD, Peirano G, Church DL. Molecular methods for pathogen and microbial community detection and characterization: current and potential application in diagnostic microbiology. Infect Genet Evol. 2012 Apr;12(3):505-21. 
Simon TD, Pope CE, Browd SR, Ojemann JG, Riva-Cambrin J, Mayer-Hamblett N, Rosenfeld M, Zerr DM, Hoffman L. Evaluation of microbial bacterial and fungal diversity in cerebrospinal fluid shunt infection. PLoS One. 2014 Jan 8;9(1): e 83229.

Tacon CL, Flower O. Diagnosis and management of bacterial meningitis in the paediatric population: a review. Emerg Med Int. 2012:320309.

Takeuchi F, Watanabe S, Baba T, Yuzawa H, Ito T, Morimoto Y, Kuroda M, Cui L, Takahashi M, Ankai A, Baba S, Fukui S, Lee JC, Hiramatsu K. Wholegenome sequencing of staphylococcus haemolyticus uncovers the extreme plasticity of its genome and the evolution of human-colonizing staphylococcal species. J Bacteriol. 2005 Nov;187(21):7292-308.

Tannock GW. Analysis of the intestinal microflora using molecular methods. Eur J Clin Nutr. 2002 Dec;56 Suppl 4: S44-9.

Tavares WM, Machado AG, Matushita H, Plese JP. CSF markers for diagnosis of bacterial meningitis in neurosurgical postoperative patients. Arq Neuropsiquiatr. 2006 Sep;64(3A):592-5.

Tortora GJ, Funke BR, Case CL. Microbiologia. 10. ed., Porto Alegre: Artmed, 2012.

Tunkel AR, Hartman BJ, Kaplan SL, Kaufman BA, Roos KL, Scheld WM, Whitley RJ. Practice guidelines for the management of bacterial meningitis. Clin Infect Dis. 2004 Nov 1;39(9):1267-84.

Tunkel AR, Hasbun R, Bhimraj A, Byers K, Kaplan SL, Michael Scheld W, van de Beek D, Bleck TP, Garton HJ, Zunt JR. 2017 Infectious Diseases Society of America's Clinical Practice Guidelines for Healthcare-Associated Ventriculitis and Meningitis. Clin Infect Dis. 2017

Van Pelt-Verkuil E, Van Belkum A, Hays JP. Principles and technical aspects of PCR amplification. Springer Verlag, Berlin; 2008.

Van de Beek D, Drake JM, Tunkel AR. Nosocomial bacterial meningitis. N Engl $J$ Med. 2010 Jan 14;362(2):146-54.

Veronesi R., Focaccia R. Tratado de Infectologia. 4ํㅡㄹ ed. São Paulo: Ed Atheneu; 2010. p.1141-1181.

Vichi CPBC. Meningite pós-neurocirurgia: evolução clínica e fatores de risco para mortalidade. Dissertação de mestrado, Faculdade de Medicina da Universidade de São Paulo, 2004.

Wang KW, Chang WN, Huang CR, Tsai NW, Tsui HW, Wang HC, Su TM, Rau CS, Cheng BC, Chang CS, Chuang YC, Liliang PC, Tsai YD, Lu CH. Postneurosurgical nosocomial bacterial meningitis in adults: microbiology, clinical features, and outcomes. J Clin Neurosci. 2005 Aug;12(6):647-50.

Wang Q, Garrity GM, Tiedje JM, Cole JR. Naive Bayesian classifier for rapid assignment of rRNA sequences into the new bacterial taxonomy. Appl Environ Microbiol. 2007 Aug;73(16):5261-7.

Woese CR. Bacterial evolution. Microbiol Rev. 1987 Jun;51(2):221-71. Review.

Woese CR, Kandler O, Wheelis ML. Towards a natural system of organisms: proposal for the domains Archaea, Bacteria, and Eucarya. Proc Natl Acad Sci USA. 1990 Jun;87(12):4576-9.

Won H, Yang S, Gaydos C, Hardick J, Ramachandran P, Hsieh YH, Kecojevic A, Njanpop-Lafourcade BM, Mueller JE, Tameklo TA, Badziklou K, Gessner BD, Rothman RE. A broad range assay for rapid detection and etiologic 
characterization of bacterial meningitis: performance testing in samples from sub-Sahara. Diagn Microbiol Infect Dis. 2012 Sep;74(1):22-7.

Woo PC, Tam DM, Lau SK, Fung AM, Yuen KY. Enterococcus cecorum empyema thoracis successfully treated with cefotaxime. J Clin Microbiol. $2004 \mathrm{Feb}$;2(2):919-22.

Yang S, Rothman RE. PCR-based diagnostics for infectious diseases: uses, limitations, and future applications in acute-care settings. Lancet Infect Dis. 2004 Jun;4(6):337-48.

Yarza P, Yilmaz P, Pruesse E, Glöckner FO, Ludwig W, Schleifer KH, Whitman WB, Euzéby J, Amann R, Rosselló-Móra R. Uniting the classification of cultured and uncultured bacteria and archaea using 16S rRNA gene sequences. Nat Rev Microbiol. 2014 Sep;12(9):635-45.

Zarrouk V, Vassor I, Bert F, Bouccara D, Kalamarides M, Bendersky N, Redondo A, Sterkers O, Fantin B. Evaluation of the management of postoperative aseptic meningitis. Clin Infect Dis 2007; 44:1555-9

Zarrouk V, Leflon-Guibout V, Robineaux S, Kalamarides M, Nicolas-Chanoine $\mathrm{MH}$, Sterkers O, Fantin B. Broad-range 16S rRNA PCR with cerebrospinal fluid may be unreliable for management of postoperative aseptic meningitis. J Clin Microbiol 2010; 48: 3331-3 